J. H. WESTERMANN

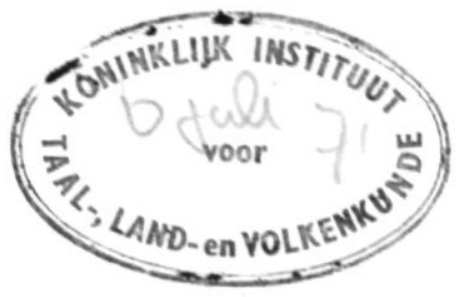

\title{
HISTORISCH OVERZICHT VAN DE WORDING EN HET ONDERZOEK VAN HET BROKOPONDO-STUWMEER
}

\begin{abstract}
Man-made lakes or reservoirs are usually built for some primary purpose, but the construction or presence of reservoirs can create secondary problems which may involve economic loss and human suffering unless reservoir planning in its earliest stages thoroughly considers both primary and secondary aspects.

Man-made lakes, FAO 1969
\end{abstract}

I. TECHNISCHE EN ECONOMISCHE ASPECTEN

2. NATUURWETENSCHAPPELIJKE, MEDISCHE EN SOCIOLOGISCHE ASPECTEN

3. HET NATUURWETENSCHAPPELIJK ONDERZOEK, I962-I969

4. BIBLIOGRAFIE

a. Technische en economische aspecten

b. Natuurwetenschappelijke, medische en sociologische aspecten

c. Het natuurwetenschappelijk onderzoek

1.

TECHNISCHE EN ECONOMISCHE ASPECTEN

In I924-1925 was voor de eerste keer in Suriname sprake van opwekking van waterkracht en wel ten behoeve van een door de SURINAAMSCHE BAUXITE MAATSCHAPPIJ te bouwen aluminiumfabriek. Amerikaanse ingenieurs achtten toen alleen de Marowijne daarvoor geschikt. Mede omdat het hier een grensrivier betreft en doordat de maatschappij zich kon verzekeren van de energie van een in de U.S.A. in aanbouw zijnde waterkrachtcentrale is toen van het Surinaamse project niets gekomen.

Nadat begin I950 door Prof. Ir. W. F. Eysvoogel opnieuw was gewezen op de mogelijkheid om de Surinaamse rivieren 
dienstbaar te maken voor het opwekken van hydro-electriciteit, kwam op 28 augustus 1950 het rapport van Prof. Dr. Ir. W. J. van Blommestein, die door Dr. E. J. À CAmpo van de Economisch-Financiële Sector van het Coördinatie College SuRINAME was uitgenodigd terzake advies uit te brengen. Grotendeels op basis van de met fondsen van het Welvaartsplan in 1948 en I949 door het Cartografisch Bedrijf van de KLM (Delft) gemaakte luchtkartering ten noorden van de 4 de breedtegraad ontwierp VAN Blommestein Een combinatie-plan voor de Suriname-rivier. Door een koppeling van de stroomgebieden van de Lucie-rivier, de Tapanahony en de Suriname-rivier en de constructie van een I5-tal dammen zou een jaarenergie van ruim 7 milliard kilowattuur bereikt kunnen worden. Behalve van die waterkrachtopwekking zou Suriname kunnen profiteren van een goede scheepvaartverbinding van de kust naar het binnenland, van irrigatie en van een grotere zoetwatervisvangst.

In een uitvoerige nota van juli I95I kwam EysvoogeL terug op het vraagstuk van de energievoorziening (zie ook zijn populaire artikel van I95I).

$\mathrm{Al}$ eerder, in februari I95I, werd Ir. R. ZONNEveld door het Coördinatie College Suriname - op 30 juli I95I vervangen door de Stichting Planbureau Suriname - voor het doen van terreinonderzoek naar Suriname uitgezonden en belast met het verrichten van verkenningen, uitvoeren van barometrische hoogtemetingen ten behoeve van de aero-triangulatie van het stuwmeergebied, het plaatsen van zelfregistrerende peilschalen en regenmeters te Brokopondo aan de Suriname-rivier en te Affivisiti aan de Tapanahony, het doen van debietmetingen in de Suriname-rivier en het verrichten van waterpassingen langs mogelijke tracé's van secundaire dammen.

Door het CARTOGRAFISCH BEDRIJf VAN DE K.L.M. was medio I950 begonnen met het in kaart brengen op schaal I : ro.000 van het stuwmeergebied en omgeving (totaal ca. 4500 vierkante kilometer).

Toen bleek dat ter weerszijden van de in eerste instantie gekozen stuwdamlocatie Brokopondo de secundaire dammen aanzienlijk langer en hoger zouden moeten worden gemaakt dan oorspronkelijk was geraamd, werd ultimo I95I besloten een vermoedelijk betere locatie te kiezen en wel 'Sara', 8 kilometer bovenstrooms van Brokopondo en even benedenstrooms van de uitmonding van de Sarakreek in de Suriname-rivier; later werd aan deze locatie de reeds bij de bevolking bekende naam Afobaka ge- 


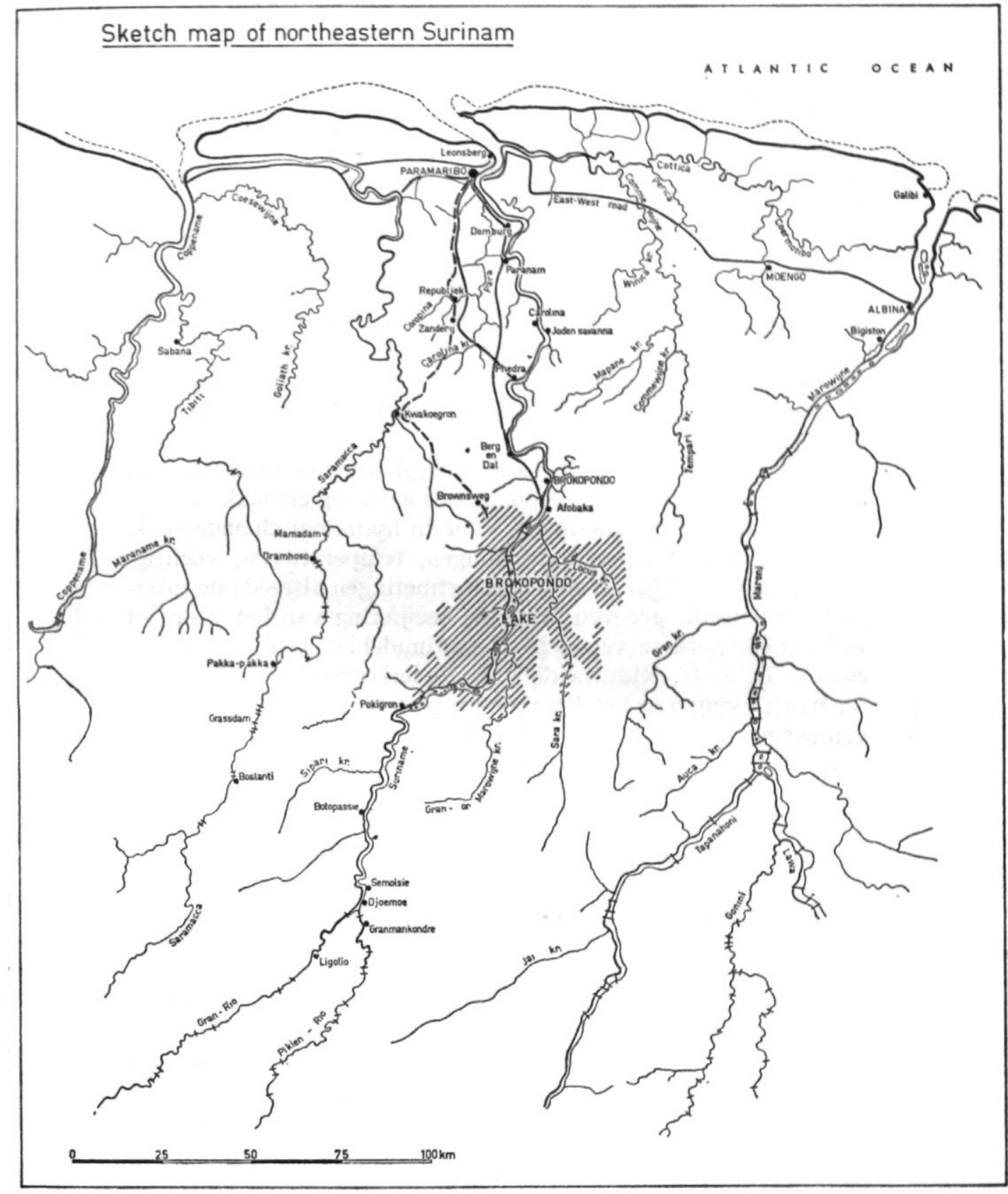

Fig. I. Schetskaartje van noordoostelijk Suriname waarin de ligging van het Brokopondo-stuwmeer is aangegeven. (Naar een afbeelding uit een rapport van P. LEENTVAaR). 
geven. Hier zou weliswaar de hoofddam langer en hoger zijn dan bij Brokopondo, d.w.z. ca. I50o meter, maar het aantal secundaire dammen geringer.

In mei I95I werden door de Geologisch MijnbouwkUndige Dienst, Paramaribo, twee veldploegen ingezet voor geologisch onderzoek in het stuwmeergebied en voor funderingsonderzoek van de hoofd- en secundaire damlocaties en de natuurlijke waterkeringen. Grond- en boormonsters werden voor de beoordeling van hun geschiktheid als dambouwmateriaal opgezonden naar het Laboratorium voor Grondmechanica te Delft. De G.M.D. stelde van de tot I september 1952 verkregen resultaten een omvangrijk rapport op, gedagtekend ro oktober I952. Het onderzoek van het stuwmeergebied bracht geen belangrijke ertsvoorkomens aan het licht.

Op I augustus I95I werden de zelfregistrerende peilschalen in werking gesteld en bij Brokopondo een aanvang gemaakt met de geregelde waterdebietmetingen. Voor dit hydrologisch onderzoek, mede omvattend regenwaarnemingen, temperatuurs-, vochtigheids-, verdampings- en slibtransportmetingen alsmede de interpretatie van alle gegevens voor de becijfering van het voor het waterkrachtwerk te verwachten continudebiet, werd medio december Ir. S. H. Ringma door de Nederlandse Rijkswaterstaat ter beschikking van het Planbureau gesteld, nadat hij op Io november een werkprogramma had ingezonden.

In 1952 werd het aantal regenstations belangrijk uitgebreid en werden, behalve de dagelijkse debietmetingen bij Brokopondo, incidentele afvoermetingen te Pokigron en Semoissi verricht. In het bos bij Semoissi werden metingen gedaan van het percentage van de neerslag dat de bodem bereikt (ongeveer $75 \%$ van de totale regenval). Te Brokopondo werd de verdamping van een vrij wateroppervlak gemeten: bij een regenval van $2273 \mathrm{~mm}$ per jaar was er een verdamping van gemiddeld 3,3 $\mathrm{mm}$ per etmaal, d.i. ca. I200 $\mathrm{mm}$ per jaar. De jaarlijkse slib- en zandafvoer bleek bij Brokopondo slechts 7000 kubieke meter groot te zijn zodat geen gevaar zou bestaan voor dichtslibbing van het stuwmeer. RINGMA rapporteerde aanvankelijk in zijn Hydrologische Nota's $I$ (4 juni I952), 2 (26 juli), 3 (I9 augustus), 4 (oktober) en 5 (24 januari I953, Eindverslag afvoerjaar 1952). Het laatste verslag geeft, ondanks de korte waarnemingsperiode, een fraai en gedegen overzicht - in tekst, kaarten, grafieken en tabellen - van o.a. het rivierverval, de waterstanden en -afvoeren, neerslag, verdamping, kwel, en transport van slib en zand. Na zijn eervol ontslag op 


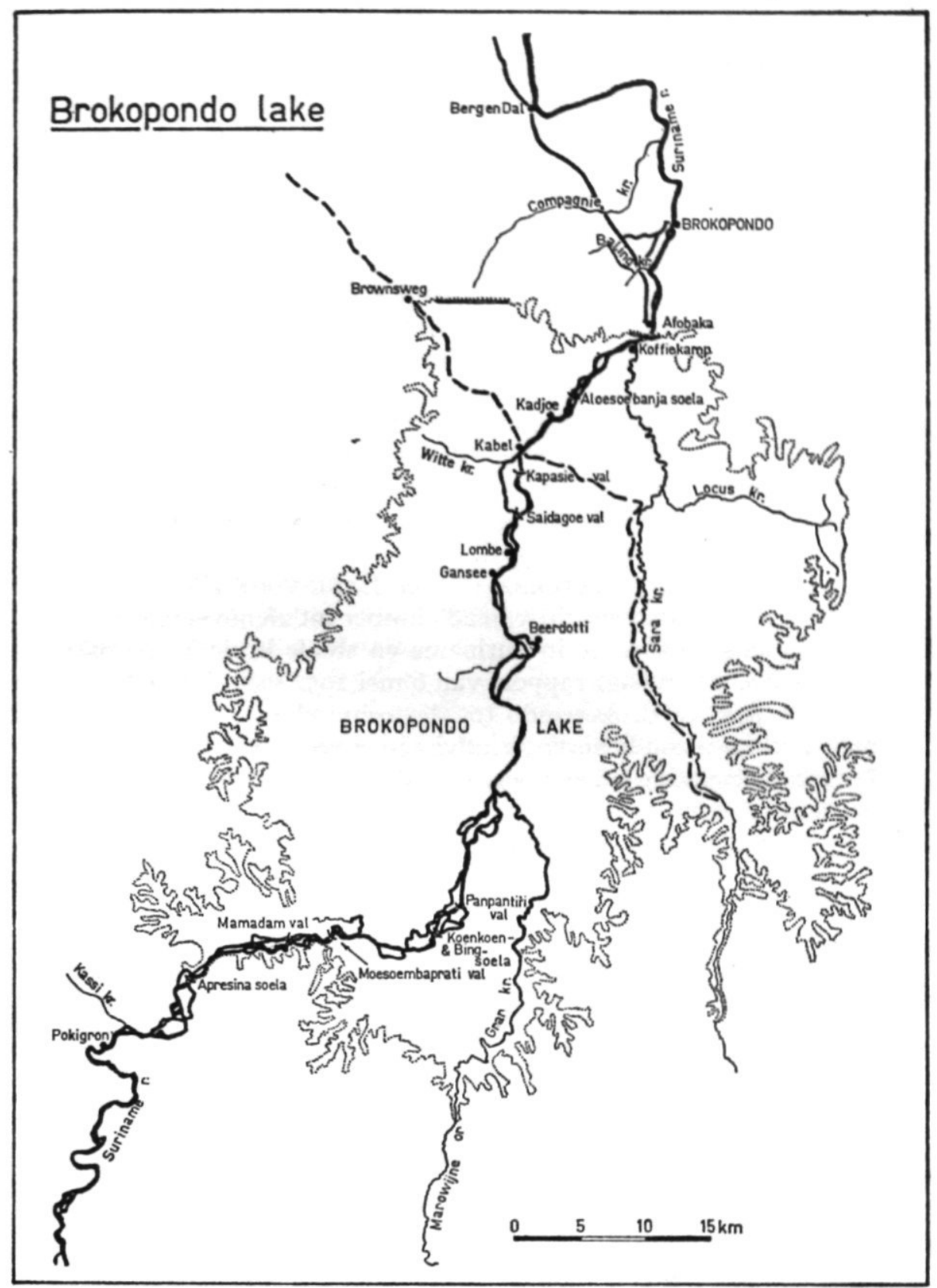

Fig. 2. Schetskaartje van de omtrek van het Brokopondo-stuwmeer waarin de grillige contouren en de talrijke eilanden niet zijn aangegeven. (Naar een afbeelding uit een rapport van P. LEentVAaR). 
28 februari 1953 schreef hij in Nederland zijn Nota No. 6 (I953) waarin hij tot de conclusie kwam dat de regenval ter plaatse van de damlocatie geen bezwaar behoefde te vormen voor de bouw van een aarden dam.

De genoemde stuwdamvooronderzoekingen - sedert I augustus I95I onder de algemene leiding van Ir. L. van GEUNS, te werk gesteld op het Planbureau te 's-Gravenhage - werden beschreven in de Bijlagen A bij de Jaarverslagen van het Planbureau over I95I en I952 (L. VAN GEUNS, I953). Op 24 december I952 werd geconcludeerd dat de uitvoering van een stuwdam in de Surinamerivier, annex de bouw van een waterkrachtwerk met een vermogen van minstens roo.ooo kilowatt uit technisch oogpunt geen uitzonderlijke moeilijkheden zou opleveren, dat de locatie Sara de meest gunstige bouwplaats zou zijn en dat slechts de constructie van een aarden hoofddam economisch aanvaardbaar zou zijn (zie ook van GeUns, Schakels I953).

Een missie van de Internationale Bank voor Herstel en ONTWIKKELING onderzocht van 28 oktober tot 28 november I95I de economische situatie in Suriname en stelde in de Technische Bijlage No. 4 van haar rapport van 6 mei 1952 vast dat de bouw van een dam te Brokopondo tot de technische en economische mogelijkheden zou behoren; geadviseerd werd studies te verrichten met betrekking tot een betonnen dam, als alternatief van een aarden of stenen dam. Zie ook het Planbureau-ontwerp De grondslagen van een tienjaren plan voor Suriname (Het Brokopondoplan, p. I08-II3), juni I952.

De uitvoerige nota, gedateerd 2 I november I952, van de BILLITON MAATSCHAPPIJ kwam daarentegen, op grond van de door deze maatschappij ingestelde geologische en technisch-economische studies, tot weinig optimistische conclusies. Uitgebreide geologische waarnemingen zouden volgens de nota nog moeten worden verricht alvorens voldoende fundamentele kennis is verkregen omtrent tracé en bouwwijze van hoofd- en bijdammen. Voorshands werden de bouwkosten abnormaal hoog geschat, in verband met de grote lengte van de stuwdammen en de diepe verwering van het gesteente, en de kilowattuurprijs van een rendabele waterkrachtcentrale te hoog bevonden voor een aluminiumindustrie. Ook zou er generlei zekerheid zijn voor regelmatige afzet van het product van een Surinaams aluminiumbedrijf. De nota werd overigens van verschillende zijden bekritiseerd (zie vaN GEUNS' Nota van I7 maart 1953; Planbureau, april 1953, Beoordeling van het Billiton Maatschappij rapport). 
Intussen, op 2 oktober 1952, was reeds door de Surinaamse regering een overeenkomst gesloten met de SOCIÉTÉ ANONYME DES Grands Travaux DE MARSEILle (G.T.M.) voor het opstellen van een rapport omtrent de technische en economische aspecten van de bouw van een stuwdam annex waterkrachtwerk in de Suriname-rivier. Een en ander zou in samenwerking geschieden met het ingenieursbureau ANDRÉ COYNE \& JEAN BELliER, de CoMPAGNIE DE FIVES-LILle (C.F.L.), fabrikant van mechanische en electrische outillage, en ALFRED FalCONNIER, deskundige op het gebied van damgeologie. Deze eerste missie van G.T.M. c.a. rapporteerde reeds in december 1952 , zij het op nog onvoldoende topografische en geologische gegevens, in gunstige zin; voorkeur werd uitgesproken voor een geheel betonnen dam (zie ook Note complémentaire, januari 1953). Het Planbureau gaf over de G.T.M.-rapporten een beknopt overzicht in april 1953, en over kilowattuurprijsberekeningen op grond van NEDECO- en G.T.M.-gegevens een nota in oktober 1953 (zie over NEDECO hieronder).

Eysvoogel (1953) kwam, in tegenstelling tot G.T.M., tot de conclusie dat een aarden dam voorkeur zou verdienen.

Met schrijven van 8 juli 1953 van de Algemene Vertegenwoordiger van Suriname in Nederland werd het Nederlands Adviesbureau voor Ingenieurswerken in het Buitenland NEDECO, Den Haag, uitgenodigd de Surinaamse regering van advies te dienen inzake het vooronderzoek tot de bouw van een stuwdam in de Suriname-rivier met bijkomende werken en een op te stellen voorproject. Op grond van de bevindingen van de naar Suriname geżonden missie, de evaluatie van de reeds verkregen gegevens en de eerder over het project uitgebrachte adviezen en met inschakeling van verschillende experts op technisch, economisch en financieel gebied, bleek het NEDECO mogelijk reeds I oktober I953 een Advies inzake Combinatieplan Suriname Rivier (een Nederlandse én een Engelse versie) aan de regering uit te brengen, voorzien van 6 bijlagen. In dit advies zijn behalve een historisch overzicht en een uitvoerige beschouwing over het rapport van de Société des Grands Travaux de Marseille, het gewenste (aarden!) damtype, de economische aspecten, de invloed op de aluminiumindustrie in en buiten Suriname en de bauxietmijnbouw, o.a. in het te ontsluiten Nassau-gebergte, op gedegen wijze onder de loupe genomen. De hydrologische aspecten werden opnieuw bekeken; met de conclusies van RiNGma (1953) werd in het algemeen ak- koord gegaan. NEDECO's eindadvies behelsde een aanbeveling om onderhandelingen te voeren met een of meer geinteresseerde 
aluminium-industrieën over verder onderzoek en uitvoering van het project en een aanbeveling om de hydrologische waarnemingen, mede in het gebied van de Tapanahony en Lucie-rivier, voort te zetten. Het rapport is vrijwel geheel afgestemd op het aluminiumindustrie-aspect; slechts terloops zijn nevenvoordelen van het project bekeken, zoals betere afvoer van bos- en mijnbouwproducten, betere bevaarbaarheid van de Suriname-rivier, visvangst in het stuwmeer: "een zeer uitgebreid studieterrein ligt nog braak, waarover men niet te licht mag denken" (hoofdstuk V 2).

De Stichting Planbureau Suriname droeg in oktober I953 aanzienlijk bij aan de begripsvorming door het samenstellen van een Overzichtskaart van het toekomstige stuwmeer in de Suriname-rivier, schaal $I$ : Ioo.ooo, waarop - aan de hand van hoogtelijnen om de 50 meter en van de vermoedelijke situatie van de hoofddam bij Afobaka ('Sara') en hulpdammen ter weerszijden - de omtrek van het meer is geschetst. Deze omtrek heeft door de grotendeels vlak-komvormige topografie van het dal, met gering relief, een uitermate grillige vorm; talloze zeer kleine eilanden zouden bovendien in het meer komen te liggen. Opgemerkt wordt dat de op deze kaart gegeven topografie in feite die is van het kronendak van het bos.

Het NEDECO-rapport gaf aanleiding tot hernieuwd overleg tussen de Surinaamse regering en de Franse groep G.T.M.-C.F.L., aan wie op I5 januari I954 opdracht werd verleend voor de completering van het vooronderzoek en de opstelling van een definitief avant-project met kostenraming van het waterkrachtwerk, waarin zowel een betonnen als een aarden uitvoering van de dam zouden worden gecalculeerd. De regering behield zich in de overeenkomst het recht voor een concurrerende groep in te schakelen voor het maken van een bestek (zie o.m. Jaarverslag Planbureau over 1953 en 1954 ).

Op basis van genoemde opdracht zette de Franse groep zich in februari I954 opnieuw aan het werk, met inschakeling van de boorfirma Société SolÉTANCHE voor het doen van kernboringen in het hoofddamtracé; deze boringen werden medio juli voltooid. Het overige vooronderzoek geschiedde in nauwe samenwerking met het Planbureau, de Geologisch Mijnbouwkundige Dienst en het ook reeds eerder ingeschakelde LABORATORIUM VOOR GRONDMECHANICA te Delft, het laatste vooral met het oog op een advies over de mogelijkheid van constructie van een aarden dam. Het eindrapport van het Laboratorium verscheen in augustus I954.

Het Planbureau nam in februari I954 de terreinwerkzaamheden met betrekking tot het grondmechanisch onderzoek van de 
Delftse Laboratoriumdeskundige over, vervolgde de hydrologische waarnemingen en topografische opmetingen, welke alle aan de Franse groep en later ook aan Harza (zie hieronder) ter beschikking werden gesteld. De interpretatie van de hydrologische gegevens werd door Ir. RINGMA in Nederland verzorgd en vastgelegd in de Hydrologische Nota's Nos. 7-9 (I954) en Io (I957). In 1955 werden in het stroomgebied van de Tapanahony opmetingen verricht met het oog op het eventueel aldaar scheppen van een additioneel stuwmeer ten behoeve van het krachtwerk in de Surinamerivier.

Gebruik makende van het recht, in de overeenkomst met de Franse groep bedongen, om een concurrerende groep in te schakelen, gaf het Planbureau namens de Surinaamse Regering op ro juli I954 opdracht aan de Harza EngineEring CoMPANY, Chicago, om een technisch rapport te maken over de constructie van de meest in aanmerking komende dam en bijbehorende hydro-electrische werken. Harza bracht het eerste rapport (Phase I) uit op I5 november 1954. Nadat, reeds vóór die datum, uit de voorbereidende studies de technische en economische uitvoerbaarheid gebleken was, sloot het Planbureau namens de Regering op 2 oktober I954 opnieuw een overeenkomst met Harza voor Phase II en wel voor het vervaardigen van bestekken en tekeningen.

Harza's tweede rapport en het rapport van de Franse groep werden in maart I955 aan de Regering overgelegd, met gegevens over de te verwachten kosten van een aarden hoofddam van 50 meter hoogte en I56o meter lengte, alsmede van een waterkrachtcentrale met een continu gemiddeld vermogen van II 5.000 kilowatt. Beide rapporten stelden vast dat het project technisch uitvoerbaar zou zijn. Dit was reden voor de Regering opnieuw besprekingen te gaan voeren met eventuele gegadigden voor de afname van de op te wekken energie (zie o.a. Jaarverslag Planbureau over 1954 en 1955 ).

Door de toenmalige directeur van het Planbureau, Drs. Ir. M. H. EKKER (in functie sedert I5 december 1952) werd in maart-april I954 een waardevolle uiteenzetting gegeven over het Brokopondoplan, "stellig het grootste en meest gedurfde project dat ooit voor Suriname werd ontworpen, een project dat, indien het tot uitvoering komt, het gehele economische leven van ons land op een ander niveau zal kunnen brengen." Het plan - aldus EKKER voorziet bij de geprojecteerde stuwhoogte van 42 meter (stuwdam-hoogte 50 meter boven de rivierbodem) de jaarlijkse levering 
door de waterkrachtcentrale van rond I milliard kilowattuur energie, door voeding uit een I350 vierkante kilometer groot stuwmeer ( $\mathrm{r} \%$ van de oppervlakte van Suriname) met een waterinhoud van 18 milliard kubieke meter. De bouwkosten van hoofden hulpdammen en centrale zouden een uitgave vergen van rond S $f$ roo millioen. Ongeveer $95 \%$ van de op te wekken energie zou bestemd zijn voor de jaarlijkse productie van 40.000 ton aluminium via 80.000 ton aluinaarde uit 160.000 ton bauxiet, d.i. ongeveer I/20 deel van de toenmalige bauxietproductie van Suriname. EKKER wees op het nadeel dat een zeer groot gebied verloren gaat voor bosexploitatie en mijnbouw (al bleek niet dat zich hier waardevolle ertsvoorkomens bevinden) én voor bewoning en levensonderhoud van de Bosnegerbevolking. Hij vestigde ook de aandacht op de voordelen van gemakkelijke toegang van het toekomstige oevergebied en op de regularisering van het rivierdebiet (van gemiddeld ca. 400 kubieke meter per seconde), tot dan variërend bij Brokopondo van 20 in de droge tijd tot boven 2000 in de regentijd; die regularisering is uiteraard essentieel voor een constante energievoorziening.

H. Teunissen (die Ir. EkKer op 30 september I954 opvolgde als directeur van het Planbureau) gaf in oktober I955 een beschouwing die het artikel van EKKER (I954) ten dele herhaalde en ook aanvulde. Volgens zijn mededeling was het de bedoeling dat de bouw en exploitatie van de dammen en de bijbehorende hydroelectrische werken door het Land of een Landsbedrijf zouden geschieden (met behulp van een lening) en dat de bouw en exploitatie van het aluminium-reductiebedrijf door een particuliere investeerder zouden worden gefinancierd, waarbij de energie van het Land zou worden gekocht; de bauxiet van het Nassaugebergte, geschat op maximaal I5 millioen ton - voldoende voor een jaarlijkse productie van 40.000 ton aluminium gedurende 95 jaar zou gereserveerd moeten worden voor de maatschappij die het reductiebedrijf bouwt. Volgens intussen ingestelde globale onderzoekingen zou door koppeling van een Tapanahony-stuwmeer (afgedamd bij Affivisiti) aan het Brokopondomeer drie en een half keer zoveel energie kunnen worden opgewekt als door het Brokopondomeer alleen, zodat I40.00o ton aluminium per jaar zou kunnen worden vervaardigd. TEUNISSEN legde mede de nadruk op de vergroting van de werkgelegenheid (wat de bouw van de dam en de centrale betreft overigens van tijdelijke aard) en de verbreding van de industriële basis.

Volgens van GeUNS (I955) zou een stuwmeer worden gevormd 
met, bij het hoogste peil van $45 \mathrm{~m}$ bij de dam, een oppervlakte van rond 1500 vierkante kilometer. Afleiding van het Tapanahony-water naar het Brokopondomeer en de bouw van enkele waterkrachtcentrales in de Sarakreek zou volgens hem een verhoging van de electrische energiehoeveelheid van I milliard kilowattuur met wellicht 2 milliard, dus tot totaal 3 milliard, mogelijk maken.

Het spreekt vanzelf dat in Suriname veel publiciteit is gegeven aan het Brokopondo-plan. De voorlichting aan kranten en tijdschriften werd er o.a. verzorgd door het BROKOPONDOBUREAU. Het werd bij Resolutie van 3I juli 1957 door de Regering ingesteld op I augustus I957 (door afsplitsing van het Planbureau) en wel voor het maken van een ontwikkelingsprogramma voor het gehele Brokopondogebied; bij Resolutie van I7 oktober I958 werd de taak van het bureau gericht op het uitvoeren van de projecten welke ingevolge de (hieronder te bespreken) Brokopondo-overeenkomst door Suriname dienden te worden verwezenlijkt. Die voorlichting was steeds zeer optimistisch van toon, maar soms eenzijdig en onjuist.

Om slechts één enkel voorbeeld te noemen: In een ongedateerde maar denkelijk ongeveer $195^{8}$ uitgegeven, in simpele taal gestelde folder van het Brokopondobureau, onder de naam Licht en kracht uit de oerwouden van Suriname, worden de voordelen van het plan breed en tendentieus uitgemeten. Gesuggereerd wordt o.a. dat vóór de inundatie het waardevolle hout gekapt zou kunnen worden; dat het niet zo erg is dat een aanta dorpen van de boslandbewoners verdwijnen omdat daardoor die menser een kans op betere woonplaatsen en een beter bestaan krijgen en niet langer afgezonderd in de bossen behoeven te blijven ("een stuk wildernis wordt van ze weggenomen en er komt een eind aan hun nutteloze afzondering"; " 'ook voor hen is het Brokopondoplan dus van heel veel waarde"); dat de bosrijke oevers van het meer en de eilandjes daarin voor vermaak en toerisme kunnen dienen; dat het meer een uitstekende kweekplaats voor vis is, "voor misschien ongelooflijke hoeveelheden daarvan".

De Raad van Ministers besloot op 3 augustus I957 een Commissie in te stellen aan welke de beraadslagingen over en de beslissingen inzake het Brokopondo-plan werden toevertrouwd, bestaande uit de Minister-President, de Minister van Financiën, de Minister van Economische Zaken en de Minister van Openbare Werken en Verkeer, en als Sekretaris Ir. R. ZonNeveld van het Brokopondobureau (Resolutie van 7 augustus I957). Op II december 1958 bepaalde de Raad van Ministers dat genoemde Commissie zal worden aangeduid als de BROKOPONDORAAD (Resolutie van 9 januari 1959). Opgemerkt wordt overigens dat reeds veel eerder in, 
augustus I953, bij Resolutie een 'Brokopondo-Raad' was ingesteld voor het dienen van advies, onder voorzitterschap van de directeur van het Planbureau; de naam daarvan is later gewijzigd in Studieraad Brokopondo-Plan (zie hoofdstuk 2. Natuurwetenschappelijke, medische en sociologische aspecten).

Ook in Nederland trok uiteraard het stuwmeerplan belangstelling, in de pers en in de Staten-Generaal. Wat de laatste betreft wordt 0. .a. gewezen op het Voorlopig Verslag van 18 november I955 over de Rijksbegroting 1956, Hoofdstuk XIII, Overzeese Rijksdelen, en de Memorie van Antwoord van I december 1955 van de Minister van Overzeese Rijksdelen; alsmede op het verslag van de delegatie uit de Staten-Generaal over het bezoek aan Suriname in maart 1957 (3I oktober I957). Desalniettemin bleven onderhandelingen tussen de Surinaamse en Nederlandse Regeringen over een langlopend (40 jaren) Nederlands crediet van S $f$ I 20 millioen, te bestemmen voor de bouw van de dam en de waterkrachtcentrale, met een rente van maximaal $4 \frac{3}{4} \%$, zonder resultaat. Evenmin gelukte het de Surinaamse Regering zulk een lening in de U.S.A. te sluiten.

Gelukkig voor de stuwdampropagandisten werd door de G.T.M.- en Harza-rapporten van maart 1955 (opnieuw) de interesse gewekt van de Aluminum Company of America (Alcoa), welker dochteronderneming de Surinaamsche Bauxite Maatschappij immers nauw betrokken was met de plannen. De in I 956 begonnen besprekingen en onderhandelingen tussen Alcoa en de Surinaamse Regering vonden hun eerste resultaat in de op 4 februari I957 geparafeerde 'letter of intent', waarin Alcoa zich in principe bereid verklaarde in Suriname een aluminiumsmelterij te bouwen indien de Surinaamse Regering de stuwdam en de hydro-electrische centrale zou financieren en voldoende electrische stroom daarmee zou kunnen leveren. De 'letter of intent' werd op I maart door de Staten van Suriname bekrachtigd. Nadat in de loop van I957 was gebleken dat financiering door de Surinaamse Regering op grote moeilijkheden stuitte door het niet kunnen afsluiten van een lening, bleek Alcoa bereid een veel grotere financiële last op zich te nemen dan aanvankelijk bedoeld was. Het was hiervoor gewenst de Surinaamsche Bauxite Maatschappij om te zetten in een nieuwe vennootschap die zowel de bauxiet zou ontginnen en de hydro-electrische energie produceren voor aluminiumfabricage. Zo ontstond in december 1957 de nieuwe Amerikaanse dochtermaatschappij van Alcoa, genaamd Suriname Aluminum Company (Suralco), met zetel in Wilmington, Delaware. De 
Surinaamse Regering sloot kort daarna, op 27 januari $195^{8}$, de Brokopondo-overeenkomst met Suralco, na bij Landsverordening van 25 januari $195^{8}$ machtiging te hebben gekregen "tot het aangaan van overeenkomsten met de Suralco inzake de ontwikkeling van het waterkrachtpotentieel van Suriname". Deze overeenkomst, en alles wat annex is, is uitvoerig vastgelegd in de publikatie Brokopondo. Gemeenschappelijke onderneming Suriname-Surah co (in 1959 in druk verschenen).

De Brokopondo-overeenkomst, een 'joint venture', is geldig voor 75 jaar. $Z_{i j}$ verplichtte Suralco op haar kosten de stuwdam, het waterkrachtwerk met bijkomende werken en de hoogspanningsleiding Afobaka-Paranam te bouwen, te onderhouden en te exploiteren. Van de jaarlijks op te wekken energie van ca. I milliard kilowattuur werd 80 millioen voor het land Suriname bestemd en de overige energie voor de aluminiumproductie van Suralco. De dambouw bij Afobaka zou vóór het einde van I96o een aanvang moeten nemen. $\mathrm{Na}$ de periode van 75 jaar dient het gehele waterkrachtwerk gratis aan Suriname te worden overgedragen. Suralco nam voorts op zich een aluminiumsmelterij te bouwen bij Paranam, op te leveren tegen de tijd dat de eerste electrische energie vrijkomt. Bovendien verplichtte Suralco zich om in een later stadium - binnen I6 jaar na 27 januari 1958 ò binnen I2 jaar na de volledige inbedrijfstelling van de smelterij - een aluinaardefabriek te bouwen voor het thermochemisch verwerken van bauxiet tot aluinaarde (aluminiumoxide, alumina, $\mathrm{Al}_{2} \mathrm{O}_{3}$ ), zodat dan binnen Suriname uit de ruwe bauxiet, via aluinaarde, de aluminium kan worden vervaardigd. Zolang de aluinaardefabriek niet gereed zou zijn, zou Suralco aluinaarde uit het buitenland importeren voor het smelten tot aluminium. Een gedeelte van het in Suriname te verkrijgen metaal zal worden bestemd voor industriële verwerking binnen het land zelf, in de Nederlandse Antillen en in Nederland.

De deelname van Suriname in de 'joint venture' bestaat uit het ter beschikking stellen van land en water, de vooronderzoekingen, de bebakening in het stuwmeer, de verplaatsing van de Bosnegerbevolking uit het te inunderen gebied, de voorzieningen op het gebied van hygiëne en assainering, en de bouw van het deel van de hoogspanningsleiding dat bestemd is de electriciteit van Paranam naar Paramaribo over te brengen.

Voorts werd overeengekomen dat Suralco op haar kosten de weg Paranam-Afobaka zou aanleggen en onderhouden, maar dat 
Suriname voor die weg tenminste $\mathrm{S} f 3.000 .000$ en maximaal Sf 4.000.000 aan Suralco zal betalen zodra het waterkrachtwerk gereed is voor volledige en normale exploitatie, d.w.z. wanneer het water in het stuwmeer is gestegen tot op of boven 43 meter boven Surinaams peil en wanneer alle onontbeerlijke delen van het werk bedrijfsklaar zijn; die weg zou van dat tijdstip af als openbare weg ten laste van het Land moeten worden onderhouden. Suralco verplichtte zich voorts om de Regering voor de betaling van de weg en ook voor andere uit Suriname's aandeel voortvloeiende verplichtingen een renteloze lening te verstrekken van maximaal S f I2.000.000; terugbetaling zou moeten geschieden in 20 gelijke jaarlijkse termijnen, waarvan de eerste vervalt in het vierde kalenderjaar van volledige en normale exploitatie van het waterkrachtwerk.

De Brokopondo-overeenkomst voorziet eveneens in mogelijke uitbreiding van het stuwmeer door kunstmatige inundatie van delen van het Tapanahony-stroomgebied.

De overeenkomst is voor Suralco mede aantrekkelijk omdat die gebonden is aan een verlenging met 45 jaar van de bestaande bauxietconcessies, aan uitbreiding van het bauxietconcessieareaal en aan een gunstige belastingregeling in de U.S.A. Wat de bauxietontginning betreft, kreeg Suralco een exploratie-concessie voor een oppervlakte van 2 millioen hectare, begrensd door de Atlantische Oceaan, de Suriname-rivier, de 4de breedtegraad en de Marowijne. Na Io jaar zou dit exploratie-terrein aanzienlijk worden ingekrompen en na 20 jaar zou voor maximaal 20.000 hectare een exploitatie-concessie kunnen worden verkregen (de huidige concessies bij Moengo en Paranam beslaan ongeveer 40.000 hectare). Zou Suralco op meer dan die 20.000 hectare willen ontginnen, dan kan zij meedingen met eventuele andere gegadigden. 1

Voor de (Amerikaanse) Suralco is belastingtechnisch voordelig de in de U.S.A. bestaande regeling van de Western Hemisphere Trade Corporation Act, die aan Amerikaanse ondernemingen die op grote schaal buiten de U.S.A. op het westelijk halfrond investeren, de zg. Western Hemisphere

1 Vermeldenswaard is dat medio 1969 door Suralco werd begonnen met de aanleg van een ontsluitingsweg van de Locuskreek aan het stuwmeer naar de voet van het nabije Nassaugebergte, gelegen in het nieuwe concessiegebied, ten behoeve van booronderzoek van de bauxietafzettingen aldaar. Op grond van het in 1953 beëindigde onderzoek door de Geologisch Mijnbouwkundige Dienst werd - zoals vermeld - indertijd de hoeveelheid bauxiet in het Nassaugebergte op 15 millioen ton geschat. 
Trade Corporations, aanzienlijke belastingvermindering verleent. Hun winst wordt voor slechts $38 \%$ belast tegenover de normale $52 \%$, terwijl voor mijnbedrijven nog aftrekposten zijn toegestaan, waardoor voor hen de belasting $30 \%$ van de winst bedraagt. De U.S.A. beoogt hiermee een indirecte bevordering van investeringshulp voor de ontwikkelingslanden, die even goed als, zo niet beter werkt dan, een rechtstreekse gift. Bovendien werd in Suriname vrijstelling van de overwinstbelasting bedongen, waardoor slechts de gewone inkomstenbelasting van $30 \%$ verschuldigd is.

Uit het bovenstaande is duidelijk dat de financiering van het project vrijwel geheel met buitenlands kapitaal is geschied en dat er in slechts geringe mate een beroep op de schatkist behoefde te worden gedaan. Ondanks deze voor Suriname zeer voordelige transactie, heeft de Regering meer dan eens gewaarschuwd tegen al te optimistische verwachtingen voor de welvaart. ${ }^{1}$

In verband met de door het Brokopondo-project sterk toegenomen werkzaamheden in het stroomgebied van de Surinamerivier werd op I januari I959 door de Regering een nieuw district gecreëerd, het Brokopondo-district, door gedeelten van de districten Saramacca, Suriname en Marowijne tezamen te voegen. Drs. J. Michels werd benoemd tot Districtscommissaris.

Voorts liet de Regering zich inlichten "inzake de vermoedelijke expansieve invloed op de Surinaamse volkshuishouding van de uitvoering van het Brokopondoplan en andere tegelijk daarmede te entameren ontwikkelingsprojecten, tevens ... over het in verband hiermede te volgen Regeringsbeleid ter handhaving van de interne en externe stabiliteit en verdere voorwaarden voor een gezonde economische bloei van Suriname". Daartoe brachten in april 1959 Prof. Mr. P. LiefTinck, lid van de raad van bestuur van het InTERnationale Monetaire Fonds en van de WereldBANK, en Prof. Dr. C. Goedhart, hoogleraar aan de Universiteit van Amsterdam, een bezoek aan Suriname. In oktober van dat

1 Door de Société Anonyme des Grands Travaux de Marseille werd na de afsluiting van de Brokopondo-overeenkomst tussen de Surinaamse Regering en Suralco een schadeloosstelling van Suriname geëist ten bedrage van N $f$ I 2 millioen. Destijds (8 januari I954) was namelijk overeengekomen dat G.T.M. het avant-projet van de stuwdam zou maken en voor eventuele dambouw prioriteit zou krijgen als bouwer. Door de overeenkomst met Suralco, waarbij Suriname afzag van het zelf financieren van de bouw, voelde G.T.M. zich derhalve benadeeld. $Z$ ie over het verloop van deze kwestie o.a. Weekberichten Bedrijfscontact Nederland-Suriname 1960-1962; na oktober 1962 is hierover niet meer gepubliceerd. Over de nadien door beide partijen getroffen onderlinge schikking zijn geen bijzonderheden bekend gemaakt. 
jaar kwam hun rapport beschikbaar (Stichting Planbureau Suriname, Jaarverslag I959; december I960).

In een voordracht van Ir. H. MEYER, directeur-beheerder van de Suralco, gehouden voor het Koninklijk Instituut van Ingenieurs, 's-Gravenhage, op 22 april I96o (MEYER I960) heeft deze een toelichting gegeven op het door Suralco in uitvoering genomen Brokopondoplan. Volgens hem zou de jaarlijkse energieproductie wel rogo millioen kilowattuur kunnen worden. Suralco produceerde in de periode kort vóór I960 $2 \frac{1}{2}$ à $2 \frac{3}{4}$ millioen metrieke ton bauxiet per jaar, verscheept naar de U.S.A. Het zou de bedoeling zijn de verscheping naar de U.S.A. op ongeveer hetzelfde peil te houden en jaarlijks een extra hoeveelheid bauxiet van ruim 200.000 ton te produceren, om daarvan thermochemisch ca. I00.00o ton aluinaarde te maken en die door electrolyse om te zetten in ca. 50.000 ton aluminium, waarbij voor de bereiding van I kilogram aluminium ruim 20 kilowattuur benodigd is. De in Paranam te bouwen aluinaarde-fabriek zal echter meer dan roo.000 ton aluinaarde per jaar produceren en het surplus zal naar smelterijen in de U.S.A. worden geëxporteerd.

Suralco's Construction Division begon in juli I959 met de aanleg van de weg Paranam-Afobaka; deze werd op 26 augustus I 960 officieel in gebruik genomen ('De Paranam-Affobakka weg grandioos geopend', Bauxco Nieuws, september I96o, p. 3-9). Sedertdien werden de werkzaamheden sterk geconcentreerd bij de stuwdamlocatie Afobaka. De vorderingen van de bouw van het Brokopondo-project zijn regelmatig gerapporteerd in De Ingenieur ('s-Gravenhage, I960, Nr. 40, p. B. I27; I96r, Nr. 48, p. B. 22I, en volgende), Bauxco Nieuws (Paramaribo, Maandblad voor geëmployeerden van de Suriname Aluminum Company, 1959-1965), Surinaams Nieures (Wekelijkse uitgave van het Kabinet van de Gevolmachtigde Minister van Suriname, 's-Gravenhage), en de Weekberichten van de Vereniging Bedrijfscontact Nederland-Surina$m e$ ('s-Gravenhage, tevens publikatie van de Vereniging Surinaams Bedrijfsleven te Paramaribo). Een uitstekend, vooral technisch georiënteerd overzicht biedt het artikel van HILLEN \& ACHTERHOF in het Polytechnisch Tijdschrift (1965).

Tijdens de bouw van het kunstwerk werden door Suralco's Public Relations afdeling in een geillustreerde folder getiteld $\mathrm{Het}$ Brokopondo Project (september I962) technische gegevens verstrekt, waarvan enkele hieronder zijn overgenomen (zie ook $\mathrm{Be}$ knopte gegevens Suralco, I969). Het stroomgebied boven de dam beslaat $12.200 \mathrm{~km}^{2}$. De oppervlakte van het geheel gevulde stuw- 
meer, met een waterstand bij normale bedrijfsvoering van 50 meter, is berekend op $1560 \mathrm{~km}^{2}$, waarbij de nuttige waterberging I2.400 millioen kubieke meter zou zijn. De gemiddelde jaarlijkse afvoer bedraagt 390 kubieke meter per seconde en de gemiddelde valhoogte is genomen op 4I $\frac{1}{2}$ meter; bij geheel gevuld meer is de valhoogte iets groter, namelijk 43 meter. De lengte van de hoofddam is I 913 meter, de hoogte 54 meter. Er zijn I6 hulpdammen van totaal 6400 meter lengte. Het krachtwerk bevat 6 turbines met een totaal geinstalleerd vermogen van I80.000 kilowatt en een op te wekken energie van meer dan I milliard kilowattuur per jaar, met $92 \%$ waarvan Suralco een jaarproductie van maximaal 60.000 ton ruw aluminium kan bereiken (de productie in 1968 bedroeg 79I millioen kilowattuur).

Van de 6 turbines zal er steeds één in reserve worden gehouden. Vermeldenswaard is nog dat, gezien het hoogteverschil van ongeveer 40 meter boven en beneden de dam, is afgezien van het construeren van een scheepvaartsluis. Voor een verbetering van de afstroming beneden de dam werden in het na de afsluiting op I februari r 964 (zie hieronder) tijdelijk drooggevallen gedeelte van de rivierbedding de rotsen van de stroomversnellingen door Suralco's dynamietploegen opgeruimd.

Op I februari 1964 werd de laatste van de drie tijdelijke omleidtunnels onderin de overlaat gesloten, waarmee de afsluiting van de Suriname-rivier een feit werd en het stuwmeer zich begon te vormen.

Ondertussen was op I januari I959 onder leiding van Drs. J. Michels een aanvang gemaakt met de in 1964 te voltooien transmigratie van de boslandbevolking uit het te inunderen gebied. Voor de meer dan 5.00o Bosnegers van 28 Saramaccaanse en 6 Aucaanse dorpen werden I3 nieuwe dorpen aangelegd bovenstrooms van het stuwmeer, ro benedenstrooms en één aan de spoorweg bij Brownsweg. De twee grootste transmigratiedorpen zijn Brownsweg (ca. I500 inwoners) en Nieuw-Ganzee bij de Klaaskreek, beneden de dam (ca. I200). In het Weekblad Revue $\alpha$ (Nr. 39 van 25 september I965) is op aardige wijze beschreven hoe Districtscommissaris MrCHELs te werk ging bij het voorbereiden van de Bosnegers op deze gedwongen verhuizing.

In september 1963 werd door Suralco begonnen met de bouw van de aluina ardefabriek (dus veel eerder dan in 1958 de bedoeling was) en de aluminium smelter, te Paranam. Na een eerste proefdraaiing van het waterkrachtwerk te Afobaka, op 29 juli 
I965, werden in oktober I965 enkele turbines definitief in werking gesteld, kwam de eerste electrische energie vrij en kwamen de eerste twee productie-eenheden van de aluinaardefabriek en de smelter in bedrijf. Op 9 oktober 1965 werd het nieuwe geintegreerde aluminiumbedrijf te Paranam officieel in gebruik gesteld door Hare Majesteit Koningin Juliana.

In $1966 \mathrm{kwamen}$ een derde en vierde productie-eenheid van de aluinaardefabriek in bedrijf. Van het totaal van Suralco's productievermogen van 800.000 ton aluinaarde per jaar werd ongeveer I20.000 ton bestemd voor het zelf produceren van ca. 60.000 ton aluminium; I30.000 ton aluinaarde, te maken uit 260.000 ton bauxiet van de Billiton Maatschappij, werd bestemd voor deze Maatschappij - die het product naar haar Nederlandse aluminium smelter uitvoert - en 550.000 ton voor export door Suralco, hetzij voor aluminiumfabricage elders, hetzij voor andere eindproducten (Dit is de Suralco, I966). Begin 1969 werd een vijfde en voorlopig laatste productie-eenheid voor aluinaarde te Paranam in gebruik genomen; de totale capaciteit van de aluinaardefabriek van Suralco is daardoor gestegen tot I millioen ton per jaar (Beknopte gegevens Suralco, I969). In I969 heeft Suralco 2.I77.503 metrieke ton bauxiet, 509.708 idem aluinaarde en 53.I23 idem aluminium uit Suriname geëxporteerd. De aluminiumsmelter had in 1969 een productie van ca. $70 \%$ van het vermogen, het maximum dat met de beschikbare waterkrachtenergie kon worden geleverd. Het waterkrachtstation produceerde in I969 ca. 84I millioen kilowattuur, d.w.z. bijna $85 \%$ van de verwachte hoeveelheid.

Eind I966, nadat in april de derde turbine in bedrijf was gesteld, kon - door de geringe stijging van het stuwmeerpeil - slechts de helft van het verwachte electrische vermogen geproduceerd worden.

Naar aanleiding van de geringe stijging van het peil werd door de Nederlandse Vice-Minister-President Mr. B. W. Biesheuvel op 27 april 1966 in de Eerste Kamer van de Staten-Generaal, bij de behandeling van het wetsontwerp tot vaststelling van hoofdstuk IV der rijksbegroting voor het dienstjaar I966, een kort overzicht van de situatie gegeven en meegedeeld dat Suralco "vertrouwen in het welslagen van deze onderneming" behoudt.

Als antwoord op een op 5 januari 1967 in de Tweede Kamer gestelde vraag van het lid VAN DER SLUIS (A.R.P.) deelde Minister BIESHEUVEL op I I januari mee dat volgens deskundigen niet gevreesd behoefde te worden voor teruglopen van de energievoorziening door onvoldoende waterstand.

In antwoord op het eindverslag van de commissie van rapporteurs voor zaken rakende Suriname en de Nederlandse Antillen omtrent het ontwerp van wet tot vaststelling van hoofdstuk IV voor het dienstjaar 1967 , werd 
door Minister BIESHEUVEL een nota ingezonden op 8 maart 1967, waarin opnieuw het probleem van de stuwmeervulling werd besproken en waarin enkele factoren werden genoemd die daarbij een rol zouden kunnen spelen. In een schrijven van ro april 1967 heeft de Natuurwetenschappelijke Studiekring voor Suriname en de Nederlandse Antillen het Kabinet van de Vice-Minister-President gewezen op de niet geheel juiste formulering van sommige dezer factoren.

In juli 1967 heeft Suralco als aanvulling van het vermogen van haar aluminiumsmelter - die ook toen nog slechts op halve kracht kon werken door te geringe watervulling van het stuwmeer en als bedrijfsonderdeel niet rendabel was - en tevens voor de productieeenheden van de aluinaardefabriek te Paranam een $47 \frac{1}{2}$ megawatt stoomturbinegenerator, gevoed met dieselolie, in bedrijf genomen; hierdoor kon tijdelijk één van de drie turbines te Afobaka worden stilgelegd. In I 969 produceerde de stoomcentrale bijna 375 millioen kilowattuur.

Op 2I augustus 1967 werd echter het peil van $24 \mathrm{I}, 08$ voet (gelijkgesteld met 43 meter boven Surinaams peil) bereikt. Volgens de Brokopondo-overeenkomst Artikel I I (c) is het waterkrachtwerk "gereed voor volledige en normale exploitatie, wanneer het water in het stuwmeerbekken zal zijn gestegen tot op of boven 43 meter boven Surinaams peil". Zo brak het moment aan waarop de Surinaamse Regering de Paranam-Afobaka weg en het onderhoud daarvan moest overnemen en waarop de eerste termijn inging van de terugbetaling in twintig termijnen van de renteloze lening van $\mathrm{S} f \mathrm{I} 2$ millioen.

Ten aanzien van de cijfers $24 \mathrm{I}, 08$ voet en 43 meter moet een correctie aangebracht worden. Bij het begin van de werkzaamheden in Afobaka waren daar de nauwkeurige hoogten ten opzichte van het Nieuw Surinaams Peil (NSP) nog niet bekend. Een fictief zeeniveau werd aangenomen, genoemd Sarapeil, en alle waterpeilmetingen in voet (H.E.D. = Hydroelectric Datum) werden op basis daarvan vastgesteld, na optelling van roo voet om niet met negatieve getallen te behoeven te werken. Door latere metingen werd het Sarapeil 5,908 voet $=1,8$ meter lager bevonden dan NSP.

Toen op 2 I augustus $196724 \mathrm{I}, 08$ voet werd gemeten, ging het om 24I,08 minus $100=14 \mathrm{I}, 08$ voet H.E.D. overeenkomende met 43 meter, d.w.z. 43 meter boven Sarapeil. Aangezien Sarapeil I, 8 meter lager blijkt te liggen dan NSP, was het waterpeil op genoemde datum in feite slechts $43-1,8=4 I, 2$ meter boven NSP.

Zie overigens ook het artikel 'Peilen in Suriname' in Bauxco Nieuws (augustus 1960).

Op genoemde datum van 2I augustus 1967 draaiden twee van de zes turbines (waarvan één steeds in reserve wordt gehouden) op $\frac{2}{3}$ van hun capaciteit. Om alle 5 turbines in bedrijf te krijgen en de 
maximum-productie van I milliard kilowattuur te bereiken is een peil van 253 voet nodig. (In de eerste helft van oktober I969 draaiden bij een peil van iets minder dan 253 voet vier van de zes turbines; in de tweede helft van mei I 970 eveneens vier bij een peil van 248 voet).

In het Vijfjarenplan $1967 \mathrm{t} / \mathrm{m}$ I97I zijn posten opgenomen voor verbeterings- en onderhoudskosten van de weg Paranam-Afobaka.

Nadat een begin van uitvoering was gemaakt met de benutting van de Suriname-rivier voor de productie van waterkracht werd overgegaan tot verdere inventarisatie van Suriname's waterkrachtpotentieel. In I959 werd door de Regering aan het Brokopondobureau opdracht verstrekt om in samenwerking met Harza Engineering Company, Chicago, dit potentieel te evalueren. In Harza's Appraisal Survey van I september I959 werd rapport uitgebracht.

In verband met het belang dat werd gehecht aan onderzoek en benutting van het waterkrachtpotentieel werd met ingang van I januari I962 (bij Resolutie van Io januari I962) de taak van het Brokopondobureau verruimd en de naam gewijzigd in BUREAU VOOR WATERKRACHTWERKEN.

Over de eventueel voor het Brokopondo-stuwmeer van belang zijnde stroomgebieden van de Saramacca en Tapanahony kan het volgende vermeld worden. In I963 werd door Ir. F. BREEVELD en Ir. R. ZONNEVELD een hydrologisch rapport over de Saramaccarivier samengesteld. Ir. W. J. van Blommestein, die eind mei I964 in Suriname terugkeerde, bracht in september van dat jaar een voorlopig advies uit over een afdamming en opstuwing van de Boven-Saramacca, met het doel het water daarvan naar het Brokopondomeer te leiden en een vergroting van de capaciteit van de Afobaka-centrale te verkrijgen van 5.000 kilowattuur. ${ }^{1}$ Ir. F. BREEVELD gaf op 5 mei 1964 een uitvoerige uiteenzetting over het Tapanahony-stuwmeerproject, waarover door de Regering en Suralco reeds besprekingen waren begonnen in verband met de vergroting van het debiet van het Brokopondomeer, in het kader van de Brokopondo-overeenkomst (Surinaams Nieures, 2 I maart I964).

1 De Raad van Ministers besloot op 20 oktober 1964 om, gelet op de verdiensten van Ir. vaN BLOMMESTEIN voor het Brokopondo-project, het zg. Brokopondo-meer bij Landsbesluit naar hem te noemen: Prof. Dr. Ir. W. J. van Blommestein stuwmeer. 
Uitvoeriger gegevens over het waterkrachtpotentieel van Saramacca, Tapanahony en de andere grote Surinaamse rivieren zijn bijeengebracht in deel 2 van het Nationaal Ontwikkelingsplan Suriname (Stichting Planbureau Suriname, 1965) - waarin ook een goed overzicht wordt gegeven van plannen en projecten voor de bevolking van het district Brokopondo - alsmede in het Memorandum voor de Regeringsperiode 1967-I97I (1967; hoofdstuk III, Waterkracht). De in I968 samengestelde niet-officiële overzichtskaarten van het Bureau voor Waterkrachtwerken voor geheel Suriname (schaal I : 500.000), van het Kabalebo-project ( $\mathrm{I}: 200.000$ ) en van West Suriname's irrigatieplan ( $\mathrm{I}: 250.000)$ zijn zeer bruikbaar voor het verkrijgen van een indruk van de plannen. ${ }^{1}$

\section{NATUURWETENSCHAPPELIJKE, MEDISCHE EN SOCIOLOGISCHE ASPECTEN}

In de bovenstaande historische schets zijn in hoofdzaak slechts de technische en economische aspecten van het Brokopondo-waterkrachtwerk en stuwmeer ter sprake gekomen. In vervolg daarop wordt thans beschreven hoe van niet-technische en niet-economische zijde een inbreng is geleverd in het project.

Nadat van Blommestein zijn technische combinatie-plan voor de Suriname-rivier in augustus I950 openbaar had gemaakt, vonden daarover besprekingen plaats in het bestuur van de NATUURWETENSCHAPPELIJKe STUdiekring voor SuRINAME EN DE NEDERLANDSE ANTILLEN. Na de vergadering van 7 april 1952 werd een nota ontworpen, waarin de consequenties van het plan voor de bodem, hydrologie, flora, fauna en volksgezondheid in het betreffende gebied uiteengezet werden. Met aanbieding van de nota

1 Op de volgende door het Centraal Bureau Luchtka(a)rtering uitgegeven kaarten zijn de contouren van het Brokopondomeer in maximale uitbreiding ingetekend:

Schaal I : 100.000; hoogtelijnen interval $=25 \mathrm{~m}$ tot $100 \mathrm{~m}$ hoogte, daarboven $50 \mathrm{~m}$. Blad 30, 31, 32, 39 (re druk 196I), 38 (2e druk r963). CBL deelde op 12 november 1965 mee dat de maximale hoogte van het waterniveau in het stuwmeer zal worden gehouden op ca. $48,50 \mathrm{~m}$ N.S.P., terwijl op de kaart als grens van het meer de $50 \mathrm{~m}$ hoogtelijn is aangegeven. Het voor deze kaart gebezigde referentievlak is gelegen op- $1.50 \mathrm{~m}$ N.S.P.

Schaal I : 500.000 ; hoogtelijnen interval $=250 \mathrm{~m}$. Blad I, II (3e druk I968), III, IV (2e druk I968), met Brokopondomeer en overige in Suriname geprojecteerde stuwmeren. 
aan de Surinaamse Regering werd echter gewacht tot na de door de International Union for the Protection of Nature (I.U.P.N.) in Caracas, Venezuela, te houden conferentie in september I952, van welker programma een der thema's aan de ecologische consequenties van hydro-electrische werken zou worden gewijd.

De United Nations Scientific Conference on the Conservation and Utilization of Resources (UNSCCUR), gehouden in I949 in Lake Success, N.Y., U.S.A., en de genoemde Technical Meeting of I.U.P.N. in I952, Caracas, besteedden veel aandacht aan de problemen verband houdende met toenemende dienstbaarmaking van rivieren voor energievoorziening, irrigatie, scheepvaart, visserij en recreatie. In een der resoluties van de Caracas-conferentie is aangedrongen op grote voorzichtigheid bij het bouwen van stuwdammen: "Whereas the construction of dams for hydroelectric or other projects is often achieved without appropriate scientific study of the effects of such works on other natural resources, and whereas it is possible that the management of one natural resource of any kind can seriously affect other resources of equal or superior value; therefore the Assembly recommends that the International Union for the Protection of Nature should make an insistent appeal that for all new proposed construction careful studies of all the resources should be made - if they do not already exist - before any plans for the construction or execution of such an enterprise shall be decided."'1

Dr. D. C. GeijSkES, gedelegeerde van Suriname bij de Caracasconferentie, deed na afloop een verslag aan de Landsregering toekomen, waarin onder meer de resoluties op het gebied van stuwmeren in beschouwing werden genomen. Hij en zijn medegedelegeerde van de Nederlandse Antillen, Dr. J. H. Westermann, bezochten in februari I 953 - na overleg met de landsminister van Algemene Zaken - de locatie Afobaka waar de stuwdam in de Suriname-rivier was geprojecteerd. Kort daarop, in maart 1953, bood het bestuur van de Studiekring aan de Surinaamse Regering

1 Hier mag worden gewezen op het artikel "A dam across the Amazon" van Robert B. PANero in Science Journal (september 1969, p. 56-60). Daarin wordt gepleit voor een project van een reeks stuwmeren, dat een gebied zo groot als de U.S.A. voor ontwikkeling zou openleggen en onvoorstelbaar grote hoeveelheden hydroëlectriciteit zou opleveren. Over de ecologische consequenties en risico's van het plan wordt door de auteur heengestapt. Typerend is zijn opmerking: "We would expect none of these risks to prevent construction of the dam. Such risks are present in all dams and reservoirs and have never really prevented any from being built". 
de bovenbedoelde nota aan, getiteld Beschouwingen naar aanleiding van het Combinatie-plan Van Blommestein (c.q. Brokopondoplan) voor de Suriname-rivier. In deze nota zijn de technische, economische en financiële aspecten niet in beschouwing genomen maar wordt wel naar voren gebracht dat het project te veel technisch is geconcipieerd en nauwelijks of geen rekening houdt met de ecologische consequenties, d.w.z. met de ingrijpende veranderingen die zullen optreden in de bestaande levensgemeenschappen van water en land en van de Bosnegerbevolking. Aan de Regering werd tenslotte geadviseerd om een commissie van deskundigen te benoemen met opdracht om in samenwerking met de Stichting Planbureau Suriname en in overleg met ervaren buitenlandse organisaties "advies uit te brengen over de natuurwetenschappelijke consequenties van het stuwdammenproject, alsmede om, zover doenlijk, richtlijnen aan te geven ter correctie van de te verwachten moeilijkheden, die tijdens en na de uitvoering der voorgestelde werken, in het betrokken deel van het binnenland van Suriname zullen ontstaan. Zulk een advies zal dus naast de technische en economische plannen en naast de sociologische en medische vraagstukken, de natuurwetenschappelijke problemen in het totale plan moeten belichten."

Ook van de zijde van de VerEniging van WeTENSCHAPPELIJKE WeRKERS IN SURINAME werd aangedrongen op een niet uitsluitend technisch-economisch vooronderzoek.

De Regering volgde de adviezen aanvankelijk op en stelde in augustus I953 bij Resolutie de BROKOPONDO-RAAD in voor het dienen van advies, onder voorzitterschap van de directeur van het Planbureau; later werd de naam gewijzigd in STUDIERAAD BROKOPONDO-PLAN. Van de Raad maakten de bij het plan betrokken Departementsdirecteuren en Hoofden van Dienst deel uit. Een subcommissie werd samengesteld voor de bestudering van de natuurwetenschappelijke consequenties, onder voorzitterschap van Dr. D. C. GeijSkEs, alsmede een subcommissie voor de bestudering van de verplaatsing van de bevolking uit het stuwmeergebied onder voorzitterschap van Drs. J. Michels. Het Programma gedateerd 20 januari 1954 van eerstgenoemde subcommissie bevatte voorstellen voor een bodemkundige, botanische, zoölogische, hydrobiologische, hydrologische en meteorologische opname van het te inunderen gebied en een bestudering van het verloop van de verstoring van het natuurlijk evenwicht tijdens en na de inundatie. De andere subcommissie nam op zich het inventariseren van de in het te inunderen terrein wonende bevolking en de beschik- 
kingskringen van hun lo's, en een sociologische, medische en economische evaluatie van de transmigratie (2I januari I954).

Op I december I953, tijdens een vergadering gehouden ten kantore van de Stichting Planbureau Suriname, 's-Gravenhage, werd besloten dat door de Studiekring een vergelijkend literatuuroverzicht zou worden samengesteld, als eerste stap op weg naar een programma van veldonderzoekingen. Dank zij een belangrijke financiële bijdrage van het Planbureau kon reeds in januari 1954 een begin worden gemaakt met de literatuurstudie en wel door de biologisch doctorandus J. P. SchULZ van de Utrechtse universiteit.

Het rapport van ScHuLz, getiteld Vergelijkend literatuuronderzoek inzake de ecologische consequenties van het 'Combinatie-Plan Suriname Rivier' verscheen op I oktober I954 als uitgave van de Studiekring. Deze doorwrochte literatuurstudie bevat tot in details gaande analyses van ecologische aspecten naar analogie van elders verrichte onderzoekingen en opgedane ervaringen. Behalve een algemeen hoofdstuk bevat het rapport hoofdstukken over de te inunderen vegetatie en de te verwachten plantengroei in het stuwmeer, de betekenis van de vegetatieveranderingen voor de hydrologie (evapotranspiratie), de bestrijding van de plantengroei in het meer, de invloed van de stuwdam en het meer op de visstand, en de problemen van de volksgezondheid in het bijzonder wat betreft malaria, filariasis, gele koorts, dengue en schistosomiasis. Bovendien vestigde ScHuLZ de aandacht op de noodzaak van een juist beheer van bos, bodem en water in de wijde omgeving van het stuwmeer, een gerichte 'watershed management' ten behoeve van het hydrologisch regime van het meer zelf. Natuurwetenschappelijke en volksgezondheidsvoorstudies in het Surinamerivier-stroomgebied zouden volgens hem in een zo vroeg mogelijk $\zeta$ stadium moeten worden uitgevoerd. Een korte bespreking van het rapport werd gegeven door J. H. DE HAAN (I955).

/ Hoewel Schulz' rapport in ruime mate werd verspreid onder autoriteiten en belangstellenden in Suriname heeft het, behalve enige kritiek van medische zijde (3 februari I955), nauwelijks aandacht gekregen. Men kan zelfs zeggen dat verschillende voorstanders van de bouw van een stuwdam het een onaangename zaak vonden dat van natuurwetenschappelijke zijde werd opgekomen tegen een uitsluitend technisch-economische aanpak: de aanbevolen onderzoekingen zouden immers de voortgang van het begeerde project aanzienlijk kunnen traineren en mogelijk een af- 
stel bewerken. Aan de in het rapport naar voren komende adviezen werd geen gehoor gegeven; er werd geen initiatief genomen tot het doen van ecologische voorstudies.

Ook van andere zijde kwamen bezwaren tegen de uitvoering van het Brokopondo-project. De houtvester J. W. GonGGRYP (I955, I956) stelde tegenover de hydro-electrische energieopwekking de, volgens globale becijfering, ongeveer even dure energieopwekking uit brandhout, waarbij geen inundatie en geen transmigratie van bevolking nodig zouden zijn; een onderzoek daarnaar werd door hem bepleit. Dat - volgens een memorandum van Ir. R. ZoNNEveld van 24 april I956 - het Planbureau GoNGGRYP's voorstellen onaanvaardbaar vond en evenzo een kernenergiecentrale, lag, mede gezien de vergevorderde plannen voor het stuwmeer, voor de hand. In een bijeenkomst op I5 juni I956 van de Vereniging van Wetenschappelijke Werkers in Suriname is door beide deskundigen een openbare discussie gehouden over het onderwerp 'waterkracht versus houtstook in tropisch regenbos' (zie o.a. de dagbladen Suriname en Het Nieurs, r6 juni 1956).

Intussen werden de technische voorbereidingen en de financieeleconomische besprekingen voortgezet terwijl de ecologische en sociologische aspecten niet of maar nauwelijks aan de orde kwamen. Dit was reden voor de Studiekring om - toen verschillende berichten wezen op spoedig te nemen beslissingen - nogmaals een kritisch geluid te laten horen. In Een korte beschouwing over het $\leftarrow$ Brokopondo-plan (WeSTERMANN I956) is er op gewezen dat in landen waar reeds jaren lang rivieren zijn afgedamd voor waterkrachtwerken en andere doeleinden, deze projecten vaak de toets der kritiek niet hebben kunnen doorstaan. Mede aan de hand van een in 1952 verschenen artikel 'Hydro-electric power and renewable resource conservation' van A. W. SмIтн, Executive Secretary of the Committee on Regional Development and Conservation, Washington (in I954 en I955 opnieuw uitgegeven door I.U.P.N.) stelde de auteur dat voor het Brokopondo-plan niet alle aspecten zijn bekeken en gewogen. Hij voegde daaraan toe: "Er is vrijwel niemand die zich voor ogen kan stellen wat de balans is tussen hetgeen vernietigd en hetgeen gewonnen zal worden. Als stuwmeerproject is dat van de Suriname rivier uiteraard onaantrekkelijk, omdat, als gevolg van de topografische gesteldheid, een zeer groot en ondiep meer geschapen moet worden om de energie te kunnen leveren voor een aluminiumbedrijf." $\mathrm{Er}$ is onzekerheid over de waarde van het stuwmeer na enige tientallen jaren, ge- 
zien de onzekere toekomst van het aluminiumfabricagebedrijf. Aannemende dat het Brokopondo-plan technisch mogelijk is maar economisch marginaal, werd voorts de vraag gesteld waarmee Suriname op den duur het meest gebaat zal zijn: "met een snelle en in zijn geheel gezien onvoldoende voorbereide bouw van een stuwdam of met een langzamere maar meer evenwichtige ontwikkeling van het stroomgebied."

De nota van de Studiekring vond weerslag in de pers, o.m. in het Algemeen Handelsblad van 16 maart en de A.N.P. Westindische Documentatie Dienst van 22 maart 1956; kritisch commentaar op de nota verscheen in het Algemeen Handelsblad van 21 maart en de A.N.P. Westindische Documentatie Dienst van 29 maart van de hand van Prof. Dr. R. A. J. van LIER. In het Algemeen Handelsblad van 23 maart en de A.N.P. Westindische Documentatie Dienst van 29 maart uitte de oud-directeur van de Surinaamsche Bauxite Maatschappij, Ir. O. M. DE MUNNICK, kritiek op het stuwmeerplan, mede naar aanleiding van in 1924-1925 door Alcoa verzamelde gegevens. Ook de beschouwingen van J. W. GoNGGRYP over hout als brandstof voor een centrale werden weer in de pers vermeld (Algemeen Handelsblad van 3 januari, Suriname van 9 januari, De West van 16 januari 1956).

De technische en economische voorbereiding ging echter ongestoord verder, hetgeen resulteerde in de Brokopondo-overeenkomst van 27 januari 1958 .

De Brokopondo-overeenkomst leidde echter wel tot enkele activiteiten en studies van niet-technische en niet-economische aard. Vooreerst moet daarvan genoemd worden de door Districtscommissaris Drs. J. Michels op I december 1958 afgesloten rapportage over de noodzakelijke transmigratie van Bosnegers uit het stuwmeergebied, de daarmee samenhangende ontwrichting van de bestaande eigen maatschappelijke orde van - naar verwachting 2I Saramaccaanse dorpen met totaal 3900 inwoners, en 4 Aucaner dorpen van bijna II00, en de sociale implicaties van het scheppen van nieuwe woonplaatsen bovenstrooms en benedenstrooms onder een meer directe bestuursvorm. Een in $195^{8}$ door de Stichting Wetenschappelijk Onderzoek Suriname - NeDERLANDSE ANTILLEN (WOSUNA) gefinancieerd sociologisch onderzoek door Dr. F. A. E. vaN WoudEN naar het gebruiksrecht van gronden en wateren toebehorende aan verschillende lo's, moest ontijdig afgebroken worden en bleef zonder resultaat. Michels' advies luidde dan ook dat het bestuurspersoneel van het nieuwe district Brokopondo zo spoedig mogelijk tot een inventarisatie van dit recht zou moeten overgaan, teneinde bij de transmigratie rekening te kunnen houden met de van ouds be- 
staande indelingen. Deze inventarisatie zou ook de registratie van de bevolking, gebouwen, begraafplaatsen, kostgronden en beplantingen moeten omvatten, mede met het oog op schadevergoeding.

Namens het bestuur van de Stichting Surinaams-NederLANDS INSTITUUT VOOR DE VOLKSGEZONDHEID IN SURINAME (SUNEVO) richtte in 1959 de hoogleraar in de medische fysiologie te Leiden, Dr. J. W. DuYFF, zich tot de Minister van Sociale Zaken en Volksgezondheid van Suriname met een waarschuwing ten aanzien van de door de vorming van het stuwmeer op te treden ernstige verstoringen van biologische evenwichten, alsmede wat betreft de medische gevaren van de concentratie van arbeiders van verschillende landsaard en uit verschillende streken, met onderling verschillende infectie-, infestatie- en immuniteitspatronen, en van de transmigratie van de bevolking. DUYFF constateerde dat het te laat was om een gedegen biologisch, medischhygiënisch en epidemiologisch vooronderzoek te ondernemen en dat op het stuwprogramma geen invloed meer mogelijk was. Desniettegenstaande adviseerde hij - wijzende op de in lid 3 (a) van artikel I van de Brokopondo-overeenkomst door Suriname aangegane verplichting om "de technische hygiëne in en de assainering van het gebied van het stuwmeer te verzekeren en te handhaven" - vóór eind I96o een minimumprogramma uit te voeren. Dit programma zou moeten bestaan uit entomologisch-malariologische, epidemiologische en geneeskundige onderzoekingen en op basis daarvan zouden maatregelen moeten worden genomen op het gebied van technische hygiëne, assainering en transmigratie.

DUYFF's adviezen werden - anders dan bij de natuurwetenschappelijke en sociologische desiderata - althans ten dele ter harte genomen.

In een doorwrocht mede op literatuur gebaseerd rapport aan de Stichting SUNEVO heeft de Leidse parasitoloog Prof. Dr. P. H. VAN THIEL - die in februari I96o daarvoor naar Suriname ging en geassisteerd werd door de geneesheer H. R. G. Asin van het Bureau voor Openbare Gezondheidszorg - De malariaproblematiek in verband met de uitvoering van het Brokopondo-project beschreven (1960). Achtereenvolgens wijdde hij beschouwingen aan het waterniveau, de oever en de bodem van het te vormen stuwmeer, de biologie en het voorkomen van Anopheles darlingi in Suriname, de geschiktheid van het meer als broedplaats van $A$. darlingi en andere Anophelinen en de kansen van het broeden in het meer, maatregelen om het broeden tegen te gaan, verwachtingen om- 
trent malariagevallen vóór en na de inundatie, maatregelen ter voorkoming van malaria bij de bevolking in het stuwmeergebied met voorstellen voor het uitvoeren van een radicaal, een minimum en een compromis-programma. Een uitvoerige literatuurlijst is toegevoegd. Een gedrukte publikatie verscheen in Tropical and Geographical Medicine (1962).

Kort daarna, eind I96I, bracht VAN THIEL opnieuw een rapport uit aan SUNEVO, deze keer over De kans op infectie met filaria en schistosoma in hetzelfde gebied, eveneens met literatuurlijst. Maatregelen werden voorgesteld ter voorkoming van deze infecties tijdens de dambouw en in eventuele latere vestigingen aan het stuwmeer.

In dit verband moeten ook genoemd worden de onderzoekingen door de arts H. R. G. Asin en diens proefschrift (I962), onder promotorschap van Prof. vaN THIEL, over De invloed van het contact tussen stads- en boslandbevolking op de epidemiologie van parasitaire darminfecties, in verband met de bouw van de Brokopondo-stuwdam. (Zie ook Asin \& van ThIEL I963).

$\rightarrow$ De Surinaamse ministerraad belastte op 8 februari I96o, slechts zes maanden voordat met de bouw van de dam in Afobaka een begin werd gemaakt, het - op 5 maart 1955 opgerichte en onder het Departement van Landbouw, Veeteelt en Visserij staande BUREAU LANDELIJKe OpBouw met het opstellen van een ontwikkelingsplan. In zeer korte tijd werd door dit Bureau een tamelijk gedetailleerd Prae-advies inzake het Streekplan Brokopondo uitgebracht (april I960), dat naast de opsomming van algemene gegevens over het gebied en de bevolking, de consequenties belicht van de bouw van het waterkrachtwerk voor het milieu en de bevolking, en richtlijnen geeft voor de verdere ontwikkeling op het gebied van landbouw, jacht en visserij, bosbouw, mijnbouw, industrie, recreatie, toerisme, ontsluiting, transport, werkgelegenheid, onderwijs-, gezondheids- en planologische voorzieningen; ook het kostenvraagstuk en de bodembestemming (met kaart) werden aan de orde gesteld. Naar eerdere rapporten en publikaties is niet verwezen.

Het programma van handelen in het prae-advies vermeldt als punten van 'eerste urgentie' de bevolkingstransmigratie, sociale voorzieningen voor de gehele boslandbevolking, onderzoek naar de sociale structuur van de Bosnegergemeenschap, geneeskundige verzorging van de plaatselijke bevolking, onderwijs, onderzoek naar de medische consequenties van het stuwmeer, beleid ten 
aanzien van zending en missie, watertransport over het meer, overslaghaven bij de stuwdam, houtlift bij de stuwdam, invloed van het meer op de bevaarbaarheid van de Suriname-rivier benedenstrooms, mede tijdens de opvulperiode, opheffing van de spoorlijn Brownsweg-Kabel, wegenplan, centrumplan, plaatsbepaling van het centrum Paralumna, voedsellandbouw en boomgewassenteelt bij de Bosnegerbevolking, kostenraming van het streekplan Brokopondo.

Als punten van 'tweede urgentie' werden geacht de controledienst op het meer, onderzoek naar het waterkrachtpotentieel van de Saramacca-rivier en de Tapanahony, onderzoek naar de toekomstige zoutgrens in de Suriname-rivier, een vliegveld bij Goddo, een stedebouwkundig plan voor het centrum Paralumna, bevordering van de huisnijverheid onder de boslandbevolking, opleiding van verplegend personeel en onderwijspersoneel voor het binnenland, een bodemkundige overzichtskaart, bescherming van de fauna tijdens de inundatie.

De punten van 'derde urgentie' waren het onderzoek naar de aanleg van een railbaan langs de vallen tussen Pokigron en Goddo, het vaststellen en inrichten van recreatie- en toeristencentra, de exploitatie van het houtbestand in het stuwmeerrandgebied, de geologische inventarisatie rondom het meer, onderzoek naar het voorkomen van economisch winbare steen, vestigingsmogelijkheden van industrieën, en een definitief bodembestemmingsplan.

Wat het eigenlijke meer betreft, wijst het prae-advies er op dat het zeer grillig van vorm zal zijn en talrijke kleine eilanden zal bevatten. Daardoor zal de totale oeverlijn, de eilanden inbegrepen, onevenredig lang worden, namelijk circa $2000 \mathrm{~km}$. De normale seizoenschommelingen in waterpeil werden geschat op $\mathrm{I}^{1} / 2$ à 3 meter, maar bij extreem droge perioden zouden grote dalingen kunnen optreden, tot ro meter beneden het maximumpeil, waardoor zeer grote arealen in de over het algemeen slechts flauw hellende oeverzones zullen droogvallen. Ook over de bevaarbaarheid en toegankelijkheid van het meer en de mogelijkheid van het ontstaan van uitgestrekte broedplaatsen van malariamuskieten was het prae-advies niet optimistisch: "Men kan voor zeer onaangename verrassingen komen te staan, die van invloed kunnen zijn op het economisch nut van het stuwmeer en omgeving."

WAGENAAR Hummelinck (I96I) prees het bovengenoemde prae-advies om "de duidelijke taal die wij zo gaarne een tiental jaren geleden van officiële zijde hadden gehoord". Maar hij vroeg 
zich tevens af: "Is de bezorgde toon welke in dit rapport naar voren treedt er wellicht de oorzaak van dat dit advies tot dusver zo weinig bekendheid heeft gekregen? Of beschouwt men de maatregelen welke hierin met klem worden aanbevolen als grotendeels onuitvoerbaar, of zelfs ongewenst, omdat zij de snelle voortgang van het Brokopondoplan zouden kunnen afremmen?"

Hoe het zij, het Prae-advies had een oriënterend karakter en formuleerde in algemene zin de problematiek van het gebied. Gezien de geringe beschikbare tijd en mankracht is het niet te verwonderen dat slechts aan enkele van de zeer vele punten meer dan oppervlakkige uitvoering kon worden gegeven.

Door Ir. G. P. Tiggelman, Directeur van het Ministerie van Landbouw, Veeteelt en Visserij, werd ter gelegenheid van de komst van de E.E.G. Commissie in april I962 een voorlopig 5jarig Ontwikkelingsplan voor het Brokopondo-gebied opgesteld, met projecten voor onderzoek naar de ecologische consequenties van het stuwmeer, voor ontwikkeling van bevolking, landbouw, bosbouw en industrie, voor ontsluiting en voor recreatie. Het plan heeft de E.E.G. niet bereikt.

Ook de ichthyoloog Hoedeman (I962) heeft een, zij het summier overzicht gegeven van de biologisch-oecologische factoren die de waarde van het stuwmeer en het wijdere milieu nadelig kunnen beinvloeden, zoals de vorming van broedplaatsen van ziekteoverbrengers, wegvallen van benedenstroomse overstromingsgebieden van belang als paai- en voedingsgronden voor vissen, verlanding en vergrote verdamping vanwege de drijfplanten.

Niet lang vóór de sluiting van de dam, in december 1963 , deed de Vereniging voor Dierenbescherming te Paramaribo in haar tijdschrift een oproep om gelden te geven voor een dierenreddingsactie in het te vormen stuwmeer. De StICHTING 'TJALI OE DE GwAMBA' (Saramaccaans voor 'Hebt medelijden met het bosdier') werd 28 maart I964 opgericht door de Minister van Algemene Zaken, met het doel die reddingsactie te organiseren en te financieren. De belangrijkste steun kwam van de zijde van de InTERnational Society FOR THE PROTECTION OF ANimals, Boston. John Walsh van deze Society, de bestuursambtenaar ROB DE BRUIN en hun Bosnegerhelpers werkten van augustus I 964 tot en met december 1965 en redden ruim 9700 dieren van de verdrinkings- en hongerdood; deze dieren werden vrijgelaten op veiliger plaatsen rondom het stuwmeer, dat met zijn eilanden en oeverstrook ter breedte van Io $\mathrm{km}$ bij Landsbesluit van 2 oktober 
I964 tot gebied werd verklaard waarvoor de Jachtverordening I954 van toepassing is en waar de jacht voor vijf jaren geheel werd verboden (Michels i965, Sмiтh I966, Walsh i967). Op 3 oktober 1969 werd het gebied - zij het met de gewone wettelijke beperkingen - weer voor de jacht opengesteld, hetgeen volgens Suriname. Feiten en Cijfers (september I969) "een extra attraktie bij de rekreatie-mogelijkheden die in het stuwmeergebied reeds geboden worden" betekent.

Beschouwingen over o.m. de watervulling en waterverliezen van het meer aan de hand van de hem beschikbare gegevens werden in 1966 , I967, 1968 en I969 door J. W. GoNGGRYP gegeven. Ten aanzien van de nota van 1966 werd door de adjunct-directeur Ir. W. C. VISSER van het Instituut voor Cultuurtechniek en Waterhuishouding, Wageningen (Nederland), waardevol commentaar geleverd (3 november 1966). GoNGGRYP constateerde dat het waterkrachtwerk de volle capaciteit niet heeft bereikt; volgens opgave van Suralco van 3I mei 1969 was het hoogst bereikte percentage van het productievermogen van de aluminiumsmelter iets meer dan 70 . Volgens hem zijn de cijfers betreffende het peil van het meer en van de toevoer van water verminderd met de afvoer, in verband met de afmetingen van het meer, zodanig dat het onwaarschijnlijk is dat het volle productievermogen ooit gehaald wordt. De peilschommelingen maakten het mogelijk een denkbeeld te krijgen van de verliezen aan water door evapotranspiratie en eventuele kwel gezamenlijk; deze werden geschat op $20 \%$ van de watertoevoer aan het meer. Gegevens over elk van deze factoren afzonderlijk kunnen pas verkregen worden na veel gedetailleerd onderzoek.

\section{HET NATUURWETENSCHAPPELIJK ONDERZOEK, I $962-{ }^{1} 969^{1}$}

Op 7 januari 1962 verzocht Dr. F. P. JonKeR, hoogleraar aan de Rijksuniversiteit te Utrecht, aan de Stichting WetenschapPELIJK Onderzoek Suriname-Nederlandse ANTIllen (WOSUNA), te Amsterdam, en de NatUURWetenschappelij Ke

1 Er moet hier met nadruk op worden gewezen dat het onderzoek niet is opgezet uit hoofde van de in het vorige hoofdstuk gesignaleerde risico's van het stuwdamplan. Het is uitgevoerd als zuiver-natuurwetenschappelijk project, bedoeld om zoveel mogelijk te weten te komen van de veranderingen in flora, fauna en hun fysisch-chemisch milieu tijdens en na de stuwmeer-vorming. 
Studiekring voor Suriname en de Nederlandse Antillen, te Utrecht, bij de Surinaamse Regering aan te dringen op de oprichting van een Wetenschappelijk Stuwmeer Instituut. Professor JoNKER stelde dat door het Brokopondo-project op zeer grote schaal werd ingegrepen in een natuurlijk landschap zonder dat men zich, afgezien van de technische aspecten, precies een voorstelling kon maken van de optredende veranderingen. Hij beschreef het plan als een enorm biologisch experiment, te vergelijken met de afsluiting en gedeeltelijke drooglegging van de Zuiderzee in Nederland. Evenals het geval was met laatstgenoemd project zouden in het Brokopondogebied de milieuveranderingen en de daaruit voortvloeiende biologische verschuivingen op de voet moeten worden gevolgd door een team van deskundigen, mede met het oog op eventuele volgende stuwmeerprojecten.

Een bespreking van genoemd voorstel door bestuursleden en adviseurs van de Studiekring op I8 januari I962, te Utrecht, leidde niet tot een besluit om de Surinaamse Regering ter zake te adviseren. Wel werd, na overleg met Dr. P. WAGENAAR HummeLiNCK, op 5 juli door Dr. J. H. Westermann een minder ver gaand voorstel ingediend tot het detacheren van een bioloog, bij voorkeur een limnoloog, bij het Brokopondo-project, voor het doen van waarnemingen met betrekking tot de oecologische consequenties van de vorming van het stuwmeer voor flora en fauna; daarbij werd mede verwezen naar het rapport van ScHULz (I954) en enkele in I960 en 196I verschenen artikelen over het project. De reacties op dit voorstel waren dermate positief dat op 28 augustus daaropvolgend door de Studiekring bij WOSUNA een subsidieaanvraag werd ingediend voor genoemd onderzoek. Het WOSUNA-bestuur legde de aanvraag voor aan de Commissie van Advies te Paramaribo, die op 9 oktober aan het plan de hoogste prioriteit toekende. Op 20 november 1962 besloot WOSUNA aan de Studiekring voor 1963 een subsidie van maximaal $\mathrm{N} f 40.000$ toe te kennen.

WOSUNA zette de financiële steunverlening in 1964 voort; op 28 november 1963 werd aan de Studiekring een subsidie verleend van $\mathrm{N} f \mathbf{1 2 0 . 6 0 0 .}$

Nadat WOSUNA had opgehouden te fungeren, in verband met de oprichting op 3 juli 1964 van de STICHTING vooR WeTENSCHAPPELIJK ONDERZOEK VAN DE TROPEN (WOTRO), werd de subsidiëring door WOTRO overgenomen: $\mathrm{N} f$ I 14.000 voor 1965 (29 december 1964$)$; $f f$ I37.00o voor I966 (7 januari I966); $\mathrm{N} f 80.000$ voor 1967 (20 december I966), later verhoogd met $f 4.000$ (27 september 1967).

Voorts ontving de Studiekring subsidies van WOTRO voor korte be- 


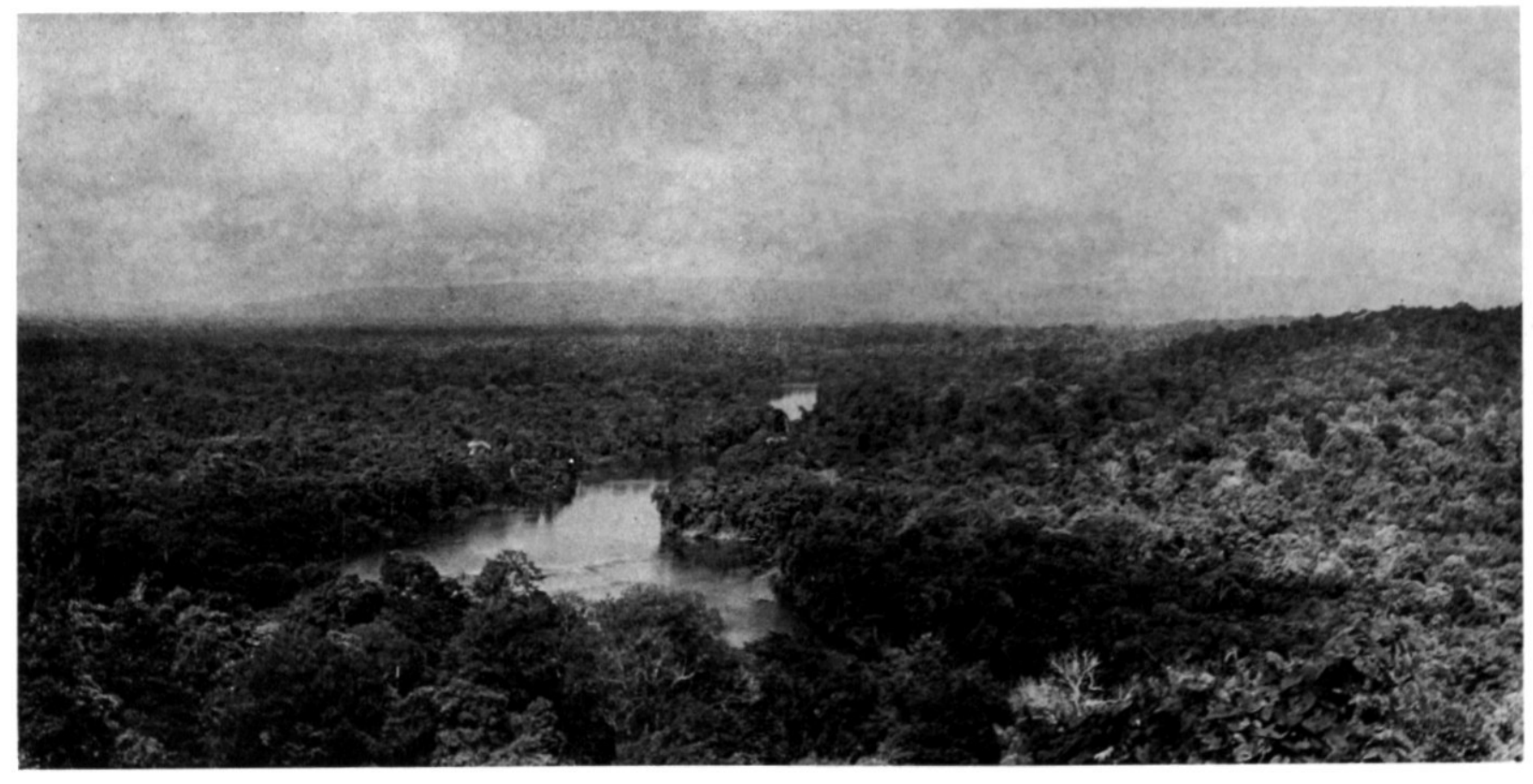

Plaat I. Uitzicht van een heuvel Oost van de stuwdamlocatie naar het Zuiden, vóór de vorming van het Brokopondomeer. Op de achtergrond. over het dal van de Suriname-rivier, ziet men de Erownsberg. [Foto: Ir. F. C. Bubberman, sept. 1954 


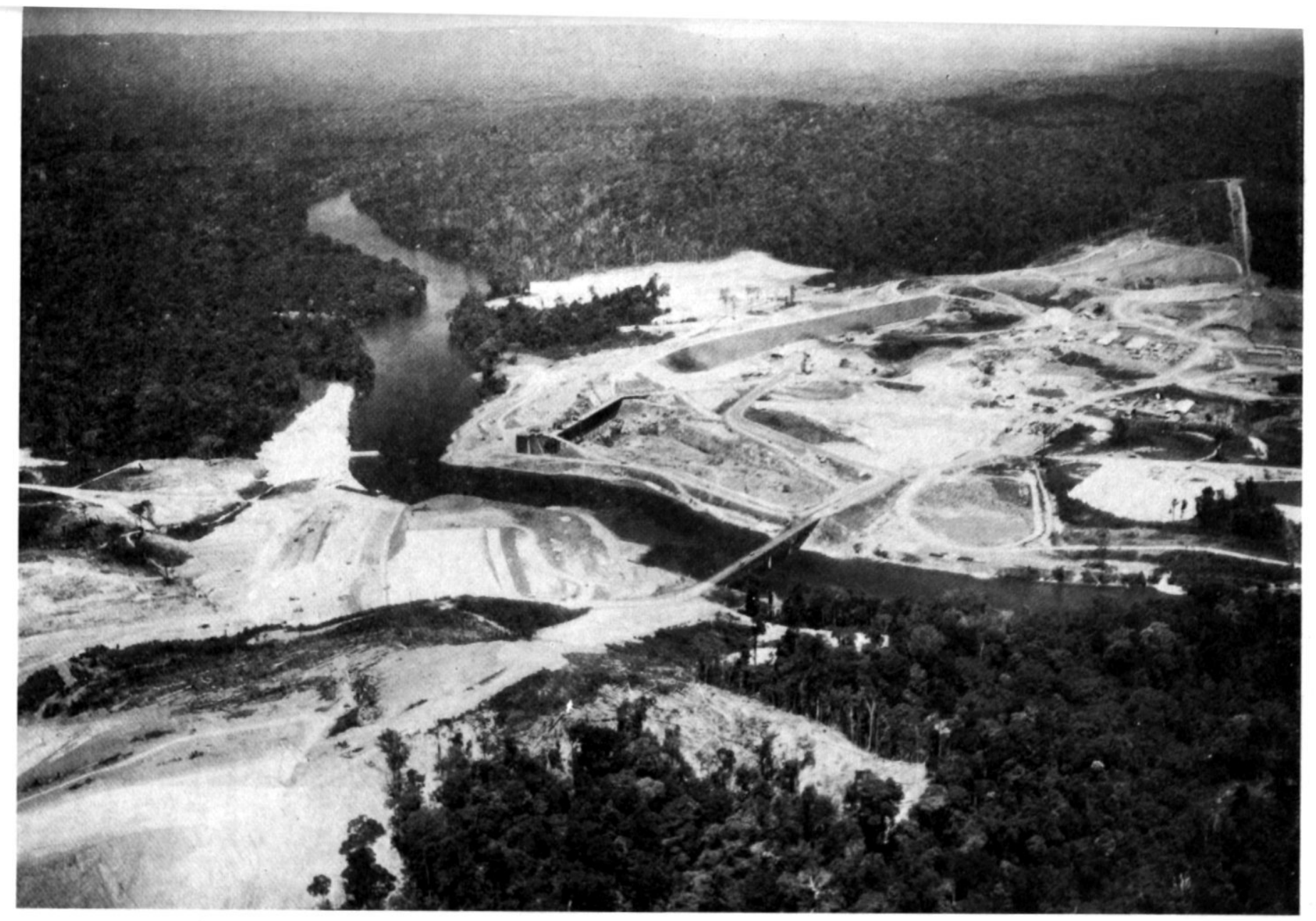

Plaat II. Het begin van de stuwdam-constructie. Uitzicht over het toekomstige stuwmeergebied naar het Zuiden; vgl. Pl. I. De brug welke benedendams is aangelegd vindt men op Plaat III, IV, VI, VII en IX terug. [7 sept. 1962] - Deze foto en alle volgende afbeeldingen werden gemaakt door het Centraal Bureau Luchtkartering Suriname. 


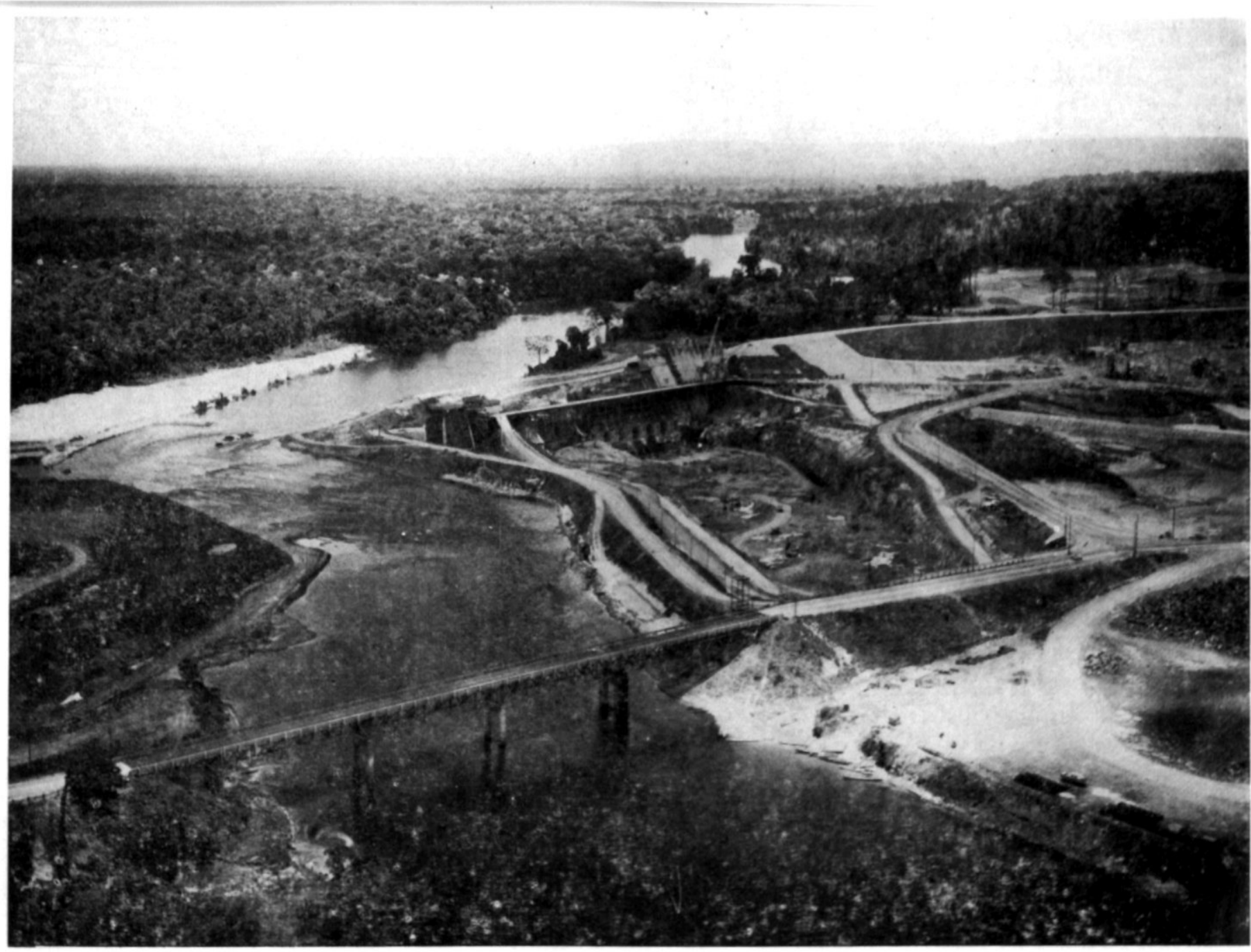

Plaat III. De stuwdam in aanleg, vijf-en-een-half jaar nadat de 'letter of intent' door de Staten van Suriname werd bekrachtigd. [7 sept. 1962] 


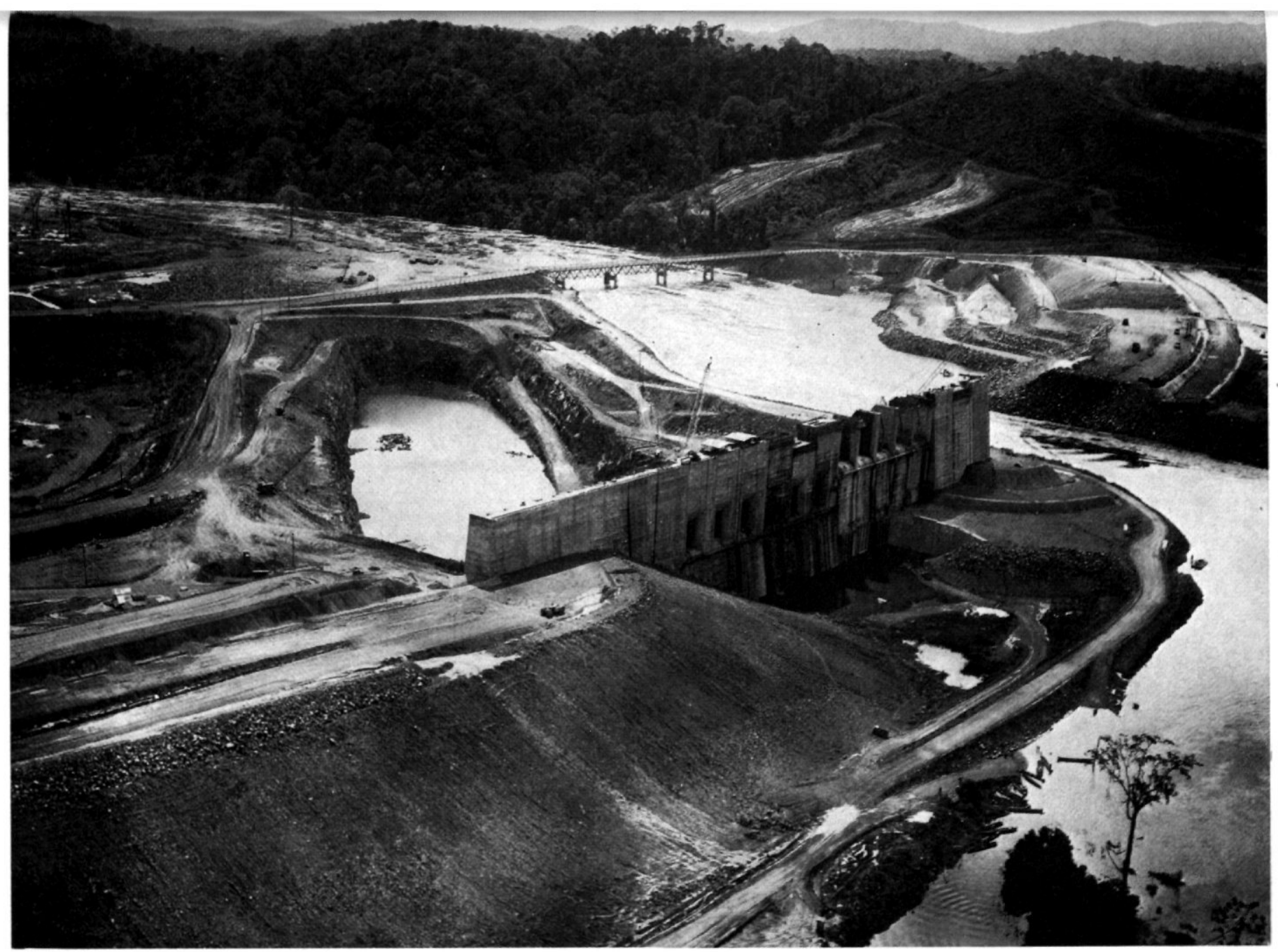

Plaat IV. Het grote werk in aanleg, naar het Zuiden gezien, acht maanden vóór de afsluiting van de Suriname-rivier. [8 juni 1963] 


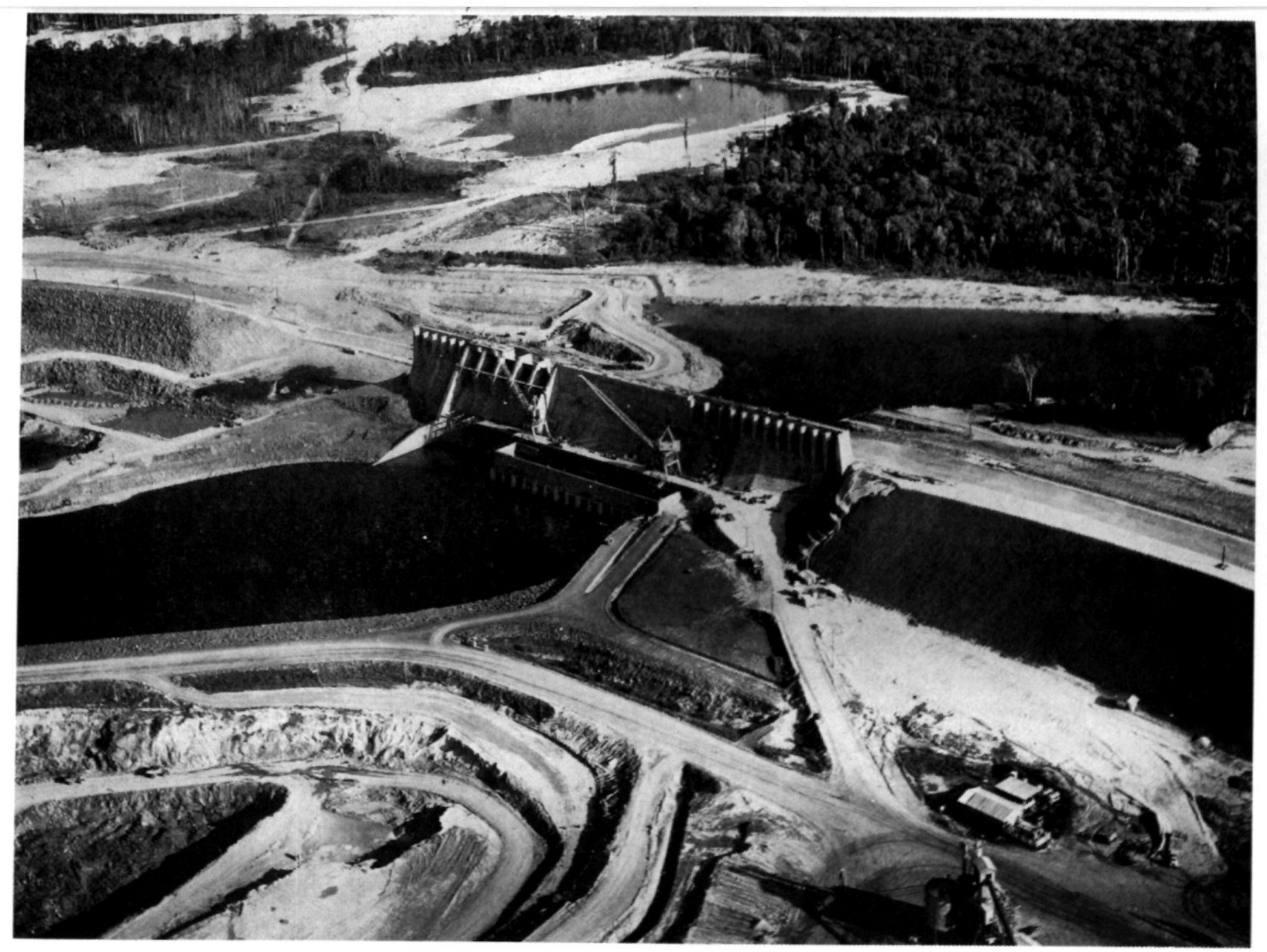

Plaat V. Het waterkrachtwerk, naar het Noordwesten gezien, drie-eneen-halve maand vóór de afsluiting van de rivier. [1 7 sept. 1963] 


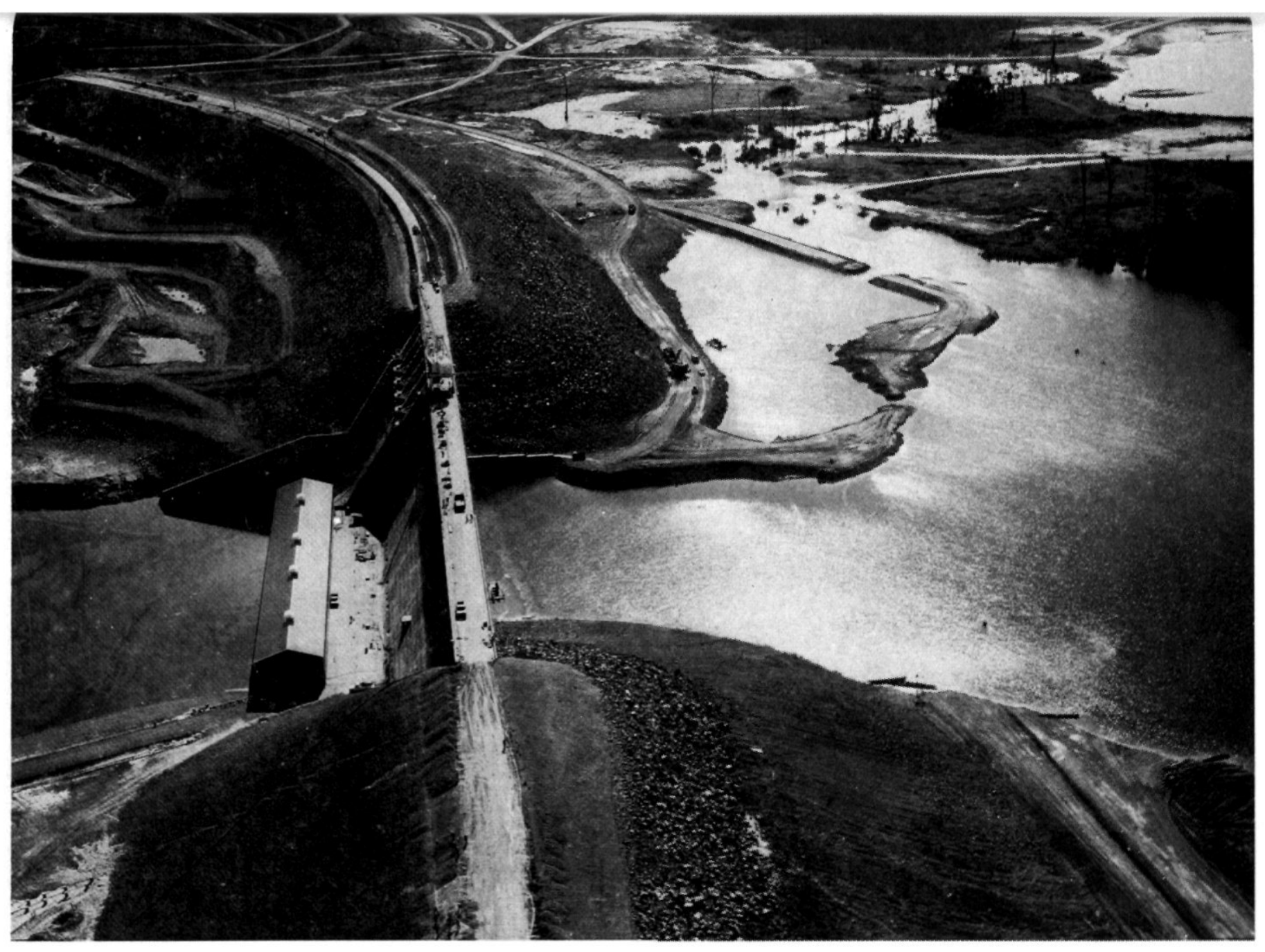

Plaat VI. Tien dagen na de afsluiting: het waterpeil bovenstrooms stijgt snel! [I I febr. r964] 


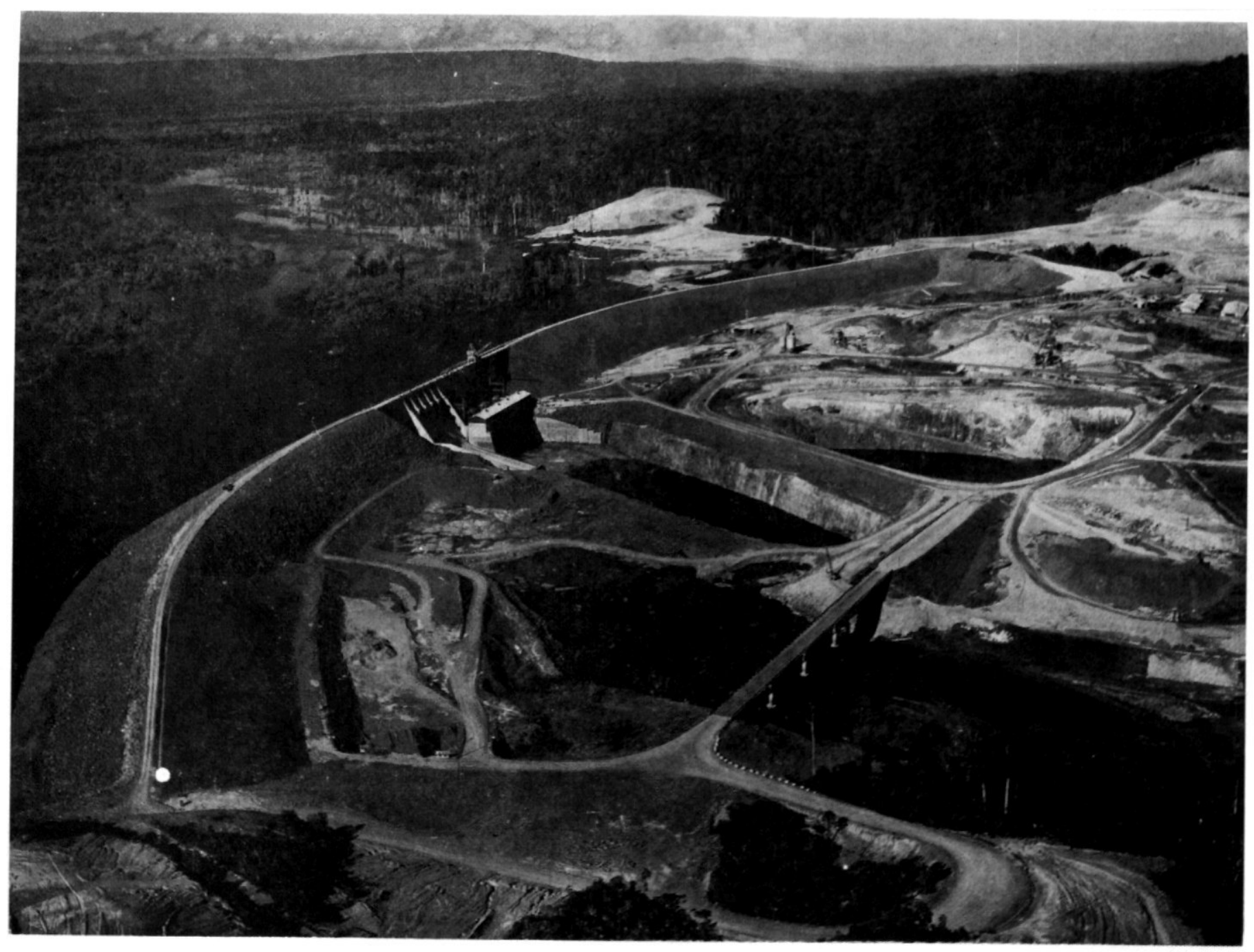

Plaat VII. Na negen maanden staat al een flink gedeelte van het bovenstroomse bosgebied onder water. Slechts een klein deel van het terrein werd tevoren schoongemaakt. [ 26 nov. I964] 


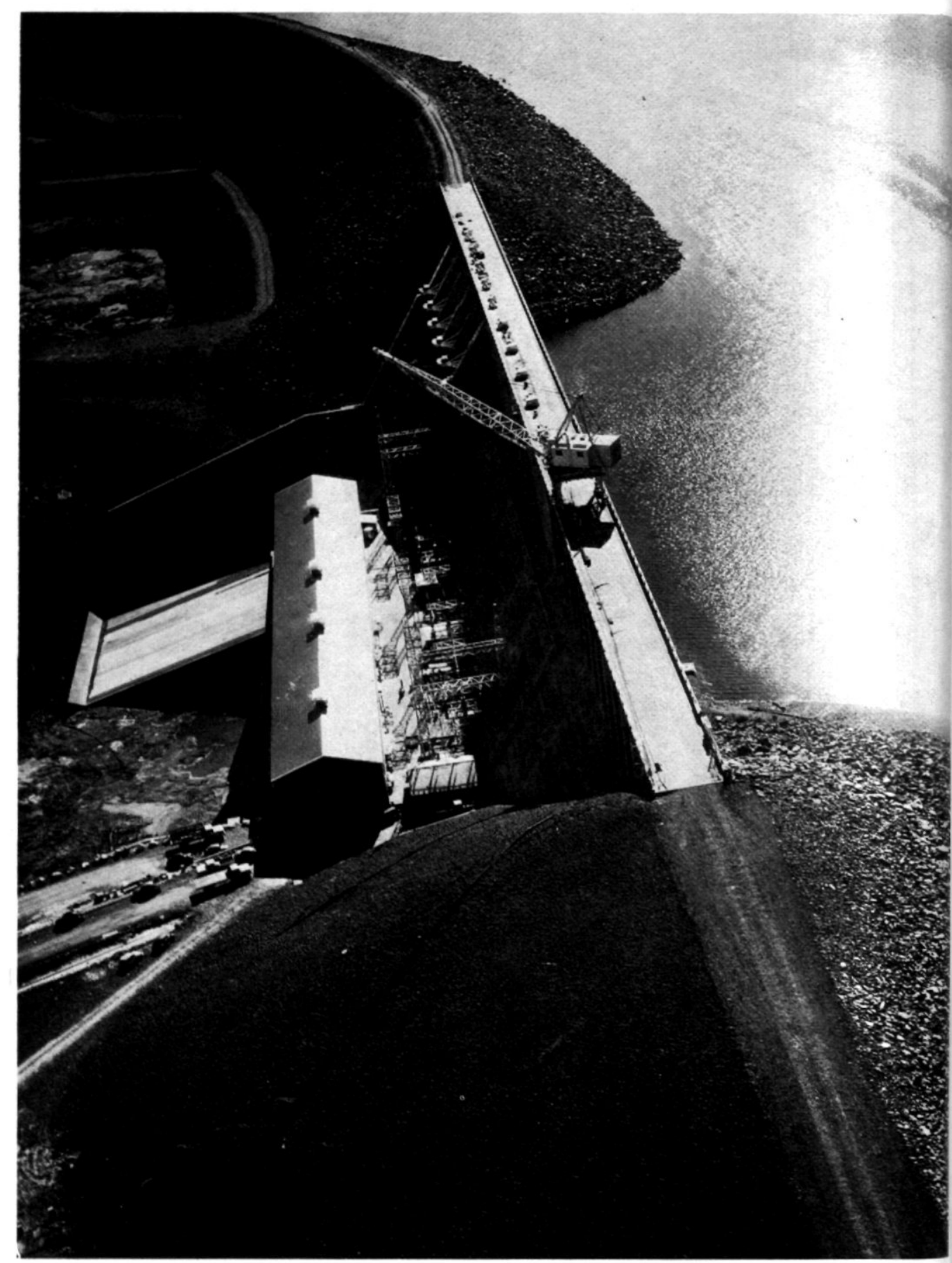

Plaat VIII. Negen maanden na de afsluiting ziet men al een enorm verschil in waterstand. [26 nov. 1964 ] 


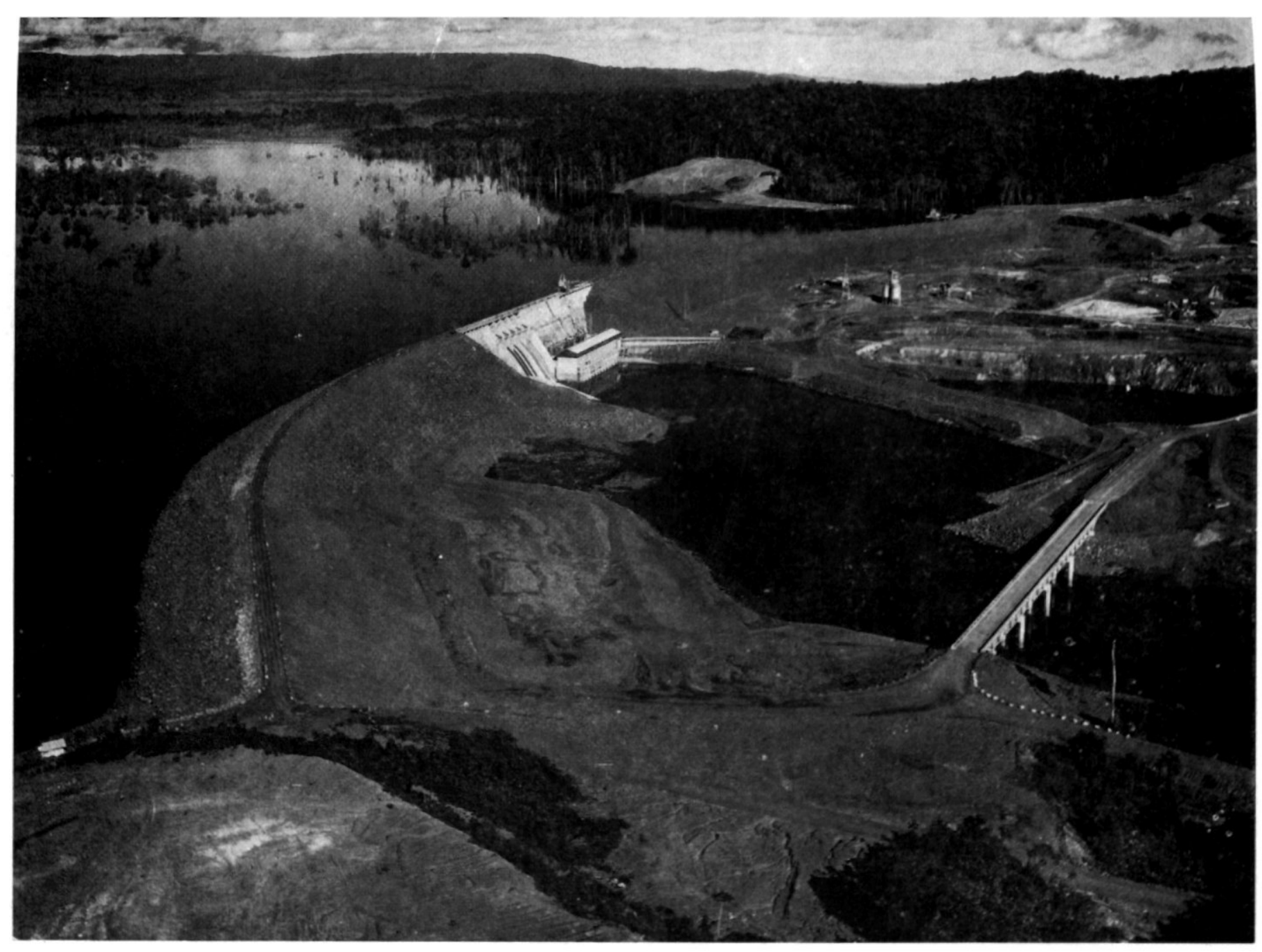

Plaat IX. Het Brokopondo-stuwmeer in wording, anderhalf jaar nadat de dam werd gesloten. [27 juni 1965] 


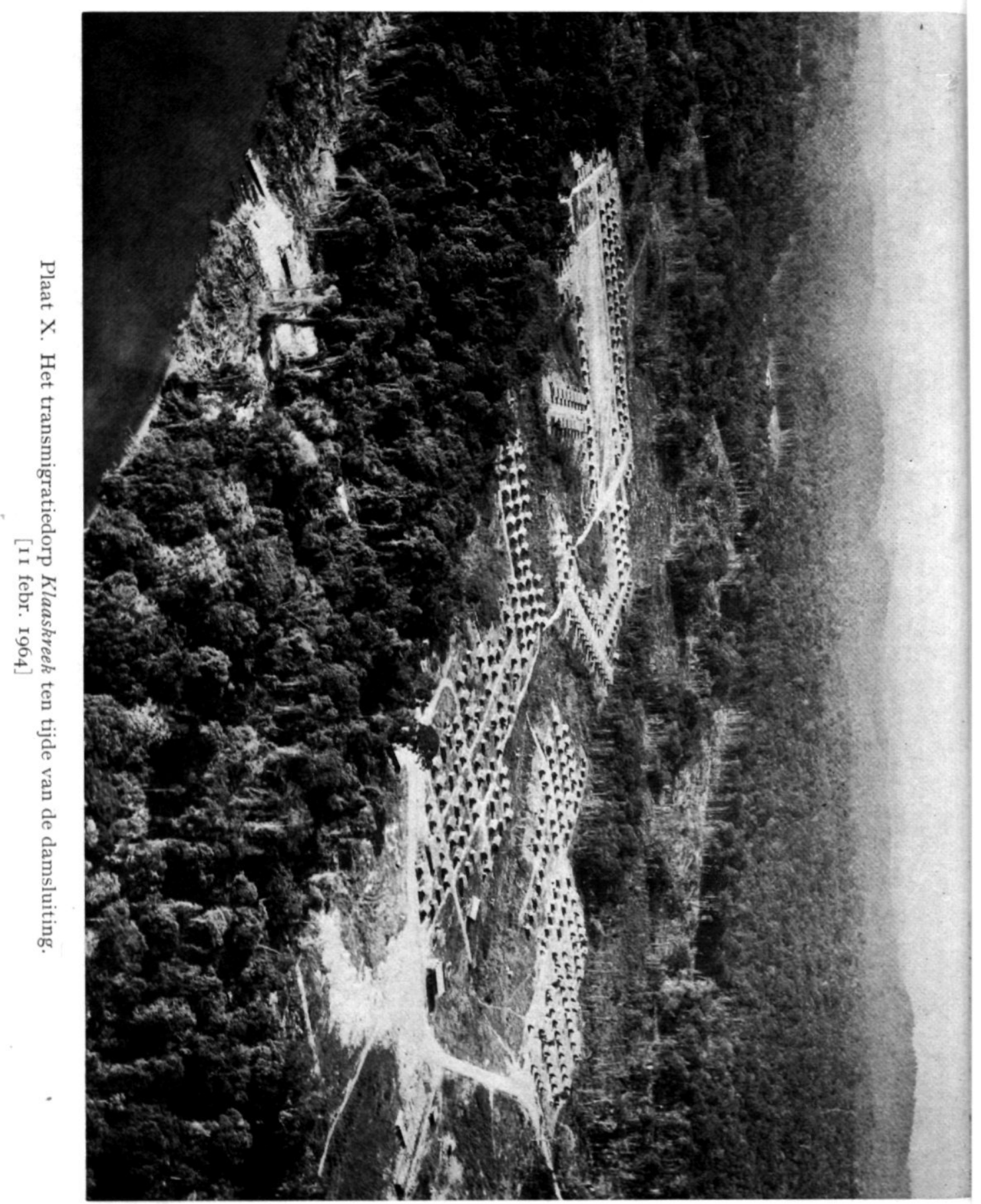




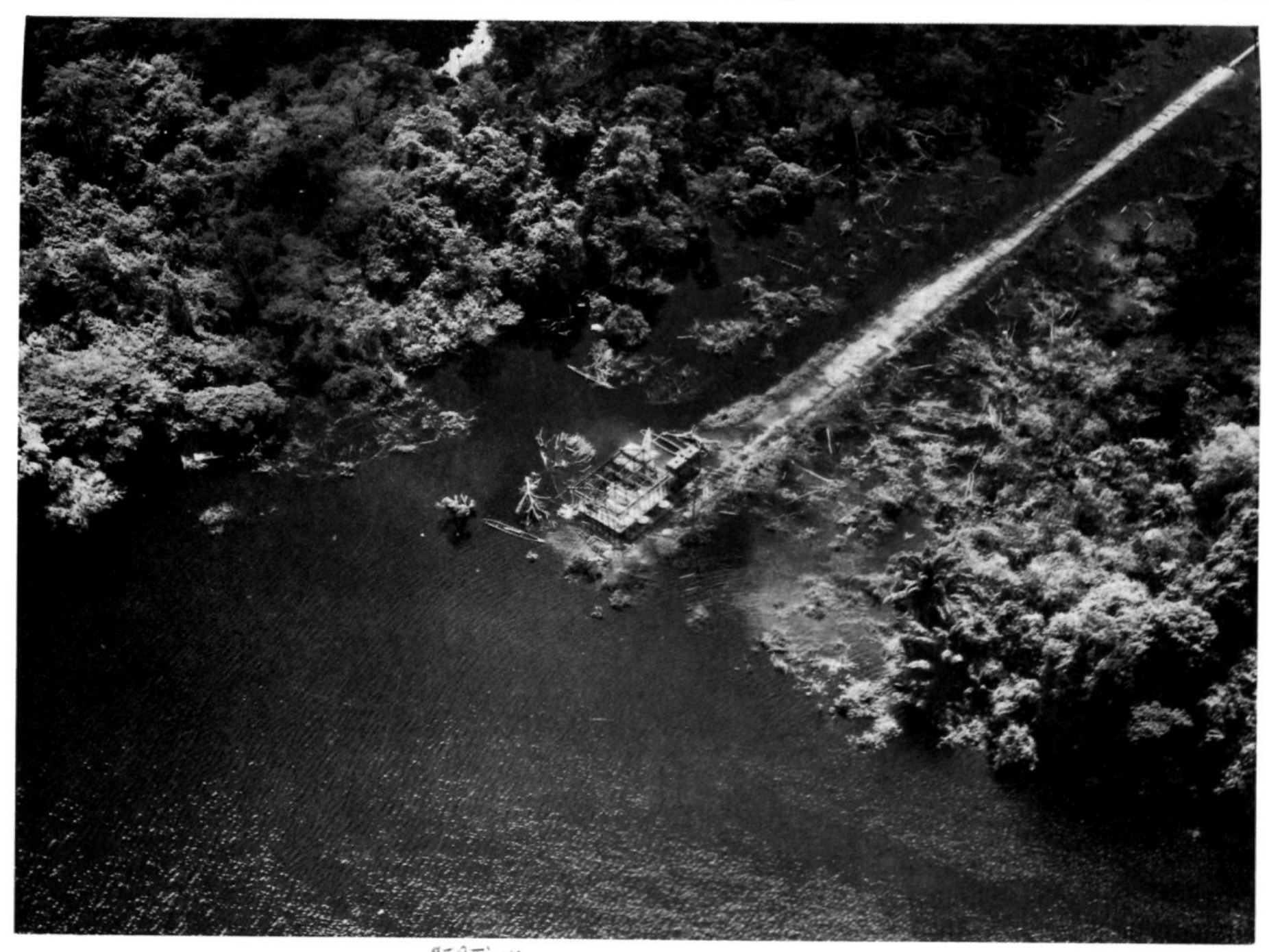

Plaat XI. Het hospital van Kabel, twee maanden na de afsluiting van de Surinamerivier. [29 april 1964] 


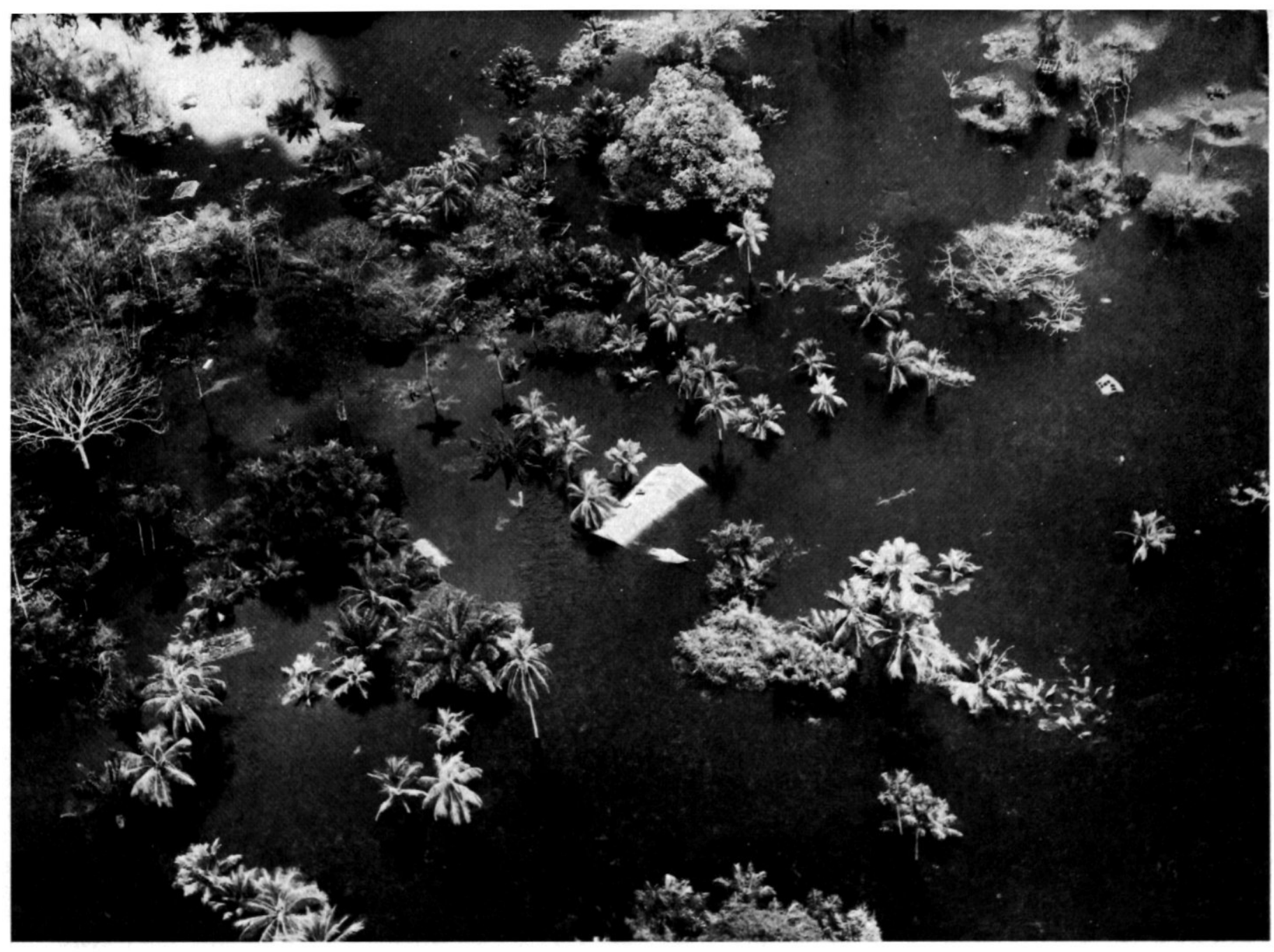

Plaat XII. Het rijzende water bij Koffiekamp, vijf maanden nadat de dam werd gesloten. [30 juni 1964] 


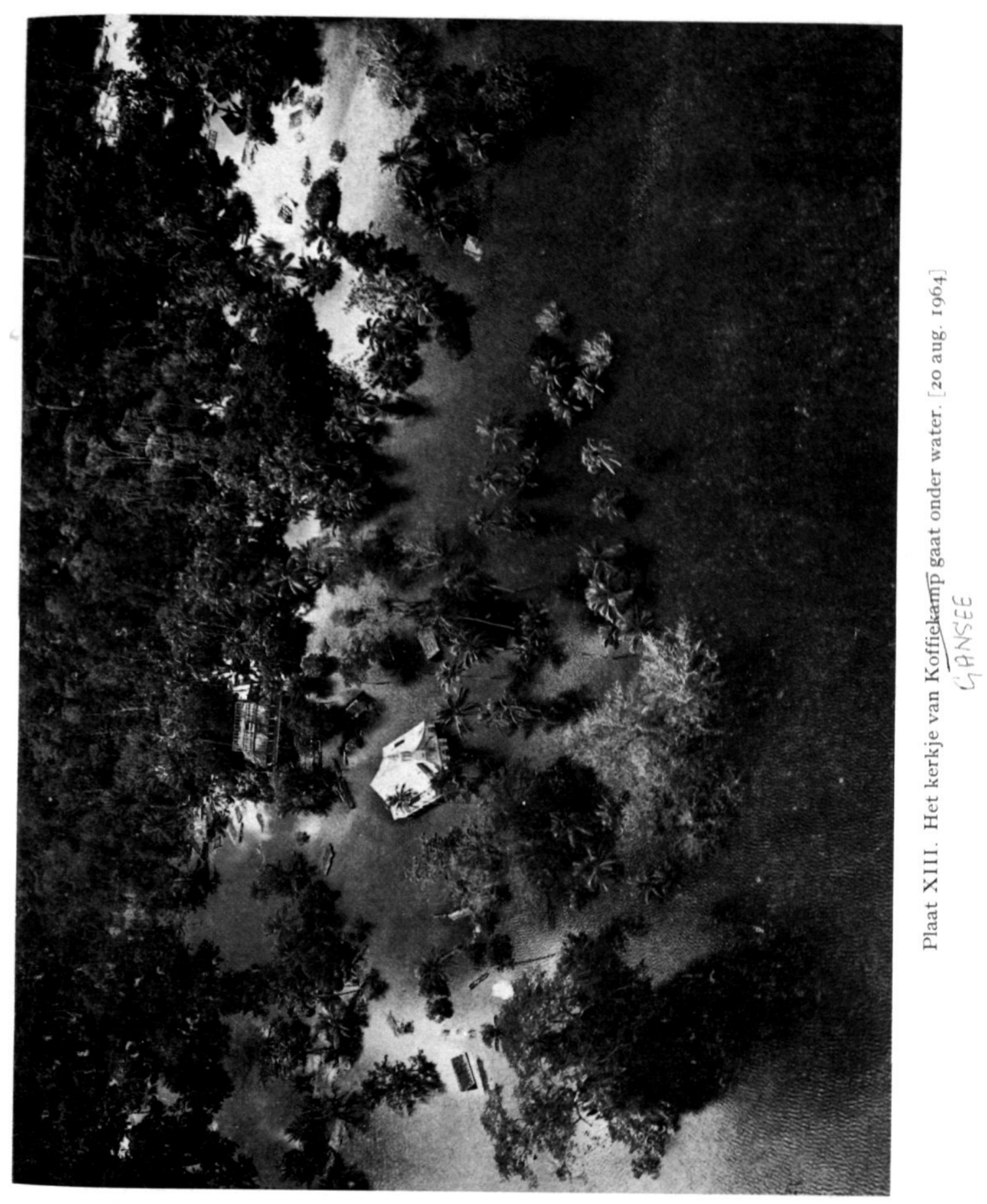




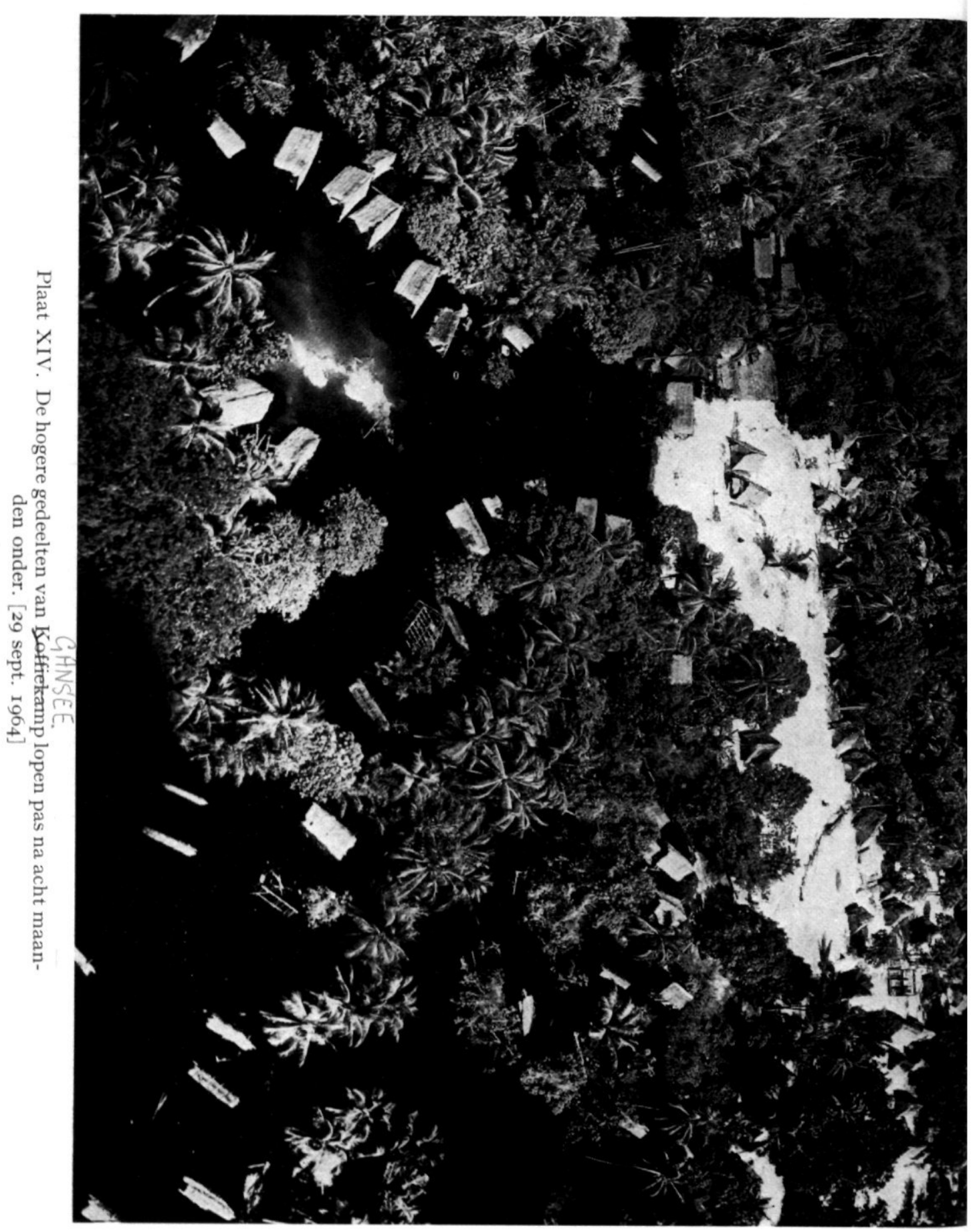




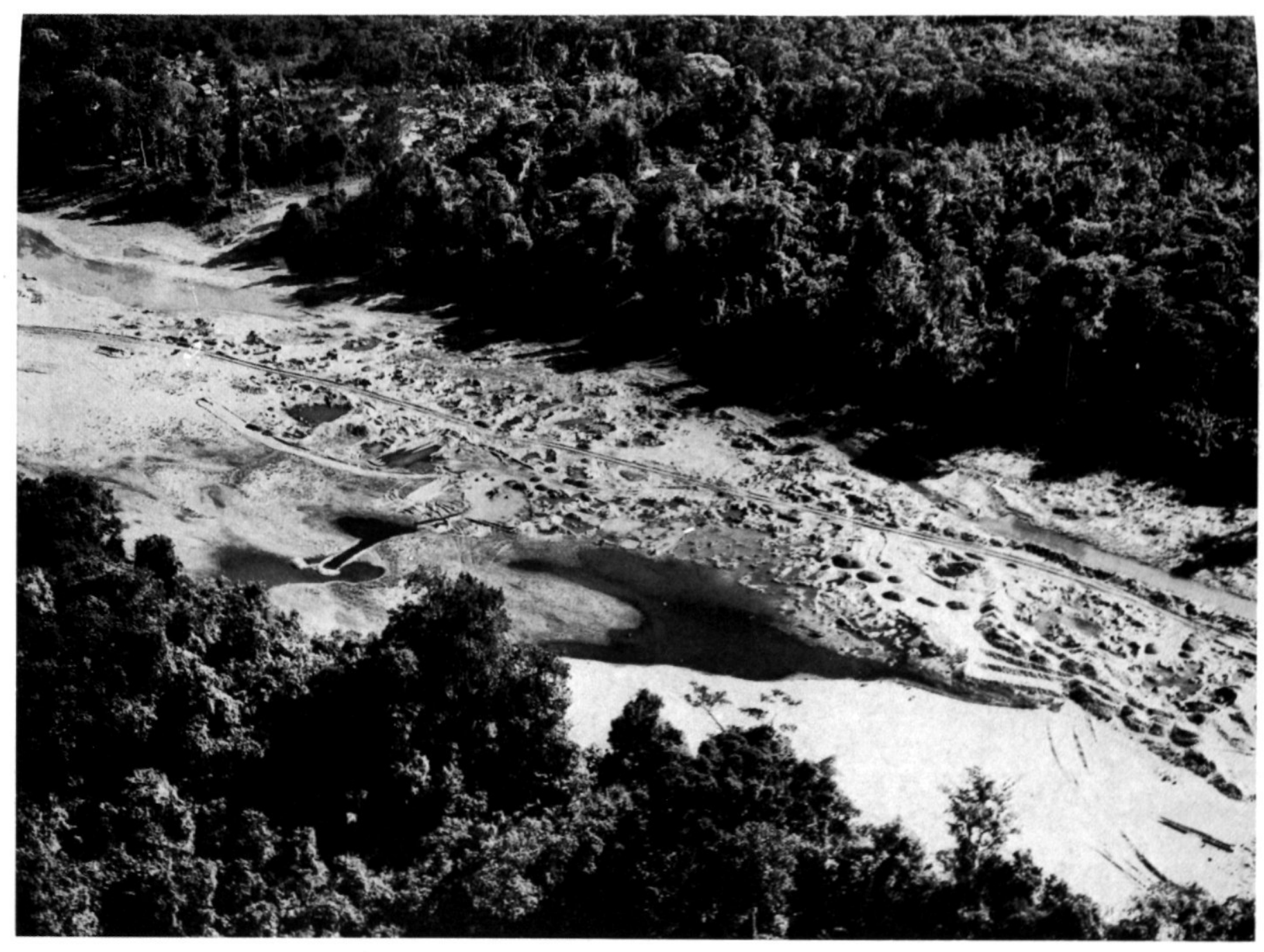

Plaat XV. Hoe de bedding van de Suriname-rivier er benedendams uitzag, tien maanden nadat de watertoevoer was afgesneden. [26 nov. 1964] 


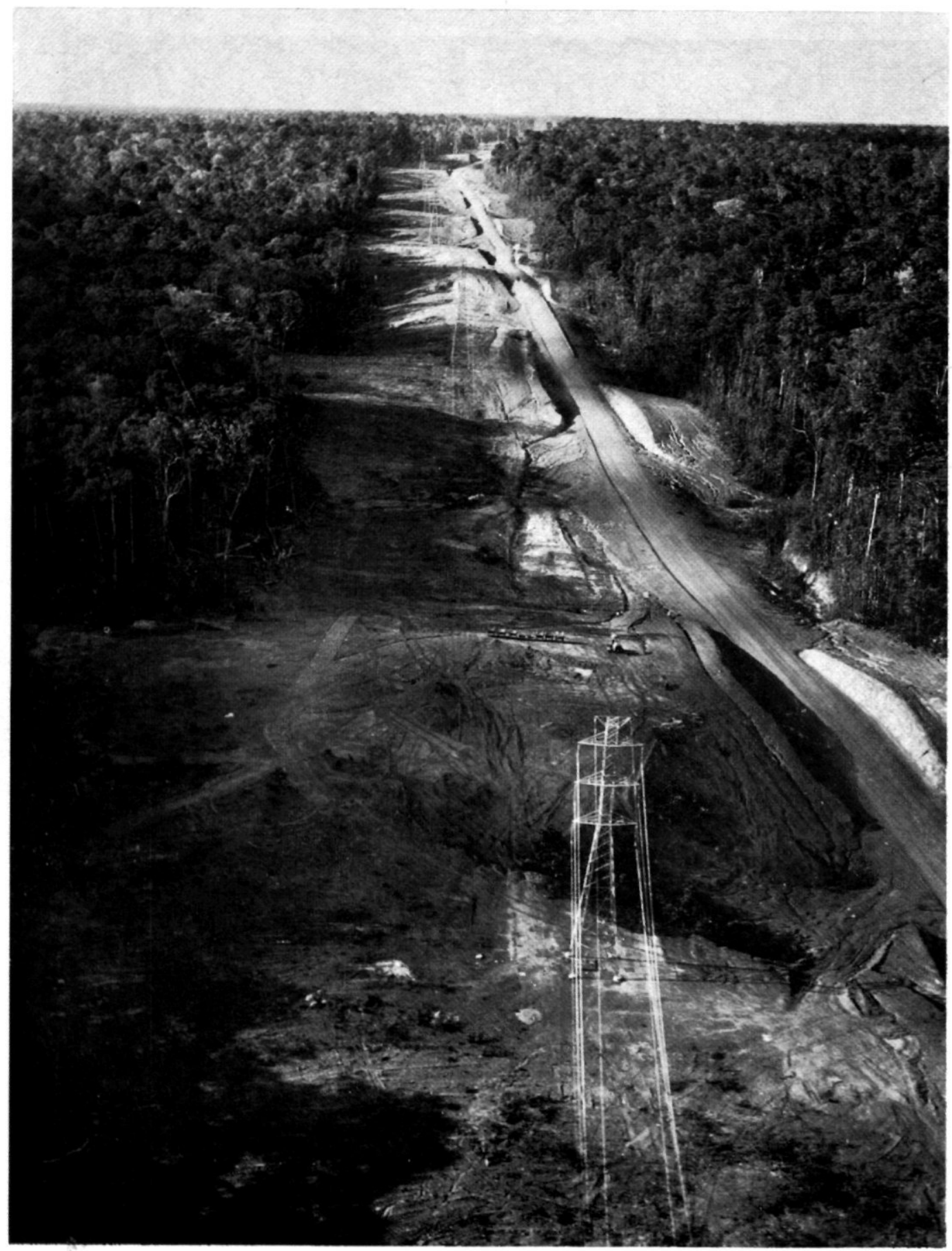

Plaat XVI. Weg van Paranam naar het Brokopondo-stuwmeer.

[3I okt. I964] 
zoeken aan het stuwmeer door Drs. P. LeentvaAR in de periode $\mathrm{I}$ april8 mei 1968 ( $\mathrm{N} f$ 7.500; 4 maart 1968) en door Dr. J. van DonselaAR in de periode I januari-6 maart 1969 (N $f$ I0.700; 12 december I968).

Het totale toegekende bedrag voor $1963-1969$ was $f$ 513.800; daarvan werd in werkelijkheid bijna $f$ 479. Ioo besteed.

De subsidieverlening voor I963 leidde tot velerlei activiteiten, overzee en in Nederland. De Wageningse hoogleraar Dr. J. DE WILDE, op bezoek in Suriname, had gelegenheid om op 9 en ro december 1962 in Afobaka en Paramaribo het onderzoekplan wetenschappelijk en zakelijk te bespreken met verschillende geinteresseerden; in zijn schriftelijk advies aan de Studiekring van Io december bepleitte hij de uitzending van een team van tenminste drie biologen. Dr. D. C. GEIJSKEs, toentertijd ambtenaar voor wetenschappelijk onderzoek bij het Ministerie van Binnenlandse Zaken, richtte zich met een schrijven van 3I december I 962 tot de Minister-President en het Ministerie van Algemene Zaken van Suriname, waarin hij aandrong op steun van Surinaamse zijde voor het onderzoek.

Inmiddels was in Utrecht door de Studiekring de BROKOPONDO Commissie Nederland opgericht, waarin zitting namen Prof. Ir. I. A. De Hulster, Prof. Dr. F. P. Jonker, Prof. Dr. J. Lanjouw (voorzitter), Dr. M. F. Mörzer Bruyns, Prof. Dr. P. H. van Thiel, Dr. P. Wagenaar Hummelinck en Dr. J. H. WesterMANN. Deze commissie nam de algemene wetenschappelijke leiding van het stuwmeeronderzoek op zich. Haar eerste bijeenkomst vond plaats op 30 november I 962 ; tot het einde van 1968 werd dertien maal vergaderd, meestentijds in het ZOöLOGISCH LABORATORIUM te Utrecht. In de vijfde vergadering, op 26 maart I964, werd de naam officieel omgedoopt tot CoMmissie NEDERLAND VOOR HET STUWMEERONDERZOEK IN SURINAME (Netherlands Commission for Research in Artificial Lakes in Surinam); 'Brokopondo Commissie' bleef echter als aanspreektitel gehandhaafd.

De Brokopondo Commissie werd op 20 augustus 1965 uitgebreid met de in Nederland teruggekeerde Dr. D. C. GeIJSKes en de Brokopondoonderzoekers Dr. M. Boeseman en Drs. P. LeentvaAr. Na hun repatriëring uit Suriname werden ook de andere onderzoekers er in opgenomen: Dr. G. F. Mees (15 augustus ig66), Dr. J. van DonselaAr en Drs. J. van DER Heide (3o maart 1967), en Drs. H. Nijssen en Drs. J. NijssenMeyer (22 februari 1968). Prof. Dr. P. H. van Thiel bedankte op 22 januari 1968 voor het lidmaatschap, na nog als emeritus-hoogleraar enige tijd lid te zijn gebleven. 
In de eerste helft van I963 werden de volgende academici bereid gevonden het onderzoek ter hand te nemen: Drs. P. LeEnTVaAR, hydrobioloog verbonden aan het RIJKSINSTITUUT VOOR VELDBIOLOGISCH ONDERZOEK TEN BEHOEVE VAN HET NATUURBEHOUd (RIVON) te Zeist ; Drs. J. VAN DER HEIDE, hydrobioloog verbonden aan het BOTANISCH LABORATORIUM VAN DE VRIJE UNIVERSITEIT, Amsterdam; Dr. M. Boeseman, ichthyoloog bij het Rijksmuseum van NatuUrlijke Historie, Leiden; Dr. J. van DonSElaAR, botanicus bij het InstituUt voor Systematische PlantKUNDE, Rijksuniversiteit te Utrecht.

Verscheidene werkbesprekingen werden met bovengenoemd team gehouden. Contact werd voorts gezocht met Dr. E. B. Worthington van de Nature Conservancy in Engeland, in verband met diens limnologische onderzoekservaring verkregen in Afrikaanse meren. Met hem werd in Utrecht op 7 augustus 1963 het onderzoeksprogramma besproken. Kort daarna zond hij enkele 'Notes on the Brokopondo Research Scheme', samengesteld door Dr. Rosemary McConnell née Low, die in Guyana visoecologisch onderzoek had gedaan.

Met hulp van Dr. C. F. A. BRuijning, die in juli-augustus I963 Suriname bezocht, en de directeur van het WOSUNA-Instituut te Paramaribo, de heer Jas D. Emanuels, alsmede diens tijdelijke vervangster Mevrouw W. J. Smit-Emanuels, werden voorbereidingen getroffen voor de lokale organisatie van het onderzoek, omvattende het verkrijgen van woon- en laboratoriumruimte, transportmiddelen te land en te water, apparatuur en hulpkrachten. Dank zij de grote medewerking van het DisTRICTSBESTUUR VAN BROKOPONDO en van SURALCo konden voor de gehuwde onderzoekers BoEseman en VAN DonselaAR en hun gezin woningen in Brokopondo worden verkregen, en voor de niet-gehuwde heren LEENTVAAR en VAN DER HEIDE een gemeubileerde kamer in een Suralco-barak te Afobaka. In die barak werd ook aan alle onderzoekers laboratoriumruimte met water en electriciteit, alsmede herbarium- en andere bergruimte ter beschikking gesteld.

De heer LeentVAaR was de eerste die in Suriname arriveerde, op 3 november I963; hij reisde op II november door naar Afobaka. Dr. Boeseman, Mevrouw E. M. G. Boeseman-Pluymert en twee kinderen kwamen 13 november aan en vonden daarop, zoals vermeld, huisvesting in Brokopondo. Op 23 december arriveerden Dr. van Donselaar, Mevrouw Dr. W. A. E. van Donselaar-Ten BoKkel HuInINK (botanica) en twee kinderen; ook zij betrokken een woning in Brokopondo. Als laatste van het eerste onderzoek- 
team kwam Drs. vaN DER HeIDE, op I februari I964; hij vond, evenals Drs. LeentvaAR, onderdak in Afobaka.

Dr. D. C. GeijSkEs, toentertijd Directeur van het Surinaams Museum, stelde zich op 7 februari 1964 beschikbaar als rapporteur-coördinator van de periodiek uit te brengen deelnemersrapporten. Een gezamenlijke bespreking tussen hem en de teamgenoten vond plaats op 3 maart in het WOSUNA-Instituut, in tegenwoordigheid van Dr. P. WAGENAAR HuMmelincK; eerder, op 2527 februari, had laatstgenoemde een en ander besproken met de teamleden, bij zijn bezoek aan Afobaka en Brokopondo. In de vergadering van 3 maart werd de grondslag gelegd voor de termijnrapportering (Progress Reports). Op 3I maart volgde, ook weer in het WOSUNA-Instituut, de eerste bespreking tussen Dr. GEIJSKES en de teamgenoten over de rapporten zelf. Na het vertrek van Dr. GeIJSkes uit Suriname, op 2 mei I965, is door de teamleden de rapportering zonder coördinator verzorgd.

In de jaren 1964 tot en met 1969 zijn de volgende Progress Reports van het Biological Brokopondo Research Project, Surinam, verschenen, uitgegeven door de Foundation for Scientific Research in Surinam and the Netherlands Antilles:

Part I, I963-1964, p. I- 89

Part II, 1965, p. 90-14I

Part III, 1965-1966, p. 142-207

Part IV, 1967-1969, p. 208-265.

Deze omvatten de in de Engelse taal gestelde, gestencilde periodieke verslagen over de hydrobiologische, botanische, en ichthyologische en andere werkzaamheden, geïllustreerd met gedrukte kaarten en grafieken. Aan het einde van elk rapport is een mailing list opgenomen.

Naast de verslagen voor de Progress Reports werden door de onderzoekers verschillende artikelen gepubliceerd, welker titels zijn opgenomen in de bibliografie.

Het eerste team was slechts acht maanden tezamen werkzaam. Drs. LeENTVAAR verliet Suriname op 29 september I964, zodat van die datum af het hydrobiologisch werk door één onderzoeker, Drs. van DER HeIDE, werd gedaan. Dr. Boeseman sloot kort daarna, op 4 oktober, het ichthyologisch en ander zoölogisch veldwerk af. Dr. G. F. MEes, ichthyoloog en ornitholoog van het Rijksmuseum van Natuurlijke Historie, Leiden, vergezeld door Mevrouw V. J. Mees-Balchin, maakte begin maart ig65 een vervolg met het vissenonderzoek en het bijeenbrengen van ander zoölogisch materiaal, tot april I966. Daarna, van I8 april 1966 tot 30 juni 1967 , nam de ichthyoloog Drs. H. NiJSSEN van het ZoöLOGISCH MuSEum, Universiteit van Amsterdam, het vissen- 
onderzoek over; evenals de heren BoEsEMAN en MeEs maakte ook hij andere zoölogische collecties.

Dr. van DonselaAR werd bij zijn veldwerk onafgebroken bijgestaan door de Surinaamse boomkenner E. M. C. HeLstone, gepensioneerd bij de Dienst 's Lands Bosbeheer, en incidenteel door Mevrouw Dr. W. A. E. van DonselaAR-ten Bokkel Huinink. Op 7 september I964 stelden hij en Mevrouw van DonselaAR de Studiekring voor dat ook laatstgenoemde, zij het in beperkte mate, formeel aan het onderzoek zou deelnemen en wel voor het determineren van de verzamelde planten en voor een onderzoek van de plantengroei in de drooggevallen rivierbedding beneden de stuwdam. Het verzoek van de Studiekring om daarvoor gelden in het Brokopondo-subsidie op te nemen, kon door WOTRO niet worden ingewilligd.

Van belang voor het botanisch onderzoek was het, op verzoek van Dr. van DONSELAAR en WOTRO uitgevaardigde Besluit van 7 november I 666 van het toen onder leiding van Minister J. RENS staande Departement van Opbouw (Bureau no. I972, no. D I807) betreffende het ter beschikking stellen voor wetenschappelijk werk van een terrein van I20o hectare, gelegen ten oosten van de spoorbaan in het Distrikt Brokopondo, zoals aangeduid op de kaart van de landmeter S. O. EsaJAS van 28 april I966. In dit aan de noordwestelijke rand van het stuwmeer gesitueerde gebied zijn proefterreinen voor het successie-onderzoek uitgezet. De DIENST 's LANDS BosBeneER heeft het gebied met borden gemarkeerd. Controle op het kapverbod werd door de Districtscommissaris van Brokopondo toegezegd.

Met het vertrek van Dr. van DonselaAR en zijn familie uit Suriname, op I9 december I966, werd het continue botanische onderzoek beëindigd. Door hem en Drs. vAN DER HEIDE werden, tijdens een afscheidsbijeenkomst ten paleize van Gouverneur Mr. H. L. DE VRIES op I4 november, causerieën over het onderzoek gehouden. In deze paragraaf kan tevens vermeld worden dat de beide onderzoekers veel eerder, namelijk op 9 oktober 1965 , bij een bezoek van Koningin Juliana en PRINS BERnhard aan het stuwmeer voor het vorstelijk paar een korte voordracht hielden. Ook bij andere gelegenheden werden door Dr. van DonselaAR en de andere onderzoekers lezingen gehouden over het onderzoek, o.a. voor de personeelsvereniging van Suralco. In de lokale pers verschenen enkele artikelen.

Voor het hydrobiologisch onderzoek van Drs. vAN DER HEIDE werd hulp ontvangen van het CENTRAal LABORATORIUM van het 
Departement van Volksgezondheid in Suriname; dit Laboratorium was in 1965 bereid chemische wateranalyses uit te voeren. Toen echter bleek dat een groter aantal analyses benodigd was dan het Laboratorium kon leveren, werd besloten om eind november 1965 ten laste van de WOTRO-financiering de leerling-analist HARRO Wong Fong SANG aan te stellen voor het nemen van watermonsters en voor eenvoudige fysisch-chemische bepalingen in het laboratorium te Afobaka; hij werd ook belast met het nemen en conserveren van planktonmonsters.

Drs. vAN DER HEIDE beëindigde het veldwerk medio november I 966 en vertrok de 30 ste van die maand uit Suriname. Officieel op 25 november 1966 maar practisch gesproken op I januari 1967 werd het hydrobiologisch onderzoek voortgezet door Mevrouw Drs. J. Nijssen-Meyer, tot 30 juni 1967.

Ondertussen was door de Studiekring besloten dat het continue Brokopondo-onderzoek op 30 juni 1967 zou worden afgesloten en dat daarna alleen periodieke series waarnemingen door van tijd tot tijd uit te zenden deskundigen zouden worden gedaan. Door Dr. J. H. WestermanN, die op I9 maart 1967 het stuwmeer in gezelschap van de heer en mevrouw NiJssEN bezocht, werden over deze afsluiting besprekingen gevoerd met genoemde twee onderzoekers, de vertegenwoordiger van WOTRO en met Suralco. De familie NiJSSEN heeft vóór haar vertrek op 30 juni 1967 veel hulp verleend bij de liquidatie en de daarmee verbonden inventarisatie.

De in I963 van Suralco in gebruik gekregen woon- en laboratoriumbarak te Afobaka werd ontruimd en naar elders verplaatst. Korjalen, buitenboordmotoren en auto's werden geschonken aan Surinaamse Diensten of verkocht. De apparatuur werd verdeeld over de WATERLOOPKUNDIge AFDELING ${ }^{1}$ en WOTRO-Paramaribo, en voor een deel naar Nederland gezonden. Chemicaliën werden overgedragen aan de Waterloopkundige Afdeling en het Centraal Laboratorium. Literatuur werd opgeborgen in de WOTRO-bibliotheek te Paramaribo.

Voor de leerling-analist HARRo Wong Fong SANG kon een plaats worden gevonden bij het Landbouwproefstation, terwijl

1 De Waterloopkundige Afdeling van het Ministerie van Openbare Werken en Verkeer. Dit Ministerie werd medio 1967 omgedoopt in Ministerie van Bouwwerken, Verkeer en Waterstaat, en bij Landsbesluit van 27 januari I970 in Ministerie van Openbare Werken. 
enkele hulpkrachten bij de Waterloopkundige Afdeling werden aangesteld.

De monsterpunten in het meer werden door Mevrouw NiJssen op hardhoutstammen gemerkt, met rode verf op een hoogte van 233-234 voet.

De Afdeling Bacteriologie van het Centraal Laboratorium werd bereid gevonden $\mathrm{Cl}^{\prime}$ bepalingen te doen maar geen volledige wateranalyses. De WATERLOOPKUNDIGE AfDeling zegde toe de hydrobiologische bemonsteringen op vijf regenstations en op zeven diepten voort te zetten, eenmaal per maand, en van de monsters alle gebruikelijke fysische bepalingen te doen; ook zouden planktonmonsters worden gefixeerd. Gegevens en planktonmonsters werden daarna van tijd tot tijd naar Nederland gezonden voor bewerking. Door deze Afdeling werd ook steun toegezegd voor periodiek in Suriname terug te keren onderzoekers.

Mevrouw NiJSSEN bewerkte na terugkeer in Nederland de door haar verzamelde gegevens en monsters in het RIVON te Zeist en later in het Rijksmuseum van Natuurlijke Historie, Leiden.

Conform het door de Brokopondo Commissie vastgestelde beleid werden sedert het onderbreken van het continue onderzoek enkele korte series waarnemingen en bemonsteringen uitgevoerd. Van I april tot 8 mei I 968 bezocht Drs. LeEnTvaAR opnieuw Suriname en het stuwmeer; hij nam watermonsters bij de gemerkte punten voor fysische en chemische bepalingen en voor determinatie van het plankton. In overleg met de Waterloopkundige Afdeling werd een nieuw maandelijks schema van bemonstering vastgesteld, in verband met de gewijzigde omstandigheden in het stuwmeer. Dr. J. van DonselaAR inspekteerde van 7 januari tot 5 maart 1969 de indertijd door hem uitgezette botanische proefterreinen aan de noordwestelijke rand van het meer en deed ook andere waarnemingen; hij werd wederom bijgestaan door de boomkenner Helstone. Bij deze bezoeken werd veel medewerking ontvangen van de Districtscommissaris van Brokopondo, Suralco en de Waterloopkundige Afdeling.

Het onderzoek van het Brokopondo-team was niet beperkt tot het stuwmeer en het overige stroomgebied van de Suriname-rivier. Het werd namelijk gewenst geacht, mede van de zijde van de Brokopondo Commissie, om ook in andere rivieren en wateren gegevens en materiaal te verzamelen; kennis daarvan is immers belangrijk voor het Brokopondo-onderzoek én voor de exploratie van eventueel elders te scheppen stuwmeren. Dit 'buit en-onder- 
zoek' kon zonder moeite ingepast worden in het tijdschema.

In januari 1964 bezocht P. LeentvaAR de Tibiti, in maart, samen met J. vAN DER HEIDE, de Tapanahony bij de monding van de Paloemeu en, met M. Boeseman, de Saramacca (eerste helft van april). Op 5 en 6 september nam hij, met vaN DER HEIDE enkele monsters in de Beneden-Marowijne, de Cottica en de Commewijne. Tijdens de terugreis naar Nederland verrichtte hij enkele hydrobiologische waarnemingen in het Gatún-meer, Panamá (2 oktober I964).

M. Boeseman verzamelde in de eerste helft van april I964 vissen in de Saramacca en bezocht van 8 tot 17 september van dat jaar het eiland Trinidad, eveneens voor ichthyologisch onderzoek.

In september I 965 bezocht J. vAN DER HEIDE, samen met G. F. MEEs, de Kabalebo-rivier.

J. van DonselaAR verrichtte, op verzoek van de Dienst 's Lands Bosbeheer, op 2 en 3 november 1964 enig onderzoek in de savannen van Blaka Watra, nam in de eerste helft van februari r 965 deel aan een onderzoek van het natuurreservaat VoltzbergRaleighvallen, en deed in augustus r 965 en februari en juli 1966 korte vegetatiekundige successie-opnamen in een door brand ontstane zwamp aan de Boven-Perika. Ook maakte hij voor deze Dienst een tocht naar de Sipaliwini-savanna, van 20 augustus tot 9 september 1966 , in verband met plannen om aldaar een natuurreservaat te stichten. Hij en VAN DER HEIDE namen deel aan het 6-ıo juni I966 te Belém, Pará, Brazilië, gehouden Symposio sôbre a Biota Amazonica (Symposium on the Biota of the Amazon Basin), georganiseerd door The Association for Tropical Biology, New York, met medewerking van de Brazilian National Research Council.

G. F. MeEs bezocht in september 1965, gedurende tien dagen vergezeld door vaN DER HEIDE, de Beneden-Kabalebo; het BUREAU VOOR WATERKRACHTWERKEN verleende daarbij medewerking. Van 16 november tot 3 december van dat jaar deed hij onderzoekingen in de Tapanahony bij de monding van de Paloemeu, en medio januari 1966 in de Matapica, geholpen door de DiEnsT Visserijen. In de Sipaliwini-savanna verzamelde Mees tussen eind januari en $2 \mathrm{I}$ februari r 966 vooral vissen en vogels.

H. NiJSSEN bezocht met Dr. W. VERVOORT, Rijksmuseum van Natuurlijke Historie te Leiden, in juni I966 de Beneden-Marowijne, Beneden-Saramacca en Beneden-Coppename. In februari I967 onderzocht hij de Kleine Saramacca, begin april met zijn echtgenote het toekomstige stuwmeergebied Stondansi aan de 
Boven-Nickerie (met medewerking van de Waterloopkundige Afdeling), in de tweede helft van april de Boven-Marowijne, Lawa en Tapanahony (daarbij geholpen door de Dienst Visserijen), en in mei 1967 de Boven-Coppename (met medewerking van de GEOLogisch Mijnbouwkundige Dienst).

In de Brokopondo Commissie is meermalen gesproken over de wenselijkheid om het biologisch onderzoek aan te vullen met verdampingsonderzoek in en bij het stuwmeer, tot het verkrijgen van een beter begrip van de waterbalans en de invloed daarop van de geinundeerde en drijvende vegetatie. Tijdens het verblijf in Suriname van het Commissie-lid J. H. Westermann (februarimaart I967) werden door hem oriënterende besprekingen over zulk onderzoek gevoerd met vertegenwoordigers van het Bureau voor Waterkrachtwerken en vooral de ter zake geinteresseerde Waterloopkundige Afdeling. Door de Studiekring werd daarop contact opgenomen met de fysicus-meteoroloog Drs. W. J. DERKSEN van de Afdeling voor NatuUr- en WeErkunde van DE LANDBOUWHOGESCHOOL te Wageningen. Een door laatstgenoemde op 30 juni 1967 aangeboden voorlopig onderzoekprogramma bleek te kostbaar om te worden uitgevoerd.

In I967 reeds werden door de Waterloopkundige Afdeling metingen verricht van verdamping van het vrije wateroppervlak en van neerslag in het stuwmeer. Begin I968 vervolgde deze Afdeling dit onderzoek samen met het Ministerie van Landbouw, Veeteelt en Visserij; met hulp van bij het Ministerie stage-lopende Wageningse studenten werd op het stuwmeer geëxperimenteerd met verschillende drijvende stellages met verdampingsbakken. De experimenten waren echter te weinig gericht en te ondoelmatig, zodat geen betrouwbare gegevens werden verkregen.

Onder leiding van Ir. G. E. KAMERLING en R. van DeR WeERT van het LANDBOUWPROEFSTATION werden echter begin juni 1968 betere verdampingsexperimenten begonnen in de Cultuurtuin, en in oktober van dat jaar op het stuwmeer, met drijvende bakken in verschillende opstellingen; daarbij werden ook neerslag, temperatuur, dampspanning, windsnelheid en zonneschijn gemeten. De verdamping werd gemeten in bakken met open water alsmede in bakken met waterhyacinth en met een drijvende grassoort (evapotranspiratie). In tegenstelling tot de door Timmer \& WeLDON ('Evapotranspiration and pollution of water by water hyacinth', Hyacinth Control Journal 6, June 1967) in Florida gevonden waarden van evapotranspiratie van waterhyacinth - die ge- 
middeld 3,7 maal zo hoog waren als de verdamping van een open wateroppervlak - bleken de metingen in de Cultuurtuin en op het stuwmeer tot veel lagere gemiddelden te leiden. De in de droge periode oktober tot en met december 1968 in het stuwmeer gevonden verhouding tussen de potentiële evapotranspiratie van waterhyacinth en de verdamping van open water was gemiddeld slechts I,4 : I (zie VAN DER WEERT \& KAMERLING I968). ${ }^{1}$

Reeds veel eerder was Suralco - bevreesd voor grote verliezen aan water, en dus waterkracht, vanwege de toentertijd zeer hoog bevonden waterhyacinth-evapotranspiratie - overgegaan tot intensieve en kostbare bestrijding van genoemde waterplant. In oktober 1964 (acht maanden nadat het stuwmeer zich was beginnen te vormen) begon Suralco practische aandacht te besteden aan de waterhyacinth (Eichhornia crassipes), nadat de bedrijfsarts TJON TJIN JoE te Afobaka sedert juli enkele experimenten met chemische bestrijdingsmiddelen had gedaan en nadat de situatie op 3I augustus was besproken door Dr. van DonselaAR en Alcoaen Suralco-functionarissen, onder overlegging van door vaN DONSELAAR verzamelde gegevens. Advies werd ingewonnen van Dr. L. W. Weldon van het-U.S. Department of Agriculture, Fort Lauderdale, Florida (eind oktober). Aanvankelijk werd een bestrijdingsploeg ingezet die bespuitingen uitvoerde uit één boot; als bestrijdingsmiddel werd een $\mathrm{I} \%$ oplossing van het herbicide 2,4-D (Dow Chemical) gebruikt, terwijl bestrijding ook geschiedde door de planten uit het water te vissen. Later werden meer boten ingezet met een betere outillage voor het spuiten, opererende uit verschillende kampen (Bauxco Nieuws, april r965).

Sedert oktober 1965 werd zowel door boten als, periodiek, uit een vliegtuig gespoten respectievelijk verneveld, met 2,4-D in hogere concentratie, een en ander met redelijk goede resultaten. Op I8 september 1966 begon een langdurige en effectieve vliegtuigbestrijdingscampagne (van DonselaAR I968). Dr. Weldon stelde van DONSELAAR tweemaal in staat het gebied uit een vliegtuig in ogenschouw te nemen.

( De kosten van de bovengenoemde bestrijdingswijzen waren echter hoog; jaarlijks ging het om een half tot één millioen Surinaamse guldens. In het bijzonder na het bekend worden van de gegevens verkregen door VAN DER WEERT \& KAMERLING (I968),

1 Interessant in dit verband is H. MADEc's artikel 'L'évapotranspiration potentielle et le bilan de l'eau en Guyane' (Monogr. Mét. nat. no. 39, 1965). 
waaruit bleek dat de evapotranspiratie veel lager was dan die welke in Florida was gevonden, werd een belangrijk punt van overweging bij Suralco of de bestrijding wel, en in dezelfde mate, zou moeten worden voortgezet. De kosten van verdere bespuitingen zouden wel eens hoger kunnen zijn dan de kosten van verlies aan water door evapotranspiratie wanneer geen bestrijding zou plaatsvinden. In Suriname. Feiten en Cijfers (van januari 1970) is vermeld dat in 1969 zo goed als alle waterhyacinth is uitgeroeid en dat de bestrijding voorlopig kan worden opgeschort. In februari 1970 besloot Suralco de bespuiting uit een vliegtuig voor minstens een jaar te staken; bestrijding uit boten, opererend uit twee kampen, werd, waar nodig, voortgezet. 1

Als gevolg van bovengenoemde overwegingen inzake de effectiviteit en rentabiliteit van de chemische bestrijding wendde in juni 1968 Suralco zich via Dr. Ir. J. RUINARD, de WOTRO-vertegenwoordiger, tot de Studiekring met het verzoek te willen nagaan of een bestrijding door in het stuwmeer uit te zetten zeekoeien (Trichechus m. manatus) zinvol zou zijn. De Brokopondo Commissie heeft ten aanzien van deze suggestie, om verschillende redenen, negatief geadviseerd (zie ook NoELMANS I969).

Meer belovend lijkt biologische bestrijding van de waterhyacinth met insecten en mijten. Daarover werd van I 9 tot 28 februari 1968 onderzoek gedaan door F. D. BENNETT \& H. ZwöLFER (I968) in de omgeving van Paramaribo, Brokopondo-meer, Nickerie en Coesewijne. Al eerder waren hierover in het meer waarnemingen gedaan door Dr. L. W. WELDON (september I965) en Dr. J. van DonselaAR (oktober I965); door laatstgenoemde verzamelde keverlarven en -poppen werden door Dr. W. H. ANDERSON, Agricultural Research Service, Washington D.C., gedetermineerd.

Vermelding verdient voorts de in I 968 en I 969 door J. W. GoNGGRYP gedane suggestie om zo mogelijk de Surinaamse zoetwaterpaalworm (Psiloteredo healdi) in het meer uit te zetten, in de verwachting dat geinundeerde en afgestorven bomen door deze paalworm zullen worden aangetast en vernietigd. Hardhoutstammen, zoals basralocus, zullen echter daartegen bestand zijn.

1 Een belangwekkend artikel over 'Aquatic weeds', met de veelzeggende ondertitel "The rampant quality of aquatic weeds has become one of the symptoms of our failure to manage our resources", verscheen van de hand van L. G. Holm, L. W. WeLdon \& R. D. BLAcKBURN in Science (7 november 1969). Ook Brokopondo is daarin genoemd. 
4.

BIBLIOGRAFIE

a.

TECHNISCHE EN ECONOMISCHE ASPECTEN

(in chronologische volgorde)

Eysvoogel, W. F., 1950. Mogelijkheden tot benutting van de rivierdebieten in Suriname voor de opwekking van electrische energie. Nota.

Blommestein, W. J. van, 1950 (Aug.). Een Combinatie-plan voor de Suriname-rivier. Coördinatie College Suriname. Economisch-financiële sector. Paramaribo, ro pp., I bijl., 2 fig., stencil.

Eysvoogel, W. F., I95I (Juli). Nota over het vraagstuk van de energievoorziening.

Eysvoogel, W. F., 195I (Dec.). Witte steenkool in Suriname. Doel en strekking van het 'plan-Blommestein'. Oost en West 44, Suriname nummer I2, P. II-I4.

Stichting Planbureau Suriname, 1951. The Brokopondo Project. Stencil.

International Bank for Reconstruction and Development, 1952 (May). Report of a Mission organized by the International Bank for Reconstruction and Development, with Recommendations for a Ten Year Development Program for Surinam. The Johns Hopkins Press, Baltimore, 27I pp. Technical Appendix No. 4. The Brokopondo Project, p. 204-213 (Technische Bijlage No. 4. Het Brokopondoplan 4. 1-5).

Stichting Planbureau Suriname, 1952 (Juni). De grondslagen van een Tienjarenplan voor Suriname. Paramaribo-Den Haag, 191 pp., 3 kaarten, stencil (p. 108-113: Het Brokopondoplan).

N.V. Billiton Maatschappij, 1952 (Nov.). Beschouwingen omtrent het Combinatieplan Surinamerivier, tevens samenhangende met een aluminium-industrie in Suriname. 's-Gravenhage, 75 pp. incl. kaarten, fig., tabellen, stencil.

Société Anonyme des Grands Travaux de Marseille, 1952 (Dec.). Rapport Mission préliminaire. Note complémentaire. [Jan. 1953]. 
Internationale Bank voor Herstel en Ontwikkeling, Washington D.C., 1952. Suriname, aanbevelingen voor een Tienjarenplan. Rapport vertaald in opdracht van de Stichting Planbureau Suriname, stencil.

Stichting Planbureau Suriname, L. van GEUNS, 1952. Het Brokopondoplan, radiocauserie.

Ringma, S. H., I953 (Jan.). Combinatieplan Suriname rivier (Brokopondoplan). Hydrologische Nota No. 5. Eindverslag afvoerjaar 1952. Stichting Planbureau Suriname, Paramaribo, 62 pp., 26 bijlagen, stencil.

Ringma, S. H., 1953. Combinatieplan Suriname rivier. Hydrologische Nota No. 6. Verslag Iste kwartaal afvoerjaar I953. Beschouwingen over de verdeling van de regenval m.b.t. het maken van aarden dammen. Hoorn, 8 pp., 7 bijlagen, getypt.

Stichting Planbureau Suriname, 1953. Verslag van de werkzaamheden met betrekking tot het vooronderzoek van het Brokopondoplan tot ultimo 1951. Bijlage A bij Jaarverslag I95I, p. I4-17, stencil.

Stichting Planbureau Suriname, L. van Geuns, 1953. Overzicht van de werkzaamheden betreffende het vooronderzoek Brokopondoplan alsmede van de tot op I november 1952 verkregen resultaten. Bijlage A bij Jaarverslag 1952 , p. 40-6o, stencil.

Stichting Planbureau Suriname, 1953 (Feb.). Memorandum inzake Combinatieplan Suriname rivier. Stencil.

Geuns. L. van, 1953 (Feb.). De stuwdam Brokopondo in Suriname. Schakels 63 (Kabinet Vice-Minister-President, 's-Gravenhage), p. 8-13, stencil.

GeUnS, L. van, 1953. Nota van I7 maart (Samenvatting van kritische beschouwingen over N.V. Billiton Maatschappij's 'Beschouwingen omtrent het Combinatieplan Surinamerivier' 1952).

Stichting Planbureau Suriname, 1953 (April). Beoordeling van het door de N.V. Billiton Maatschappij ingediende rapport, getiteld 'Beschouwingen omtrent het Combinatieplan Surinamerivier'. Stencil.

Stichting Planbureau Suriname, 1953 (April). Beknopt overzicht van het Rapport betreffende het Combinatieplan Surinamerivier, uitgebracht door de Société des Grands Travaux de Marseille. Stencil.

EysvoogeL, W. F., I953 (Juli). Enige opmerkingen over de te bouwen dam in de Suriname-rivier nabij Sara. Wageningen, 2 pp., getypt.

Stichting Planbureau Suriname, 1953 (Oct.). Voorstel inzake bouw stuwdam in Grankreek C.A. ten behoeve van afvoer bauxiet uit Nassau- en Lelygebergte; tevens ten behoeve van suppletie van het debiet van het Sara-waterkrachtwerk. Stencil. 
Stichting Planbureau Suriname, 1953 (Oct.). Nota betreffende vergelijkende $k W h$-prijs-berekening op basis NEDECO-en G.T.M.-gegevens. Stencil.

Stichting Planbureau Suriname, 1953 (Oct.). Overzichtskaart Stuwmeer in de Suriname-rivier, schaal I : 100.000 , nr. 00.02.14-W.55.

NEDECO, 1953 (Oct.). Advies inzake Combinatieplan Suriname Rivier. Advisory Memorandum on the Surinam River Combination Plan. 's-Gravenhage, stencil.

NEDECO, 1953 (Oct.). Advies inzake Combinatieplan Suriname Rivier. Rentabiliteitsbeschouwingen Aluminiumindustrie. Den Haag, I6 pp., stencil.

Harza Engineering Company, Consulting Engineers River Projects Chicago, 1954. Project Planning Report Surinam River, including R. Rhoades' Geological Report of Surinam.

Ringma, S. H., 1954 (Jan.). Combination Plan Surinam River. Hydrological Memorandum No. 7. Surinam River, Report for 2nd and 3rd quarters, 1953. Tapanahony, Report for Ist, 2nd and 3rd quarters 1953; etc. Hoorn, 18 pp., I6 bijlagen, stencil.

Stichting Planbureau Suriname, M. H. EKKER, 1954 (Maart-April). Het Brokopondoplan. Maandblad Economische Voorlichting Suriname, I I pp.

Stichting Planbureau Suriname, 1954 (Juni). Vooronderzoek Brokopondoplan. Jaarverslag I953. Paramaribo-'s-Gravenhage, p. 6-9, 23-24, 27-28, stencil.

Ringma, S. H., 1954 (Aug.). Combination Project Surinam River. Hydrology Report No. 8. Surinam River. Gaugings Tapanahony. Hoorn, 19 Pp., 2 I bijlagen, stencil.

Ringma, S. H., 1954 (Sept.). Surinam River Combination Plan. Hydrological Memorandum No. 9. Dam calculations for a combination of 2 and 3 pot lines. Hoorn, ro pp., 3 bijlagen, stencil.

Ekker, M. H., I955 (Jan.). Het Brokopondo plan. Techniek in Praktijk, p. 23-26.

Stichting Planbureau Suriname, 1955 (Mei). Onderzoek Brokopondoplan. Jaarverslag 1954. Paramaribo-'s-Gravenhage, p. 3-7, stencil.

Stichting Planbureau Suriname, H. Teunissen, 1955 (Oct.). Het Brokopondo-project. 7 pp., schetskaart, stencil. (In iets gewijzigde vorm opnieuw uitgegeven in oktober 1956, stencil).

Geuns, L. van, I955 (Oct.). Het Brokopondo-plan en de vestiging van een aluminiumindustrie in Suriname. Economisch-Statistische Berichten (De transatlantische rijksdelen) 40, 2000, p. 906, 907, 909. 
Gids van Suriname, uitgegeven ter gelegenheid van het bezoek van H.M. Koningin Juliana en Z.K.H. Prins Bernhard, 1955 (Oct.-Nov.). (p. 5I : Brokopondo-plan).

Stichting Planbureau Suriname, 1956 (Mei). Onderzoek Brokopondoplan. Jaarverslag 1955. Paramaribo, p. 3-4, stencil.

Anonymus, 1957 (April). Het Brokopondoplan. Bijdrage tot industrialisatie van Suriname. Economische Voorlichting 14, p. 7-8.

Teunissen, H., 1957 (Aug.). The Brokopondo Plan. The Caribbean II, I, p. 12-13.

Ringma, S. H., 1957 (Dec.). Brokopondoplan. Hydrologische Nota No. Io. Suriname rivier periode $1952-1956$. Haarlem, 8 pp., w.o. summary en samenvatting, 47 bijlagen, fotocopie.

Blumer, A., I958 (Juillet). Le projet hydro-électrique de Brokopondo. Industries et Travaux d'Outre-Mer, p. 386-389.

Brokopondo-bureau, $195^{8}$ (Oct.). Streekontwikkelingsplan "Brokopondo."

Brokopondo-bureau, (1958). Licht en kracht uit de oerwouden van Suriname. Vouwblad.

Bureau voor Waterkrachtwerken, Suriname, (1958). Het Brokopondoproject: voorbereidingen en vooruitzichten. 9 pp., stencil.

Suriname Aluminum Company, (1958). Brokopondo. Paramaribo, I6 pp.

Morpurgo, A., I959 (Aug.). Brokopondo. Schakels $S$ 36, p. 3-II. (Brokopondo, een plan en een klank in Suriname. Paramaribo, 1960?. Stencil).

Grondonderzoek voor de bouw van een aarden dam in de Surinamerivier nabij de situatie 'Sara'. LGM Mededelingen Delft 4, 1959, p. I-47, 49-74,

Jonkers, A., 1959 (Aug.). Moderne projecten. Schakels $S$ 36, p. 28-31.

Government Information Service, Surinam, 1959 (Sept.). Facts and figures about Surinam. 20 pp. (p. 12-14: Brokopondo-project).

Harza Engineering Company, Consulting Engineers River Projects Chicago, 1959 (Sept.). Appraisal Survey of Hydroelectric Power Resources in Surinam (vertaling van de samenvatting uit het rapport, I september 1959; 8 pp., stencil).

Rapport van de Adviesraad voor de Herziening van het Tienjarenplan: 'Van 1960 tot 1965', 1959 (Dec.). 212 pp., 4 bijlagen, stencil (p. 40: Brokopondo investeringen; p. 58: Financiering Brokopondo-investeringen).

Brokopondo. Gemeenschappelijke onderneming Suriname-Suralco. Brokopondo. Joint Venture Suriname-Suralco, (1959). 365 pp. 
MeYer, H., 1960 (Mei). Het Brokopondo-plan. De Ingenieur 72, 22, p. A. 309-315.

Anonymus, 1960 (Aug.). Peilen in Suriname. Bauxco Nieuws augustus, p. 4-5.

JoSEPH, W., I960 (Sept.). Over rivierdammen en nog wat. Schakels $S_{40}$, p. $14-18$.

Stichting Planbureau Suriname, 1960 (Dec.). Jaarverslag 1959. Tienjarenplan Suriname. Paramaribo (p. 14, 15: Brokopondoplan).

AdHIN, J. H., 1961 (Juni). Development planning in Surinam in historical perspective (with special reference to the Ten Year Plan). Diss. Groningen, 215 pp. (p. 144-147: The Brokopondo Project).

Stichting Planbureau Suriname, 1962 (Juni). Suriname. Beknopte beschrijving van het land, de bevolking, de staatkundige, sociale en economische struktuur. 84 pp., 8 bijlagen, stencil (p. 75-78: De ontwikkeling van het waterkrachtpotentieel van Suriname).

Suralco, Public Relations, 1962 (Sept.). Het Brokopondo Projekt, een gemeenschappelijke onderneming van Suriname en Suralco. Technische gegevens. Paramaribo, vouwblad.

Borten, J. R., 1963-1964. Analyse van de neerslag en de verdamping in Suriname. Bureau Landelijke Opbouw. Verslagen en Rapporten van de Stichting Planbureau Suriname, Ministerie van Algemene Zaken. 3 Delen.

Anonymus, 1964 (Maart). Onderzoek waterkrachtontwikkeling Tapanahony-rivier wordt geintensiveerd. Surinaams Nieuws, Kabinet Gevolmachtigde Minister van Suriname, 's-Gravenhage, 14, 12, p. I-2.

- Hillen, D., Suralco, 1964 (Maart). Bauxiet vandaag, aluminium in 1965. Baas boven baas (Nederlands Instituut voor Efficiency) 14, 3, p. 37-4I.

Roethof, H. J., I964 (Maart), Oude en nieuwe wereld (Het Brokopondoprojekt in Suriname). Schakels $S_{58}$, p. 17-21.

- BAncke, CssF, Pater Ed., 1964 (Juli). Transmigratie van Bosnegers (Het

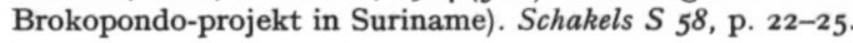

- Roethof, H. J., 1964 (Sept.). Nieuwe plannen voor elektriciteitsopwekking door waterkracht (Het Brokopondo-projekt in Suriname). Schakels $S_{58}$, p. 26-28 (32).

Consen, Henk, 1964 (Oct.). Afobaka-stuwdam (Het Brokopondo-projekt in Suriname). Schakels $S_{58}$, p. I-6.

Consen, Henk, 1964 (Oct.). Het stuwmeer (Het Brokopondo-projekt in Suriname). Schakels $S_{58}$, p. 7-1I. 
Consen, Henk, 1964 (Oct.). Voordelen (Het Brokopondo-projekt in Suriname). Schakels $S_{58}$, p. 12-16.

(Suralco), I965 (Febr.). Reportage uit Suriname. Brokopondo-projekt nadert voltooiing. De Nederlandse Industrie (Verbond van Nederlandsche Werkgevers) 4, p. 100-103.

Roethof, H. J., I965 (April). Electrische energie en waterbeheersing (Brokopondo-stuwmeer in Suriname). Schakels $S$ 6o, p. 26-28.

- Hulsbos, L., I965 (Juni). Voorgeschiedenis en vooronderzoek (Brokopondo-stuwmeer in Suriname). Schakels $S$ 6o, p. 29-32.

Hillen, D. \& Achterhof, E. Th., I965 (Juli). Het Brokopondo-Project. Polytechnisch tijdschrift (Nederlands Instituut van Register-Ingenieurs en Afgestudeerden van Hogere Technische Scholen - NIRIA), B-editie, 20, 14, p. $564 \mathrm{~B}-570 \mathrm{~B} ; 1_{5}$, p. $609 \mathrm{~B}-61_{3} \mathrm{~B}$.

(Suralco), 1965 (Dec.). Reportage uit Suriname. H. M. de Koningin opende aluminiumbedrijf te Paranam. Produktiecapaciteit 8oo.ooo ton aluinaarde en 60.000 ton blokaluminium. De Nederlandse Industrie (Verbond van Nederlandsche Werkgevers) 23, p. 872-874.

Stichting Planbureau Suriname, 1965. Nationaal Ontwikkelingsplan Suri- name, deel 2 (p. 269-277: Het Distrikt Brokopondo; p. 305-332: Het hydrologisch plan).

Suriname Aluminum Company, 1966. Dit is de Suralco, Paramaribo, $3^{\text {I }}$ pp. (p. 12-13; Energie uit waterkracht; p. 22: Afobaka).

Suralco, 1966 (Dec.). 50 jaar samen met Suriname. Bauxco Nieuws I7, I2 (p. 24-29: Brokopondo).

VROoN, L. J., I967 (April). Enige aspecten van de aluminiumindustrie, I, II. Economisch-Statistische Berichten 52, 2588, 2589, p. 385-387, 419-42I.

Memorandum inzake de informatie van het nieuwe kabinet voor de regeringsperiode 1967/1971, 1967 (April). Hoofdstuk III, p. 16-37: Waterkracht.

Ministerie van Openbare Werken en Verkeer, Suriname, Waterloopkundige Afdeling, 1965 (Okt.), 1967 (Maart, Juli). Jaarboek der waterhoogten, afvoeren en zoutgehalte rivierwater 1961 (I965), 1962 (deel I en 2, I967), 1963 (deel I en 2, 1967).

KrUiJer, G. J., 1968. Suriname en zijn buren. Landen in ontwikkeling. Meppel, I968, 4de druk (p. 246-252: Het Brokopondoproject en het belang van de bauxiet voor Suriname).

Ministerie van Bouwwerken, Verkeer en Waterstaat. Waterloopkundige Afdeling, 1968 (Maart). Jaarboek der waterhoogten, afvoeren en zoutgehalte rivierwater 1964 . 
Ministerie van Bouwwerken, Verkeer en Waterstaat. Waterloopkundige Afdeling, 1968 (Aug.). Jaarboek der waterhoogten, afvoeren en samenstelling rivierwater 1965 .

Centraal Bureau Luchtkartering, 1968. (Topografische kaart van) Suriname, schaal I : 500.000 . Hoogtelijnen interval $=250 \mathrm{~m}$. Blad I, II (3e druk), III, IV (2e druk).

Bureau voor Waterkrachtwerken, Suriname, 1968. Overzichtskaart van bestaande en geprojecteerde waterkrachtwerken in Suriname, schaal I : 500.00o (met de hand gekleurd).

Bureau voor Waterkrachtwerken, Suriname, 1968. (Overzichtskaart) Irrigatie Plan West Suriname, schaal $I: 250.000$. Nr. 04.01-50 (met de hand gekleurd).

Bureau voor Waterkrachtwerken, Suriname, 1968. (Overzichtskaart) Kabalebo Projekt, Project Area, schaal I : 200.00o. Nr. 04.01.53; 6-8-1968 (met de hand gekleurd).

Suralco, 1969 (Maart). Beknopte gegevens Suriname Aluminum Company. 5 pp., stencil.

\section{b. NATUURWETENSCHAPPELIJKE, MEDISCHE EN SOCIOLOGISCHE ASPECTEN \\ (in chronologische volgorde)}

Natuurwetenschappelijke Studiekring voor Suriname en de Nederlandse Antillen, 1953 (Maart). Beschouwingen naar aanleiding van het Combinatieplan Van Blommestein (c.q. Brokopondo-plan) voor de Suriname-rivier. Nota voor de Surinaamse regering, stencil.

Union Internationale pour la Protection de la Nature, 1954. Procès-verbaux et rapports de la réunion technique tenue à Caracas, du 3 au 9 septembre 1952. (p. 63-85, 120-142, 173-192, 209-210, 215-216, 221-222, 229-378: La energía hidroeléctrica y la protección de la naturaleza).

Brokopondo-Raad, Subcommissie voor bestudering van de natuurwetenschappelijke consequenties, D. C. GeIJSkes, I954 (Jan.). Programma voor het onderzoek van de naturwetenschappelijke consequenties ten aanzien van het Brokopondo-plan. Stuk no. 54-8, 3 pp., getypt.

- Brokopondo-Raad, Subcommissie voor bestudering van de verplaatsing van de bevolking uit het stuwmeergebied, J. Michels, I954 (Jan.). Verplaatsing bevolking. Stuk no. 54-9, 3 pp., getypt.

Schulz, J. P., 1954 (Oct.). Vergelijkend literatuuronderzoek inzake de ecologische consequenties van het "Combinatie-Plan Suriname Rivier". Natuurwetenschappelijke Studiekring voor Suriname en de Nederlandse Antillen, Utrecht, 124 pp., 3 bijlagen. 
HAAN, J. H. DE, 1955. Ecologisch onderzoek ten behoeve van het Brokopondoplan in Suriname. De West-Indische Gids 36, p. 18-31.

Gonggryp, J. W., 1955. Some remarks on the Brokopondo Project. Vox Guyanae 1,6 , p. $145^{-1} 48$.

International Union for the Protection of Nature, 1955. Hydro-Electricity and Nature Protection. Stating the case. Hydro-électricité et Protection de la Nature. Une confrontation. Pro Natura Series, Vol. II, Bruxelles.

Westermann, J. H., 1956 (Febr.). Een korte beschouwing over het Brokopondo-plan, mede gezien tegen de achtergrond van een Amerikaans oordeel over de relatie tussen de opwekking van hydro-electrische energie en de conservering van vervangbare natuurlijke hulpbronnen. Natuurwetenschappelijke Studiekring voor Suriname en de Nederlandse Antillen, Utrecht, I6 pp., stencil.

GongGryp, J. W., 1956 (Maart). Can firewood in the Guianas be a source of power for the production of aluminum? Paramaribo, 4 pp., stencil.

Wagenaar Hummelinck, P., I958. De Brokopondo-overeenkomst geparafeerd. Vakblad voor Biologen 38, p. 28-29.

Michels, J., $195^{8}$ (Dec.). Transmigratie Saramakkaners en Aukaners Boven-Suriname. Paramaribo, 3I pp., I bijlage, I schetskaart, stencil.

DuYfF, J. W., 1959. Nota betreffende de technisch-hygiënische problemen in verband met de uitvoering van het stuwmeerproject (aan de Minister van Volksgezondheid, Suriname). 4 pp., getypt.

Bureau Landelijke Opbouw, 1960 (April). Prae-advies inzake het Streekplan Brokopondo. Rapporten en verslagen van het Departement van Opbouw, Paramaribo, 40 pp., 3 bijlagen, stencil.

ThIEL, P. H. van, I96o (Dec.). De malariaproblematiek in verband met de uitvoering van het Brokopondo-project. Stichting Surinaams-Nederlands Instituut voor de Volksgezondheid in Suriname, 's-Gravenhage, Leiden, 83 pp. incl. literatuurlijst, 6 schetskaarten.

WagenaAR Hummelinck, P., r961. Het Brokopondoplan. Vakblad voor Biologen 4I, p. 174-179.

ThIEL, P. H. VAN, 196I (Dec.). De kans op infectie met filaria en schistosoma in verband met de uitvoering van het Brokopondo-project. Stichting Surinaams-Nederlands Instituut voor de Volksgezondheid in Suriname, 's-Gravenhage, Leiden, 29 pp. incl. literatuurlijst.

- Hoedeman, J. J., 1962 (Jan.). Voor en tegen van het Brokopondo-stuwmeer. Elseviers Maandblad De Kern 32, p. (28) 31-35. 
ThIEL, P. H. van, 1962. Malaria problems arising from the construction of a reservoir in the interior of Surinam. Tropical and Geographical Medicine 14. p. $259-278$ (paper read at the combined meeting of the Dutch and the Belgian Societies of Tropical Medicine, Noordwijk, June, 196r; based on a report to the Netherlands-Surinam Foundation for Public Health in Surinam. Received October 2oth, 196r).

Asin, H. R. G., 1962 (Juni). De invloed van het contact tussen stads- en boslandbevolking op de epidemiologie van parasitaire darminfecties, een prognose bij de bouw van een stuwdam in de Surinamerivier. Leiden, proefschrift, $96 \mathrm{pp}$.

Asin, H. R. G. \& Thiel, P. H. van, 1963. An intestinal protozoa in the urban and bushland population in Surinam. Tropical and Geographical Medicine 15, p. 108-120. (p. 110-112: Examination in the inhabitants of the Brokopondo Reservoir area).

Asin, H. R. G. \& ThIEL, P. H. van, 1963. On the distribution of intestinal helminths in the urban and bushland population in Surinam. Tropical and Geographical Medicine 15, p. 257-267. (p. 257-260, 263-264: Examination of the people in the Brokopondo Reservoir area).

Anonymus, 1963 (Dec.). Dieren in het Brokopondo-stuwmeer. Orgaan van de Vereniging voor Dierenbescherming, Paramaribo, p. 2-5.

Michels, J., 1965 (Maart). Operation Gwamba. Schakels S 6o, p. 18-24.

RoEthof, H. J., 1965 (Dec. 1964). Dieren in nood (Brokopondo-stuwmeer in Suriname). Schakels $S 60$, p. 24-25.

Edgcomb, GABRIElle, 1965 (Sept.). Man-made lakes: a selected guide to the literature. An aid to planning multi-disciplinary research on new African reservoirs. Compiled for the Africa Science Board in cooperation with the African Section of the Library of Congress. National Academy of Sciences, National Research Council, Washington D.C.; 98 pp., mimeograph.

Ghana Academy of Sciences, 1966. International Symposium on Man-Made Lakes, November 21-24.

Smith, J. Robert, 1966. Surinam animal rescue. Natural History, Journal Am. Mus. Natural History, 75, I, p. 24-29.

GONGGRYP, J. W., I966 (Juni). Watervulling en waterverliezen van het Brokopondo-stuwmeer. Nota voor de Natuurwetenschappelijke Studiekring voor Suriname en de Nederlandse Antillen, Breda, 7 pp., 2 tab., stencil.

WALSH, JOHN, with ROBERT GANNON, 1967. Time is short and the water rises (Operation Gwamba: the story of the rescue of 10,000 animals from certain death in a South American rain forest). London, 224 pp. 
GongGryP, J. W., 1967 (Juli, Aug.). Over energievoorziening en waterkrachtpotentieel van Suriname I, II. Interim nota voor de Studiekring, Breda, II pp.

GoNGGRYP, J. W., 1968 (Feb.). Waarom is het Brokopondo-stuwmeer thans niet vol? Wanneer zal het in de toekomst vol lopen? Interim nota voor de Studiekring, Breda, 7 pp.

GoNGGRYP, J. W., 1968 (Maart). Taxatie van het waterverlies van het stuwmeer in 1967 . Interim nota voor de Studiekring, Breda, 3 pp.

GoNGGRYP, J. W., I968 (April). Voorlopige gegevens tot nadere berekening van de capaciteit van het Brokopondo-stuwmeer. Interim nota voor de Studiekring, Breda, 4 pp.

GongGryp, J. W., 1968 (April). Gegevens tot berekening van de waterhuishouding van het Brokopondo-stuwmeer. Interim nota voor de Studiekring, Breda, 5 pp.

GongGryp, J. W., I968 (Dec.). Opmerkingen betreffende het Brokopondostuwmeer in Suriname. Nota voor de Studiekring, Breda, 8 pp., I bijl., stencil.

O'Reilly Sternberg, Hilgard, 1968. Man and environmental change in South America. Biogeography and Ecology of South America I, The Hague, p. 4r3-445, 3 figs. (p. 432: Brokopondo). Center for Latin American Studies, Institute of International Studies, University of California, Berkeley, California, Reprint No. 310.

GoNGgRYP, J. W., 1969 (Feb.). Nadere opmerkingen betreffende het Brokopondo-stuwmeer in Suriname. Interim nota voor de Studiekring, Breda, 4 pp.

Anonymus, 1969 (Sept.). Jachtgebied Brokopondo-areaal binnenkort weer open. Suriname. Feiten en Cijfers 9 (Stichting tot bevordering van investeringen in Suriname, Den Haag).

LAgler, Karl F. (editor), 1969. Man-made lakes. Planning and development. FAO, Rome.

\section{c. HET NATUURWETENSCHAPPELIJK ONDERZOEK, I $962-$ I 969 \\ (in alfabetische volgorde)}

Bennetr, F. D. \& ZWÖLFER, H., 1968. Report on a survey of the insects and mites associated with Water Hyacinth, Eichhornia crassipes, in northern South America, undertaken in February-March 1968 . Commonwealth Institute of Biological Control, Trinidad, 29 pp., mimeograph. 
Boeseman, M., r968 (Dec.). The genus Hypostomus Lacépède, r 803, and its Surinam representatives (Siluriformes, Loricariidae). Zoologische Verhandelingen (Rijksmuseum van Natuurlijke Historie, Leiden) 99, 89 pp., 18 plates.

Boeseman, M., 1969. Additional new species of Hypostomus Lacépède, I803, from Surinam; with remarks on the apparent 'gymnorhynchuscomplex' (Siluriformes, Loricariidae). Beaufortia (Zoological Museum, University of Amsterdam) 16, 215, p. 119-136.

Demoulin, Georges, 1966. Contribution à l'étude des Ephéméroptères du Surinam. Bulletin Institut Royal des Sciences Naturelles de Belgique 42, 37 , p. $\mathbf{I}-\mathbf{2 2}$.

DONSElAAR, J. VAN, 1968. Water and marsh plants in the artificial Brokopondo Lake (Surinam, S. America) during the first three years of its existence. Mededelingen Botanisch Museum en Herbarium Rijksuniversiteit Utrecht 299; Acta Botanica Neerlandica 17, p. 183-196.

DonselaAR, J. van, 1969. On the distribution and ecology of Ceratopteris in Surinam. American Fern Journal 59, 1 , p. 3-8.

DonselaAr, J. van, 1970. Floristic and ecological data on the lianes of the Brokopondo District, Surinam. Acta Botanica Neerlandica I9, p. 287-296.

Donselaar, J. van \& Westra, L. Y. Th., I968. De epiphytentuintjes van het Brokopondo-stuwmeer. Orchideeën (Nederlandse Orchideeën Vereniging) 30 (Nieuwe Serie), 2, p. 36-4I.

Foundation for Scientific Research in Surinam and the Netherlands Antilles, 1964-1969. Biological Brokopondo Research Project, Surinam. Progress Reports, Part I, 1963-1964, p. I-89; II, 1965, p. 90-14I ; III, 1965-1966, p. $142-207 ; I V$, 1967-1969, p. 208-265.

Boeseman, M., Ichthyological and other observations, $I$.

DonselaAr, J. van, Botanical observations, $I, I I, I I I, I V$.

GeIJSKES, D. C., General remarks, $I$.

HeIDE, J. VAN DER, Hydrobiological observations, $I, I I, I I I$.

LeentvaAR, P., Hydrobiological observations, $I, I V$.

MeEs, G. F., Ichthyological and other zoological observations, $I I I$.

NijSsEn, H., Ichthyological observations, $I I I, I V$.

NiJSSEN-MEYeR, J., Hydrobiological observations, $I V$.

Heide, J. van DER, 1966. Het stuwmeeronderzoek in Suriname. Tijdschrift Kon. Ned. Aardrijkskundig Gen. 83, 2, p. 173-180.

HEIDE, J. VAN DER, 1967. Hydrobiology of the artificial Brokopondo lake, Surinam. Netherlands Foundation for the Advancement of Tropical Research (WOTRO). Report for the Year 1966, p. 46-49.

J(ONKER), F. P., 1966. Het natuurwetenschappelijk Stuwmeer-onderzoek in Suriname. Solaire Reflexen (Rijksuniversiteit Utrecht) I2, 9, p. 2-3. 
LeentvaAR, P., 1964. Biologisch onderzoek in het Brokopondo-meer. Voordracht, 21 november 1964, 33ste Algemene Vergadering Natuurwetenschappelijke Studiekring voor Suriname en de Nederlandse Antillen. Verslag, p. 4-6, stencil.

LeentvaAR, P., I965 (Febr.). De biologie van de Suriname-rivier vóór de gereedkoming van de Afobaka-stuwdam. Schakels $S 60$ (Kabinet Vice Minister-President, 's-Gravenhage), p. I-5.

LeentvaAr, P., 1965 (Febr.). De biologie van het Van Blommestein-stuwmeer. Schakels $S$ 6o, p. 6-17.

LeentvaAr, P., I965. De biologie van het Brokopondo stuwmeer in Suriname I-3. Delveaard (Deventer Landbouwers Vereniging en Reunisten Vereniging) 3,4 , p. 9-1I; 5, p. 5-6; 6, p. 23-25.

Leentvaar, P., 1965. Ervaringen in Suriname. Het Aquarium 36, 6, p. 126-132.

Leentraar, P., 1965 (Sept.). Iets over rivieren en kreken in Suriname. De Levende Natuur, p. 224-232.

Leentvaar, P., I966. VI. Artificial reservoirs. The Brokopondo Lake in Surinam. Verh. Internationale Verein für Limnologie, Stuttgart I6, p. 680684 .

LeentvaAr, P., 1966. The Brokopondo Research Project, Surinam. Manmade Lakes. Symposium Institute of Biology, London, p. 33-42.

LeentvaAr, P., I967. The artificial Brokopondo Lake of the Suriname river. Its biological implications. Atas do Simpósio sobre a Biota Amazónica 3, (Limnologia), p. 127-140.

LeentvaAR, P., 1968. Wetenschappelijk onderzoek op het stuwmeer. Bauxco Nieuws, Suriname, 18,7, p. 4-7.

LeEnTVAaR, P., 1968. Verslag van het hydrobiologisch onderzoek van het Brokopondo-stuwmeer in april I968; 16 pp., tab. 9 graf., stencil. (cf. Hydrobiol. research in April 1968, Progr. Rep. IV, p. 249-26r).

Lowe-McConnell, R. H., 1966. Man-made Lakes. Proceedings of a Symposium held at the Royal Geographical Society, London, on 30 September and I October 1965. Symposia of the Institute of Biology No. I5. Academic Press London and New York, 218 pp.

Maatschappij voor Wetenschappelijk Onderzoek in de Tropen (TreubMaatschappij), 1970. Notulen zeven en zeventigste Algemene Vergadering, 7 juni $x 968$. Het natuurwetenschappelijk stuwmeeronderzoek Suriname, p. 6-I5.

GeIJSKES, D. C., Het Brokopondo-onderzoek, p. 6-8.

HEIDE, J. VAN DER, Hydrobiologisch onderzoek, p. 8-Io. 
Boeseman, M., Ichthyologisch onderzoek, p. I0-I3.

DONSElaAR, J. vaN, Botanisch onderzoek, p. $13^{-15}$

MeEs, G. F., 1967. Freshwater fishes of Suriname: the genus Heptapterus (Pimelodidae). Zoologische Mededelingen (Rijksmuseum van Natuurlijke Historie, Leiden) 42, 20, p. 215-229.

Noelmans, P. L. J., 1969 (Jan.). Oecologie en verspreiding van enkele zeldzame fauna-elementen in Suriname. Ingenieursscriptie, Wageningen, stencil (p. I-4I: zeekoe).

Nijssen, H., 1970. Revision of the Surinam catfishes of the genus Corydoras Lacépède, 1803 (Pisces, Siluriformes, Callichthyidae). Beaufortia 18 , 230, $75+2$ pp. (tevens dissertatie).

NiJssen, H. \& ISBRÜCKER, I. J. H., I967. Notes on the Guiana species of Corydoras Lacépède, 1803 , with descriptions of seven new species and designation of a neotype for Corydoras punctatus (Bloch, 1794) - (Pisces, Cypriniformes, Callichthyidae). Zoologische Mededelingen 42, 5, p. 21-50 (5 plates).

Nijssen, H. \& Isbrücker, I. J. H., 1968. Gymnotus carapo and G. anguillaris (syn.: G. coropinae), two often confused species of gymnotid fishes (Pisces, Cypriniformes). Beaufortia 15, 203, p. 161-168.

Suralco, 1964. Stuwmeer onderzoek. Bauxco Nieuws I4, 5, p. 4-8.

Suralco, 1965. De bestrijding van de waterhyacinth (op het stuwmeer). Bauxco Nieuws 16,3 , p. 4-8.

WEERT, R. VAN DER \& KAMERLING, G. E., I968 (Dec.). Evapotranspiratie van waterhyacinth (Bodemfysisch en agrohydrologisch onderzoek). Intern rapport no. 2II, Landbouwproefstation Paramaribo; 49 pp., incl. tab. en fotogr., excl. 5 graf., 2 figs., stencil. 